
Hettertec Afbew Thatey

afuesint

griens Whife Softor -

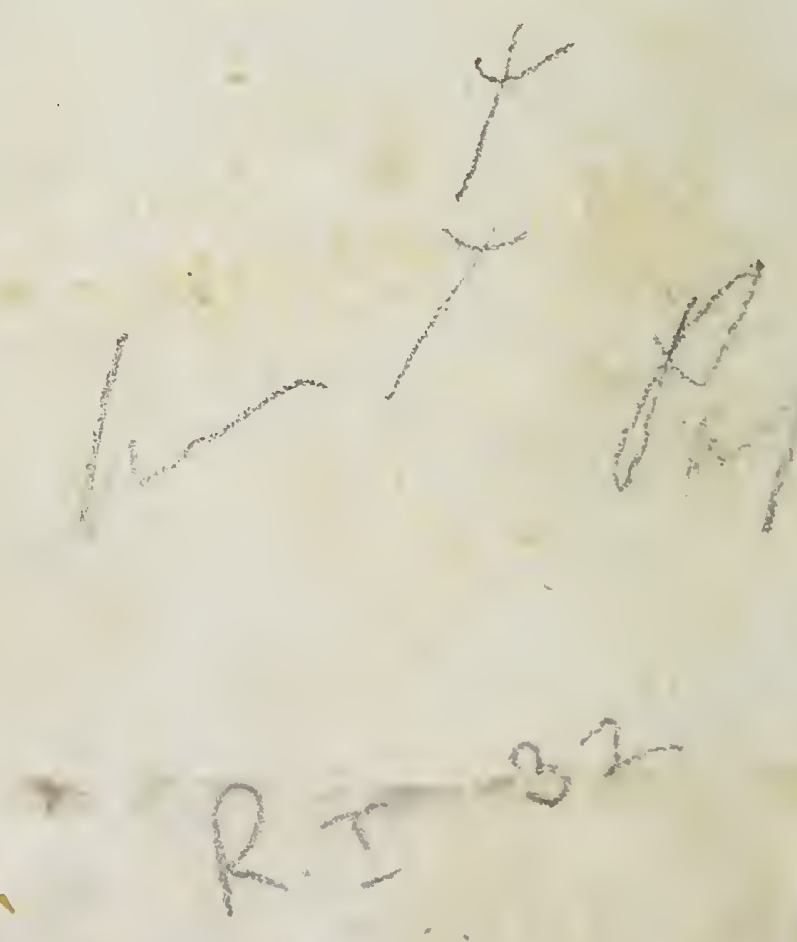



Digitized by the Internet Archive in 2016 


\section{A COMPANION}

TO THE

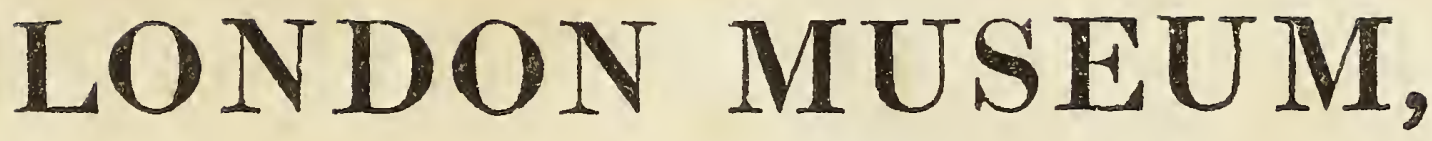

AND

PANTHERION,

CONTAINING

A BRIEF DESCRIPTION

OF UPWARDS OF

FIFTEEN THOUSAND NATURAL AND FOREIGN

CURIOSITIES, AN'TIQUITIES,

AND

PRODUCTIONS OF THE FINE ARTS:

NOW OPEN FOR PUBLIC INSPECTION IN

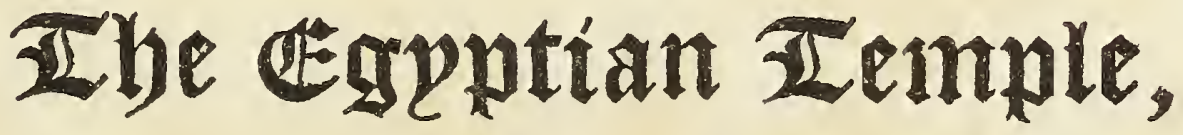

PICCADILLY, LONDON,

By WILLIAM BULLOCK,

Fiellow of the Linncan Society of London, of the Werneriun Society of Natural Hisiory of Edinburgh, and Honorary Menber of the Dublin Society.

O Nature! how in every charm supreme!

Whose vot'ries feast on raptures ever new,

0 ! for the voice and fire of Seraphim,

To sing thy glories with devotion due?

BEATTIE.

THE SEVENTEENTH EDITION.

\section{LONDON:}

PRINTED FOR THE PROPRIETOR, BY WHITTINGHAM AND ROWLAND, GOSWELT STREET. 
The full value given for rare and uncommon 2uadrupeds, Birds, Fishes, Reptiles, Shells, Old Paintings, Carvings on Wood or Ivory, Stained Glass, ancient and foreign Arms and Armour, or any uncommon production of Art or Nature. 


\section{ADDRESS.}

Mr. BULLOCK respectfully begs leave to solicit the attention and patronage of the Nobility, Gentry, and the Public, to an Establishment for the advancement of the Science of Natural History, which in magnitude and expense, he presumes, is unparalleled, as the work of an individual.

The very flattering and general approbation which honoured the Exhibition of his Museum, on its opening in a temporary situation in London, was a convincing proof that his future efforts for the extension and improvement of the Collection would be duly appreciated. His exertions to obtain articles of rarity and interest, have, therefore been unceasing. In most departments, the subjects have been doubled in number; the specimens are choice, in the highest possible preservation, and are arranged according to the Linnæan system. They consist of upwards of Fifteen Thousand species of Quadrupeds, Birds, Reptiles, Fishes, Insects, Shells, Corals, \&c. \&c. collected during 
twenty years of unwearied application, and at an expense exceeding thirty thousand pounds.

In adapting the Edifice which Mr. Bullock has just completed for the present collection, by displaying it advantageously for the Study of the Naturalist, the Instruction of the Curious, and the Amusement of those who are delighted in viewing the Beauties of Nature, or the Curiosities of Art, he has endeavoured to render it worthy of the British Metropolis, whilst he has also provided the means for enlargement, as future additions shall accumulate.

One department of the Museum (the Pantherion) completed with much labour and great expence, is entirely novel, and presents a scene altogether grand and interesting. Various animals, as the lofty Giraffa, the Lion, the Elephant, the Rhinoceros, \&c. are exhibited as ranging in their native wilds and forests; whilst exact Models, both in figure and colour, of the rarest and most luxuriant Plants from every clime, give all the appearance of reality; the whole being assisted with a panoramic effect of distance and appropriate scenery, affording a beautiful illustration of the luxuriance of a torrid clime.

The Museums of France have been enriched with the spoils of nearly the whole Continent, and 
the Gallery of the Louvre contains more treasure in Painting and Sculpture than perhaps will ever again be amassed in one Collection. But though her active and persevering Ruler, desirous of making his capital the centre of every attraction, has contributed to the Museum Naturale, every specimen of Natural History which in the present state of the Continent could be procured, our unrivalled Navy, and the extension of our Colonies throughout the habitable world, present such advantages to this country, that the writer feels confident, that if his exertions are seconded by the Public as they have hitherto been, he will very shortly be enabled to make a Collection of Natural History far surpassing any thing of the kind at present in existence; and he pledges himself to exert his utmost power in accomplishing this important work.

To the numerous Royal, Noble, and liberal Contributors to his Museum, by whose kindness his Collection has been enriched by so many valuable articles, which could not have been procured by pecuniary means, Mr. Bullock returns unfeigned thanks.

When the information and delight which may be derived from this Exhibition, especially by the rising generation, are considered, the great sum expended in forming it, and the erection of the present large and commodious building for its re- 
ception, the Proprietor trusts that the terms on which the Public are admitted, will be thought moderate and approved of.

Admission to each Exhibition, One Shilling.Annual Ticket, not transferable, £1.1s.-Subscriber for Life, $£ 10$. 10 s.

\section{Museum, Piccadilly,}

Warch 28, 1813. 


\section{NA MES}

or $\mathrm{xta}$

\section{LADIES AND GENTLEMEN}

WHO HAVE PRESENTED

\section{CURIOSITIES}

\section{TO

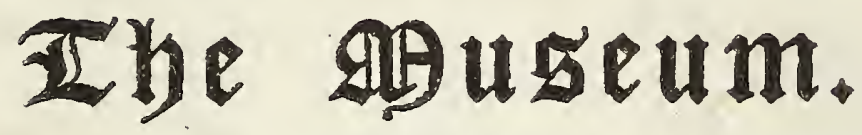

HER MAJESTY.

HIS RUYAL, HIGHNESS

THE PRINCE REGENT。

HER ROYAL HIGHNESS THE

PRINCESS CHARLOTTE OF COBOURG.

HER ROYAL HIGHNESS

'THE PRINCESS ELIZABETH.

THEIR ROYAL HIGHNESSES THE

DUKE AND DUCHESS OF YORK.

Athol, His Grace the Duke of ......

Adams, Mr. R......................... $\left\{\begin{array}{l}\text { Charlotte-str.Fitzroy. } \\ \text { square }\end{array}\right.$

Adams, W. Esq......................... King'sRoad, Sloane-sq.

Aiton, Wm. Esq. F. L.S.............. Kere

Allen, Thomas, Esq. F. R.S.E..... Edinburgh

Anderson, Mr. F. L.S

Ashton, N. Esq.

Liverpool

Balfour, Captain Isle of Shapinsa in

Banks, Lady.

Banks, Sir Joseph Orkney

Barclay, Dr.

London

Barrow, Captain.

Edinburgh

Beaufoy, Mark, Esq... Liverpool Mount-str. Grosw.-sq. 
Bedford, His Grace the Duke of...

Birchall, S. Esq.......................... Leeds

Blackburn, J. Esq. M. P............... Hale

Blane, Lady.

Blandford, Marchioness of .

Bligh, late Mrs...

Bligh, Vice Admiral.

Blois, Sir Charles.

Blundell, Henry, Esq.......................

Blundell, Bryan, Esq....................

Bolton, John, Esq..........................

Bolton, Mrs.

Bootle, W. Esq. M. P.

Bowden, Joshua, Esq.

Boscawen, Hon. Mrs.....................

Brettargh, Mr. J

Bright,

, Esq.

Broadbent, Mr

Brogden, H. Esq. F. L. S..

Bruce, Miss.

Buckingham, Marquis of a..............

Castlereagh, Lady.

Castlereagh, Lord.

Cavan, Earl of.

Caldwell, Charles, Esq.

Campbell, Captain..........................

Chatham, Countess of.

Chichester, Earl of .

Clarke, Captain...............................

Clarke, Rev. Dr. A.....................

Coltman, Dr.

Comyns, W. Esq.

Cox, Lady Hippesley.....

Courtown, Lord....

Cranch, Mr. T.

Crawford, Captain J. Couts............

Cullum, Sir Thomas, Bart.............

Cullum, Rev. Mr....

Currie, Mrs.

Dadford, Thomas, Esq

Dalrymple, Lieutenant-General...

Daniel, ._, Esq. R.A. and F.A.S.

Darnley, Earl of.

Dartmouth, Countess of ................

Davies, (late) Gen

Deanand Chapter of Christ-Church

Durham Place

Cockfield Hall, Suffolk Ince Hall

Liverpool

Liverpool

Liverpool

Latham House

Liverpool

St. James's Palace

Trafford Hall

Bristol

Hull

Clapham

Demerara

Lirerpool

Liverpool

Liverpool

London

Liverpool

Darolish, near Exeter

Kingsbridge, Devon

H.M. S. Modesté

Bury St. Edmunds

Bury St. Edmunds

Liverpool

Wolverhampion

Blackheath

Oxford. 
Directors of the Blue-coat School..

Drake, J. Esq.

Dublin, Royal Society of.

Dundas, Lord.

Durham, Bishop of.

Durrazzo, Marquiss...

Edmonson, J $r$

Edmonson, Mr. L

Edwards, Rev. Mr.

Edwards, Mr. S. F.L.S

Egerton, Hon. Miss

Ellis, Edward, Esq....

Essex, Countess of.....

Fawkes, Walter, Esq

Fisher, Lieut. R. N.

Foljambe, F.F.Esq

Forbes, William, Esq.................

Ford, Mrs.

Francillon, John, Esq. F.L.S.

Frazier, Mr. F.L.S.

Gage, Lord

Gascoyne, Mrs. I.

Gerldes, J. Esq

Geddes, Mr. G.

Gordon, Col

Gordon, - Esq...........................

Graham, Col.

Green, (late) Mr.

Gurney, (late) B. Esq

Haldane, Lieut. Col.

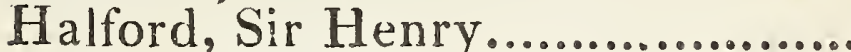

Halford, Lady.

Hamilton, Rev. G.

Harcourt, Lady

Hardy, James, Esq.

Harland, Sir Robert, Bart

Harrington, Lady I.

Harrison, A. Esq. F. L.S

Harper, William, Esq.

Haywood, -, Esq. F.L.S.

Hanson, _- Esq....

Henley, H. H. Esq. F.L.S.

Heward, Mr.

Holland, Lord.
Liverpool

Great Berkhamstead

\section{Genoa}

Lerwick, Zetland

Isle of Unst

Lynn

Brompton

Windsor Castle

Strensal Hall, York

Farnley Hall

Liverpool

Osberton,nearWorksop

Liverpool

Upper Brook-street

Norfolk-street

Chelsea

Childrwall Hall

Glasgore

Stromness

Chelsea

Glasgow

Litchfield

Norwich

Croydon

Isle of Hoy (Orkneys)

Glasgow

Westminster

Liverpool

Collingham, near Hull

s Rookery, Woodford, Essex

S Sandringham Hall, Norfolk 
Holswilders, D. Esq......................

Horrier, Col................................ .

Hoy, M. Esq

Hoy, John, Esq.

Humphries, Mr. G.

Hunter, Admiral.

Irby, J. Esq.

James, Mrs.

Jamieson, Sir J

Jennings, C. Esq.

Johnson, James, Esq. F. A.S.

Johnson, Robert, Esq...................

Johnson, Col.

Kilderbee, S. Esq.

Knox, Mr.

Koster, J. T. Esq.

Lane, Mrs.

Laurence, Charles, Esq...

Lambert, A. B. Esq. V.P. L.S.

Leach, Dr. W. E. F.L.S.

Leathes, Rev. G. R. F.L.S.

Lefevere, Mrs. Shaw.

Leger, Hon. Col. St...

Lettsom, Dr. F.L.S

Leicester, Sir John, Bart.

Liverpool, Earl and Countess of ...

Lowndes, Mr.

Macdonald, Angus, Esq.... ..........

M'Dougal, Dr.

Mackenzie, Sir George, Bart.

M`Nalley, L. Esq.

M·Neil, Lieut.-General.

Madden,

Mawe, Mrs

Middleton, W.T. Esq..

Miller, Captain.

Mitford, Miss

Moira, Earl of..

Montagu, Col. F. L.S

Moodie, Major.

Moore, Henry Glover, Esq...........

Mulgrave, Lord

Munro, Dr.

Museum of Paris, Directors of the
Surinam

Mills Park, Somersę.

Gordon Castle, N.B. London

$\{$ Britwell House, Maidenhead

St. Lucia

London

Chelsea

Bristol

Liverpool

Calcutta

Campsey Ash, Suffolk

Chichester

Liverpool

3, Fenchurch-street

Liverpool

Grosvenor-street

Spring Gardens

Dublin

Tabley

Liverpool

Pall Mall Court

Glasgow

\section{Dublin}

Bath

Dublin

Strand

S Shrubland Park,

Suffolk

Hull.

Clifford-street

Knowle House, Devcn Walls, Isle of Hoy

Liverpool

Edinburgh 
Neilson, William, Esq

Niel, Patrick, Esq. F.L.S

Nixon, Mr.

Nugent, Dr

Ogle, Rev. Mr

Parke, W. Esq.

Parry, Henry, Esq.......................

Pasco, Captain, R. N.................

Perth, Lady

Phillips, Leigh, Esq. F. L. S........

Pious VII, His Holiness................

Plaisted, Mr.

Pollock, Mrs.

Polito, Mr. S.

Powell, Captain.

Powell, Mrs

Price, Major

Puleston, Col. Emral....................

Ray, Mr.

Ranier, Captain, R. N

Read, (late) Lady.

Reeve, John, Esq...

Rendlesham, Lord.......................

Roach, Captain.

Robinson, Col. M. P..

Roscoe, William, Esq. F.L.S......

Ross, G. Esq.............................

Rowley, Lady

Salt, Jonathan, Esq. F. L. S..........

Sandbach, Mr.

Sartorius, Mr.

Salisbury, Bishop of .

Scott, Corse, Esq.

Scot, Walter, Esq.

Seaforth, Lord

Sharp, Thomas, Esq.....................

Sharp, Rev. Mr.

Sheffield, Lord

Sheridan, Thomas, Esq.................

Smith, Dr. J. E. P. L. S.

Smith, William, Esq

Smyth, Rev. John

Somerscales, Mr.

Sowerby, Mr.F.L.S.

Stainiforth (late) Thomas, Esq......

Stainiforth, Samuel, Esq...
Liverpool

Edinburgh

Coventry

Bury-st. St. James's

Rickevich in Iceland

Liverpool

Manchester

Rome

Chelsea

Dublin

Exeter 'Change

Liverpool

Sunderland

Frogmore

Wrexham

22, Gower-street

Curzon-street

Hailesworth, Suffo

Liverpool

Denston Hall, Sibj

Liverpool

Lerwick, Zetland

Sheffield

Liverpool

Chelsea

Edinburgh

Edinburgh

Coventry

Coventry

Norwich

Dublin

Liverpool

Hull

Mead-place, Lambeth

Liverpool

Liverpool 
Stanley, Lord, M. P.

Stanley, Col. M. P

Stanhope, Spencer, Esq. M. P.

Snow, Mr. Surgeon.

Spires, Mr. T

Steel, Mrs.

Stephenson, W. Esq

Strong, W. Esq.

Strang, James, Esq

Stuart, Captain

Symmons,

Taylor, Col

Teignmouth, Lord.

Thorald, Rev. G.

Thorpe, J. Esq.

Townley, John, Esq

Townsend, Rev. J

Trail, Tho. Esq

Trail, Miss

Trigge, Lady....

Tratford, John, Esq.

Turmeau, John, Esq

Turner, William, Esq

Unit, Mr.

Urquhart, John, Esq

Vaillaint, Mons.

Vandes, Le Count De

Vaughan, Sir Robert

Vaughan, Rev. Ker, F.L.S.

Walker, Sir Patrick, F. L. S...

Wallis, Mr.

Ward, R. Esq.

Warre, J. Esq

Webber, W. Esq

Weston, Rev. Mr

Wilkinson, J. Esq.

Wilson, Mr.

Wilson, Mr.

Wilson, Lady

Wilson, Sir Thomas....................

Wright, Di. Peter......................

Wright, R. Esq. F.L.S..............

York, Dean of

Young, Dr. F. L.S
Knowsley

London

Highgate

Leadentıall Market.

Anglesea

Norreich

Isle of Sanda

Fair Isle

Edinburgh

Paddington Housc

Windsor Castle

London

Syston Park, Lincolns.

\section{Torenley}

Bath

$\{$ of Holland, Papa

Westra (Orkney)

Ditto, Ditto

Saville Row

Trafford House

Liverpool

Llangollen

Birmingham

Kirkwall

Paris

London

Dewonshire

Edinburgh

Hull

Sheffield

George-st. Hanov. sq. Melina-place, Lambeth

Bath

Glasgow

College, Edinburgh

Charlton

South End

Glasgorv

Litchfield

sheffield 


\section{A \\ COMPANION}

TO THE

\section{LONDON MUSEUM.}

The Number at the Corner of each Case refers to the Page of this Catalogue, in which it is described.

\section{SANDWICH ISLANDS. Case No. * $^{*}$}

LETTER A.-A superb Cloak, made of the black feam thers of the Powihee bird, ornamented with a broad checquered border of red and yellow. This cloak is so long as to touch the feet of the wearer, and is considered of the greatest value. It is worn by none except the chiefs, and by them only on particular occasions; as they never appeared in them but three times during Captain Cook's stay at Owyhee; viz. at the procession of the king and his people to the ships, on their first arrival; in the tumult when the unfortunate commander fell a victim to their fury and mistaken resentment; and when two of the chiefs brought kis bones to Captain Clarke.

B.-Red-feathered Cloak, decorated with yellow, from ditto. The ground of these elegant and singularly beautiful cloaks is net-work wrought by the hand,

* Several of the articles in this Case were once the property of the celebrated Captain Cook. 
upon which the feathers are so closely fixed, that the surface resembles the thickest and richest velvet, both in delicate softness and glossy appearance.

C.-A Helmet, composed of wicker work, covered with red feathers.

D.-Another Helmet of a different construction, covered with black feathers. These helmets, with the dresses, form the principal riches of the chiefs of the South Sea Islands.

E. - A large Hat, made of red, yellow, and black feathers; remarkable for its resemblance in form to those of Europe.

F.-Two Neck Ornaments, made of different coloured feathers, from the Sandwich Islands.

G.-Breast-plate, or Gorget, from Otaheite, made of wicker, covered with feathers, and ornamented with rows of shark's teeth.

H. - Small Idol, of black wood, from ditto.

I.-War-club, from the Sandwich Islands. This club, which belonged to a chief of Owyhee, is armed with a very hard, sharp, polished stone, which makes it somewhat like a battle-axe; the other end is pointed, for the purpose of a pahoo or dagger.

K.-A Basket, from the Friendly Islands.-That the untutored Indians of the South Seas exceed the artists of every civilized nation in this kind of work, the above basket is a proof; as it is of so close a texture as to hold any liquid. It was used by the gentleman who brought it from the South Seas (and who presented it to this Museum) as a punch-bowl.

L.-Fish-hook, from the north-west coast of America.

M.-A Necklace, made of the teeth of the Peccary.

$\mathbf{N}$ - - Head Ornament, made of mother-of-pearl and tortoiseshell.-New Caledonia.

O. - A beautiful Fly-flap, purchased at the sale of the late Leverian Muscum. In the first part of the Re- 
ference Catalogue to this once celebrated repository of curiosities, an account is given, in a note, of the manner in which it came into the possession of Mr. Samwell, the late surgeon of the ship Discovery, who published a Narrative of the Death of Captain Cook; he informs us he brought this Fly-flap home with him, and of which lie gives the following account: "The natives of the Sandwich Islands always endeavour to carry off the dead bodies of their friends slain in battle, even at the hazard of their own lives. This custom is probably owing to the barbarity with which they treat the body of an enemy, and the trophies they make of his bones; a remarkable instance of which I met with at Atowai. Tomataherei, the queen of that island, one day paid us a visit on board the Discovery, accompanied by her husband, T'aeoh, and one of her daughters by a former husband, whose name was Oteeha. The young princess, who was called Orereemo-horanee, carried in her hand a very elegant Fly-flap, of a curious construction. The upper part of it was variegated with alternate rings of tortoiseshell and luman bone; and the handle, which was polished, consisted of the greater part of the os humeri (bone of the upper arm) of a chief, called Mahowra; he had belonged to the neighbouring island of Oahoo; and, in an hostile descent he made upon this coast, had been killed by Oteeha, who was then ling of Ootwai. His bones were in this manner carried about by Orereemo-horanee, as trophies of her father's victory. The mother and daughter set a great value upon it, and were not willing to part with it for any of our iron; but Tomataherei happening to cast her eye upon a wash-hand-basin of mine, which was of queen's ware, it struck her fancy, and she offered to exchange. 1 accepted of her proposal, and the bones of the unfor. tunate Mahowra came at last into my possession."

P.-An Under Garment, made of the bark of the Touta, or Cloth tree, curiously decorated, from the Saudwich Islands; presented by the Rev. Dr. Clarke.

Q. and R. - Two Caps from Africa; one made of grass, which for fineness of workmanship and regularity 
of pattern exceeds any thing of the kind of Europears manufacture. What must appear wonderful in this work of art is, that it is knit with wooden sticks, after the manner of stockings. The one marked $\mathbf{R}$, was presented by Captain Campbell, and is made of the fibres of bark.

In the other Case of South Sea articles is the upper part of the Chief Mourner's Dress of Ceremony at the Funerals of Otaheite. The part worn over the face is of large plates of mother-of-pearl shell, fastened together with fibres of the cocoa-nut: opposite the right eye is a hole for the purpose of seeing through; the edges of the face-plates are bordered with the long tail-feather of the tropic bird, and make an elegant appearance; across the breast is stretched a most elaborate drapery, composed of several thousand pieces of mother-of pearl, each separately drilled and fastened together in a manner that would be found difficult for an European artist to copy, even with the advantage of iron tools, which were totally unknown to these Islanders.

This very interesting article was, (with many other valuable curiosities) presented to the Museum by Sir Joseph Banks, whose liberality and patronage of every thing connected with the promotion and diffusion of knowledge and science are too well known to be noticed here.

In the same Case are two of the monstrous and uncouth Idols, made by the natives of these islands. The ground is of wicker, worked into a rude and exormous representation of the human head. - They are covered with red feathers, and the mouth (near a foot long) is thickly set with teetls of the seal. The eyes are composed of pieces of mother-of-peal, with a round knob of black wood in the centre, and the head of one them is rendered more terrific by being adorned by a large quantity of the snaky tresses of the natives.

A fine Feather Helmet and Cloak from the Sandwich Islands, presented to the Museum by the Rev. Dr. Clarke; and an extremely curious pair of Bracelets, made of boar's teeth, presented by Mr. G. Humphrey.

On the Rail of the Gallery are hung a number of the 
weapons, \&c. of the South Sea Islanders, among which are,

Tabooing Roas or Wands. One of them is made of a beautiful close-grained red wood, and is pointed: on the other is the head of the Eatooa, or God, finely carved. These wands are carried by the priests, and sometimes by another person particularly appointerl to that office, who is called Tonata, (or the Taboo Man.) They are made use of on various occasions, both pub. lie and private, and any thing touched by them is considered as prohibited or forbidden. The word Taboo, used emphatically to denote any thing sacred, eminent, or devoted. When a particular space of ground is tabooed, several of these rods or wands, tufted with dog's hair, are fixed up, and until they are removed, no person will presume to tread on that ground. Otakeite.

Different kinds of long $W a r^{*}-c l u b s$ used in the Friendly Islands. These are made of wood, equal in hardness to the Brazilian, and superior in beauty to mahogany: and when it is remembered that iron and steel are wholly unknown to these people, few specimens, for laborious and skilful workmanship, can vie with them. The carving, though executed with no other instrument than a shell, a shark's tooth, or a flint, by dint of industry and ingenuity, is perfectly uniform in pattern, and highly ornamental.

Paddle or Oar, with which the natives of the Friendly Islands row their canoes. It is about five feet long, and six inches across the widest part, and yet is so light as to weigh little more than a pound!

Various kinds of short Hand-clubs, or Pattapattoos, of different forms and materials. They are worn by the natives of the South Seas, in the same manner as daggers are worn by the Asiatics, and are usually made of hard wood, bone, green jade stone, or basaltes.

$A$ Knife, from the sandwich Islands, made of wood, edged with shark's teeth, used by the natives of those islands for cutting up their enemies taken in battle. 
Basket, from New Zealand.

Axes, or Adzes, made of very hard black stone of the luasaltes kind. 'The hatchets are wrought in a regular

- form with much labour, by rubbing one stone against another; with these the natives cut the wood for their canoes, war-clubs, and household utensils; the heads of these axes are firmly fastened on to the handles with strong cords, made of the fibres of the cocoa-nut twisted together.

A large Fish-hook, for taking the shark; it is one foot long and six inches broad, and is made of a crooked piece of wood, pointed at the end with a substance resembling horn. Otaheite.

Near these are several of the military and domestic implements of New Holland, presented by Dr. Jamieson.

SMALI GLASS CASE, MARKED A.

A pair of ponderous Ear-rings, nade of white shells, from Christian's Island.

A Necklace of human bone, from New Zealand.

Beautiful Feather Necklaces, from the Sandwich Isles.

Gaiters, worn by the dancers of the Sandwich Isles. The ground-work is a strong close netting, on which are fastened several hundred small shells, which, when put in motion, produce a rattling sound, to the music of which the dancers keep time.

In this Case is also a variety of the Fishing-tackle of the Sandwich and Friendly Islands. The hooks are made of mother-of-pearl, bone, or wood, pointed or barbed with small bones or tortoise-shell. They are of various sizes and forms; that marked $\mathrm{A}$ is the most common: it is between two and three inches long, and made in the shape of a fish, which serves as a bait. B is of a tortoise-shell.

The lines are made of different degrees of strength and fineness. That marked $\mathbf{C}$ is the finest kind, and is of buman hair plaited together, and is used chiefly for things 
of ornament. D is a specimen of the common kind, made of the bark of the cloth-tree, neatly and evenly twisted in the same manner as our common twine. $\mathbb{E}$ is a softer kind, made of the bark of a small shrub called Areemah, plaited together, and is flat. That marked $F$ is of great strength, being made of the plaited sinews of some sea anima!.

They likewise make another sort of cordage, which is flat and very strong, and used principally in lashing the roofs of their houses, or whatever they wish to fasten together; it is made of the fibrous strings of the cocoa-nut husk, in the same manner as our sailors make their points for the reefing of sails. That on the shark-hook is of this kind. Considering the materials of which these hooks and lines are formed, their strength and neatness are really astonishing: "and in fact," says Captain Cook, "we found them upon trial far superior to our own."

The Combs marked $G$ are from the Friendly Islands; and are specimens of their exquisite wicker-work.

A quantity of Fishing-lines, made from human hair, brought from the South Seas.

A Net-mesh, from the South Seas.

A Shoe of a Chinese lady.

A Shoe of Count Borulaski, the Polish dwarf.

A Tattowing Instrument, from Otaheite. Captain King, in his Continuation of Captain Cook's Third Voyage, vol. iii. p. 135, observes, "That the Sandwich Islanders have the custom of tattowing the body in common with the rest of the natives of the South Sea lslands. The arms and hands of the women are also very neatly marked, and they have a singular custom among them, the meaning of which, "Captain King says, "we could never learn, that of tattowing the tips of the tongues of the females. From some information we received relative to the custom of tattowing, we were inclined to think it was frequently intended as a sign of mourning on the death of a chief, or any other calamitous event; for we 
were often told, that such a particular mark was in memory of such a chief, and so of the rest. It may be here, too, observed, that the lowest class of natives are often tattowed with a mark that distingnishes them as the property of some chief."

Model of a Canoe.-Nootka Sound.

New Zealand Canoe,

Models of Canoes of different nations, Eskimaux, Davis's Straights, New Zealand, \&c.

Lines for Fishing, made of human hair.

Basket to hold liquids, from the Sandwich Islands, South Seas.

Bread Pounder, from Otaheite. It is made of black basaltes, and is an astonishing effort of labour, executed by a people to whom the use of iron instruments are unknown. It is used in pounding the bread-fruit.

Spear-caster, from New Caledonia, by means of which the natives strike fish with a surprising celerity.

Caps, from Nootka, or King George's Sound, made of sea-grass finely woven together; on one is designed the process of their whale fishery. "This," says Captain Cook, "though rudely executed, serves to show, that though there is no appearance of the knowledge of letters among them, they have some notion of representing actions in a lasting way, independent of what may be recorded in their songs and traditions." They are worn by both sexes without distinction.

Hats, from South America, made of the feathers of parrots and other birds.

Mratting, from the South Sea Islands.

A Mantle, from New Zealand. This kind of ornament passes under the right arm, and ties over the left shoulder, by which means both arms are at liberty. It is made of flax so curiously knotted together, that on examination it 
must astonish the beholder; more especially when he con siders that it was made by a nation to whom the loom is unknown.

Wooden Sword, from Botany Bay. It is worthy of remark, that when Captain Cook first discovered New Holland, he was surprised to behold the natives so expert in handling the sword after the European manner, from which he concluded they had seen and copied the use of that weapon.

Bows and Arrows of different nations.

Two small Clocks, made of feathers, to cover the shoulders, from the South Seas.

GLASS CASE OF BOTANICAL SUBJECTS.

Most of the articles in this case were presented to the Museum by Dr. Janies E. Smith, President of the Linnrean Society.

Specimens of the Bark of the Lagetto Tree, the curious structure of which resembles gauze. King Charles II. it is said, had a pair of ruffles and a cravat made from this bark, which were presented to him by a merchant from Jamaica, which he frequently wore. The cloth of the South Sea Islands is made from a similar bark.

Fine specimen of the Banksia Serrata, in flower. This is one of the four species of Banksia described in the Supplementum Plantarum of Linnaus, specimens of which are contained in the Herbarium of that great naturalist, now in the possession of Dr. J. E. Smith.

The Banksia Serrot $a$ is considered as the most stately of the genus: its trunls is thick and ruggid. It is a native of New Holland, and received the denomination of $B$ ands. sia in complement to Sir Joseph Banks.

Banksia Serrata in Fruit, a fine specimen.-New Holland.

Wooden Pear (Xylomelum Pyriforme). This species was first discovered at Botany Bay, when the coast of 
New South Wales was first explored by Sir Joseph Banks and Dr. Solander. The natives call it the Merrydugur-ro. The tree which bears this ligneous pear is an evergreen.

Heath-leaved Bantesir (Banksia Erici-folia), from New Holland.

Yellow Gum (Xanthorrhoa Hastile) from Botany Bay.

Cylista Comosa, from Sierra Leone.

Afzelia Speciosa, from Sierra Leone.

New Zealand Flax, (Phormium Tenax) of which the natives make their cloaks, twine, \&c.

Strings of Beads, made of aromatic berries, from South America.

Cotton in the pod and in flower.

\section{CURIOSITIES}

FROM NORTH AND SOUTH AMERICA.

A Dress worn by the Eskimaux Indians, principally made of seal-skins, with the hairy side outwards. It is a kind of jacket, nearly resembling a carter's frock, with a hood to it, that fits tight round the face, which is the only part of the body that is seen; the skirts of the frock reach nearly to the knee, and under it are worn a kind of drawers, made of the same materials as the above: the legs are covered with stockings made of skin, with very thick hair on, and over these are drawn a pair of curious boots, made of the skin of some sea animal. The whole of this dress is well calculated for the cold clinate where it is worn. The sewing is performed with small sharp tish bones, and the sinews of the whale split into thin fibres for thread; yet we believe that few European tailors could exceed either the neatness or strength of the work. 
Halter, made of the bark of the Lagetto or Cabbage tree.

Mancassons, or Shoes, worn by the Indians of Nortin America, ornamented with porcupine quills and tassels of red hair. The leather is said to be dressed in blood, which prevents the wearer's feet from freezing; on which account they are often used by Europeans in that country.

A Quiver of poisoned Arrows, with the Tube used in discharging them; brought from Demerara. These instruments of destruction are nine inches long, and about the thickness of a small quill; they are made of a light wood, sharply pointed, and are dipped in poison to the depth of two inches, which generally proves fatal to the object that is wounded by them: they are discharged with unerring certainty, by being blown through a hollow tube of wood, nine feet long. Near the quiver hangs a small basket, which contains a down-like substance, a small piece of which is put into the tube after the arrow, which prevents the escape of the air, and causes it to fly with almost incredible velocity.

An ornamental Belt, used by the North American Indians, for bringing home the skins of animals taken in hunting excursions.

Bow und Fish Arrows, from the north-west coast of America.

Several Pouches, some of them very curious, from North America.

Pair of ornamental Garters, principally made of porcupine quills, from North America.

A Purse, or Tobacco Pouch, made of the skin of the stiffling or squash, ornamented with tassels of deer's hair, from North America.

Ornament for the neck, made of the shells of some small hard nut, from Demerara.

Bow and Quiver of Arrows, from Demerara. 
Several Musical Instruments, from Demerara, among which is a kind of finte.

A great variety of Bows and Arrows from Surinam.

Calumel, or Pipe of Peace, used by the North American Indians, to smoke tobacco, bark leaf, or herb, when they enter into an aliiance on any serious occasion, or solemn engagement; this being among them the most sacred oath that can be taken, and the violation of it is thought deserving of the punishment of heaven.

A Snow Shoe, from Hudson's Bay, upwards of five feet long; it is very light, and covers such a space as prevents the feet of the wearer from sinising into the snow.

A pair of Snow Shoes, for a child.

A pair of Snow Shoes, from Canada, not so long as the preceding, but broader and rounder in front.

Neck Ornament, made of feathers, from South America.

Two Hammocks, of curious workmanship, from South America; presented to the Museum by the Hon. Col. St. Leger, of Dublin.

\section{SMALL GLASS CASE, MARKED C.}

A Wampum Belt, of great value among the Indian chiefs of North America, often given and received as a token of peace.

A Cap, from Africa, made of plaited grass.

Chinese Money. These pieces have square holes through them, and are always strung together. Seventysix of them are the value of an English sixpence.

Rouge, used by the Chinese ladies to colour their faces.

Specimen of the Cloth made of amianthus, a soft species of asbestos, that will remain in the hottest fire without burning. Pliny mentions his having seen napkins of this cloth, which being taken from the table after a feast, 
were thrown into the fire, and by that means were better cleansed than if they had been washed in water. But its principal use, according to that author, was for making shrouds for royal funerals, to wrap up the corpse, so that the human ashes might be preserved distinct from those of the wood.

Asbestos, or Mineral Flax, in its natural state.

Mica, or Talc, used for windows before the invention of glass. Clear white plates of this substance are used for glazing the lanterns of men of war, as fire has little effect on it.

\section{AFRICAN CURIOSITIES.}

African King's Sceptre, in shape like a rod, being made of small split pieces of bamboo cane. These are valued according to their length, for by that the rank of the person is known; that of the king's being made of the longest joints of bamboo that can be found in his dominions.

Curious Sword, formerly the property of a Mandingo chief. Inclosed in the hilt is a fettish or charm, to preserve the wearer's life, composed of a piece of skin of the Iguana, which in that country is held sacred.

Curious Cartouch-boxes.

A circular Fan, covered with a parchment-like skin, curiously painted.

Several Pouches, some of them very singular in construction.

A pair of Sandals, or Shoes. These, in Africa, are seldom used.

Common Black Bottle, curiously cased with wicker. work.

African Comb, similar to that of the Sandwich Islands, 
A rude Necklace, composed of stones that have holes maturally through them, without boring.

African Spoon, made of wood.

Curious Wooden Fan.

A lady's large Pocket, or Pouch, finely embroidered with the needlework of the country.

African Bows and Quivers of long poisoned Arrows.

Great variety of African Lances, Arrows, and Daggers.

A small instrument, similar to a Scottish Mull, used for the purpose of grinding tobacco into powder.

An African Flambeau, made of flag-leaves, filled with a resinous gum.

Pouch, or Pocket, made of grass, used by negro servants to carry letters, \& c.

A kind of Hammock, of singular net-work, used in A frica, either for sleeping or travelling.

Small Gourds, covered with net-work, on the meshknots of which are strung a kind of Black-Berries, that produce a sound similar to castinets. They are used by the Africans when they dance.

An African Charm, called Fettish, consisting of a Ram's-Horn, to which is suspended a brass chain and bell. This is worn round the neck, and is imagined by the wearer to charm or drive away evil and tormenting spirits, and preserve life. It was taken from the breast of a black man engaged in battle, by Captain Clarke, of the ship Roebuck, of Liverpool, who presented it to the Museum.

Specimen of African Cloth, made of grass.

A curious Sleeping Net or Hammock, from Africa, presented by Captain Roberts, of Liverpool. 


\section{WORKS OF ART.}

Beautiful Equestrian Model of Edward the Black prince in Armour, finely executed by Mr. G. Bullock of Liverpool.

Portrait of Mrs. Siddons, in Queen Catherine, and $M r$. Kemble, in Coriolanus, by ditto.

Capital Group of Figures, representing the Progress of Inebriety.

A Blind Beggar led by a Child.

Frederick the Great in his last illness.

And, a Dead Christ.

[The last four pieces are all modelled by Mr. Piercy, in coloured wax, and are universally admired by every lover. of the arts, for the correct and spirited manner in which they are executed.]

An exquisite Model, in Rice Paste, of the Death of Voltaire, by Mons. Oudon, of Paris.

Gothic Model of an Ancient Armoury, on the scale of an inch to a foot. It contains accurate models and representations of every kind of Armour and Warlike Weapon used in the British armies, from the Norman Conquest to the Restoration of Charles II.

Group of Flowers, wonderfully cut in white Marble.

Model of a Chinese Pagoda, made of mother-of-pearl, ornamented with carving and gilding.

Complete Model of a Man of War, only six inches long.

A ditto, entirely of ivory.

Windsor Castle, with the Thames.

Greenwich Hospital, with Shipping, \&c.

Two pieces with Stags in a Forest.

[The above four are all in Ivory, carved in the most exquisite manner by Messrs. Stephany and Dresh.] 
Sixteen hollow Balls of Ivory, cut within each other out of one solid piece, by the Chinese, in the most wonderful manner, every ball being pierced of a different pattern, almost as fine as lace.

Another ditto, with only eight Balls.

Several beautiful turnings in Ivory, by Mr. Perry, of London.

Picture of a Saint sailing on his Cloak, in Marble of its natural colours.

Case of Flowers, made of Butterfly's Wings. Riome.

Holy Family, from Carlo Maratti, done in Wood, at

Picture of Birds, exeruted with Feathers. Straw.

A Dutch Merry-making, from Teniers, in coloured

A Jew Rabbi, done with a hot iron on Wood.

Several Copies of Engravings, with Pen and Ink, by Mons. Mongenot.

Model of a Man of War, of sixty guns, entirely of Crystal Glass; an early work of the Proprietor.

Complete iModel of a seventy-four gun Ship at anchor, only six inches long.

IN A CASE NEAR THE EN'TRANCE, ARE,

A curious ancient Dish, inlaid with mother-of-pearl and various coloured glass, \&c. Ancient Work Basket, made of cane and different coloured silk. Large Hat, made of cane, curiously wrought, of the time of Elizabeth.

Pair of ancient Stockings, of crimson silk and gold; they are very strong, and curiously ornamented on the 1op: supposed to be of about the time of James I. 


\section{SHOES.}

\section{OF DIFFERENT NATIONS.}

Roman Sandal. The strings which lace it in front, the sides and bottom, most ingeniously made out of one piece of leather; it was found at the depth of fourteen feet, in cutting peat in Hawford Moss, Cheshire.

Turkish Slipper, of yellow leather.

Persian Shoe, red leather, embroidered with silver.

East India Shoes, of curious form, and highly ornamented.

A Pair of Bramin's Shoes, from the East Indies. Perhaps no article of dress, to the eyes of Europeans, will appear more extraordinary than these shoes:- they are made of hard wood of one piece, in the form of the sole of the common shoe, raised from the ground about the height of a patten, by a projecting piece of wood being left at the toe and at the heel. They are fastened to the feet by a pey of wood that stands between the two largest toes, which secures them in walking.

Chinese Men's Shoes; one of them of cane, beautifully wrought; the other of satin, embroidered; the sole of woollen cloth, near two inches thick, and bent up before in such a manner as to keep the toes constantly raised.

Pair of shoes worn by ladies in China, whose feet have been cramped by the use of the iron shoe, and a Model of the Leg and Foot. These are of a size so extremely diminutive, that on the first view it appears impossible they could have been worn by a full-grown person; they are rather more than four inches long, and are not an inch wide in the middle. This ridiculous custom is said to be performed by breaking the bones of the feet of the females while infants, bending the toes under the soles of the feet, applying a tight bandage, and over that an iron shoe, which prevents the feet from enlarging, and render these unfortunate victims of fashion cripples for life. 


\section{NATURAL HISTORY.}

\section{Birds. (Class Avis)}

\section{Almighty Being!}

Cause and support of all things, can I view These objects of my wonder; can I feel These fine sensations, and not think of thee?

Th1s Ornithological department of the Museum contains probably a greater number of species than is to be found in any other collection: they are in the highest possible state of preservation, and arranged in their respective families, according to the Linnæean Classification, in a manner that has met the approbation of the scientific naturalist as well as the general visitor; as combining the whole of the Birds of one genus together, and exhibiting them in the order they stand in the Systema Natura, in such a way as convey an idea of their haunts and mode of life.

The landscapes at the back of each case are intended to show the description of country in which the respective birds are generally found.

\section{BIRDS OF PREY. (ORder ACCIPITREs.)}

\section{VULTURE (VULTUR.)}

The vultures are the most ravenous of the feathered tribe, since they kill prey not from choice but in general 
devour only such animals as are dying, or found dead and putrid. Their sense of smelling is so exquisite, that they are able to scent a dead carcass at an amazing distance. "They are," says Pennant, "greedy and vora"cious to a proverb, and not timid, for they prey in the " midst of cities, undaunted by mankind." In some of the battles of the East, where vast slaughter takes place of elephants, horses, and men, voracious animals crowd to the field from all quarters, of which Jackalls and Vultures are the chief. Even in the places where the last are at other times seldom observed, the plain on these occasions will be found covered with them. Vast multitudes will be seen in the air, descending on every side to partake in the carnage. These the Indians believe to be brought by having an instinctive presentiment of slaughter some days before the event. It is observed, that Vuitures in general become less numerous as the climate becomes colder; and that in the more northerm countries they are never found.-They are undoubtedly a kind dispensation of Providence in the hotter regions, to prevent the putrid effluvia of the dead from too much injuring the health of the living.

Bearded Vulture. (Vultur Barbatu.) This fine specimen was presented to Mr. Bullock by the Museum of Natural History of Paris. This species is distinguished by the tuft of hair which grows beneath the under mandible.

In the same case are two specimens of a smaller species of Vulture; of which no description appears hitherto to have been given.

Fulvous Vulture. (Vultur Fulvus.) This large species inhabits the mountains of Persia, and is occasionally seen in the warmer parts of Europe, but is no where plentiful.

Crested Vulture. (V. Cristatus), from the Cape of Good Hope.

Carrion Vulture. (V. Aura.) These inhabit the greater part of America, where they are protected for their use in devouring dead carcasses, serpents, \&c. In towns they will seize meat from the shambles. 
Their manners are filthy in the extreme, and their breath emits a most unpleasant odour.

Is the female of the King Vulture. (See Case below.)

The King of the Vultures. (Vultur Papa.) This is the most beautiful of the whole tribe; it is an inhabitant of South America, and is protected on account of its services in destroying dead and noxious animals.

2. Is a young bird of the first year; it is not till the third that they attain their mature plumage.

Secretary Vulture, or Serpent Eater. (Falco Serpentarius, Linn.) This remarkable bird is found in the country in the interior of the Cape of Good Hope. Its principal food is serpents, which it is extremely expert in destroying. One that was kept alive some years since at Exeter Change was fed on live eels, which it killed by striking them severely near the head with its foot. Presented to the Museum by the Dean and Chapter of Christ Church College, Oxford.

\section{BRITISH EAGLES. (FALCO.)}

Male of the Sea Eagle. (Falco Ossifragus.) This extremely fine specimen, which measures 7 feet 9 inches in the extent of its wings, was killed in Lincolnshire in March, 1810, in the park of Sir Joseph Banks, by whom it was presented to the Museum.

Female of the Sea Eagle, (which in the rapacious birds are larger than the males) it was shot in the winter of 181(), in the New Forest, whilst in the act of tearing out the eyes of a deer on whose head it had fastened. Presented by Michael Hoy, Esq.

Black Eagle. (F. Melanaetos.)

The Osprey, or Fishing Eagle, Male and Female. (F. Halioetos.)

Golden Eagles. (Falco Chrysøotos.) A matchless group of these noble birds, consisting of the male and 
female, and young, beautifully preserved. The male is represented as just arrived at the nest, with a white hare, the lungs of which it is tearing out for the unfledged Eaglet, who stands ready to receive it. We procured the young from the awful clifts near the romantic village of Rackwick, in the Isle of Hoy. The nest (if a bare rock with a little grass strewed on it could be so called) was on a small ledge of the rock, the upper part of which projected in such a manner that rendered it impossible for man to approach it. After several unavailing attempts,-we killed one of the young (there were two in the nest) with the gun, the other, on being fired at the following day, struggled over the ledge of the clift, and was killed by falling several hundred feet on the rocks beneath. The parent birds were in sight, but did not attempt to defend their young.

The female was killed in the winter of 1809 , in the neighbourhood of London, and presented to the Museum by the Count de Vandes.

A pair of these birds breed annually in the bold rocks in Hoy, called the White Breast, the ground above the place, for a considerable distance round, is strewed with the numerous remains of sheep, lambs, pigs, poultry, rabbits, and fish, and exhibit a striking example of the havoc and destruction caused by the numerous birds of prey in that island.

Ring-triled Eagles, male and female. (Falco Fulvus.) These are described by naturalists as distinct from the Golden Eagles; but we have no doubt of their being really the same in the most perfect adult state. They were killed in the Isle of Hoy, where they breed. This species is trained by the Tartars to hunt hares, antelopes, and foxes.

Cincerous Eagle, (Falco Albicilla) with its young. This is somewhat less than the Golden Eagle, the colour is also much lighter, and the bill straighter and larger than in any of the other species; it inhabits the northern parts of Europe and America. The young ones were taken on the 10th of June, 1812, when about three weelss old, from their aeiry on the tremendous clifi called the 
West Craigs, in the Isle of Hoy, (one of the Orkneys) the towering rocks of which rise to the perpendicular height of 1200 feet from the sea. About one-1hird of the way down this awful abyss a slender pointed rock projected from the cliff, like the pinnacle of a gothic building; on the extremity of this is a hollow, scarcely of sufficient size for the purpose these birds had fixed on as a place of security for rearing their young; the situation was such as almost to defy the power of man to molest their habitation; yet with the assistance of a short slender rope, made of twisted hogis bristles, did the well-known adventurous climber, or Rocksman, "Woolley Tomson," traverse the face of this frightful precipice, and for a trifing remuneration brought up the young birds.

After a fatiguing scramble up the sides of the mountains, we arrived at the place from whence we could see the aeiry beneath, the distance was so great that the young Eagles appeared no larger than pigeons; after placing us in a secure situation on a projecting ledge of the ruck, that commanded a view of the scene of action, Tomson left us, carrying his rope in his hand, and disappeared for upwards of half an hour; when, to our great joy, we discovered him creeping on his hands and inees up the spiry fragment, on which lay the unfledged Eaglets; when knowing he was then in our sight, he knelt on the top, and looking towards us, waved his hat. At this time it was impossible to see the situation he was in without trembling for his safety; the slender point of the rock on which he knelt was at least 800 feet above the surges of the Atlantic, which with unbroken violence were foaming beneath him. Yet he deliberately took from his pocket a cord, and tying the wings of the young birds, who made some resistance with their bills and talons, he put them into a basket, and began to descend, and in a few minutes the overhanging masses hid him from our view. The old birds were in sight during the transaction, and made no attempt to defend their young: but soaring about a quarter of a mile above, occasionally uttered a short shrill scream, very different from their usual barking noise. Had they attempted a rescue, the situation of the climber would have been 
extremely dangerous, as the slightest deviation or false step would have precipitated him into eternity, a misfortune that a few years since befel his brother, on the same spot, when in his company.

After waiting in a most painful state of suspense for near an liour, our climber suddenly made his appearance, and, laughing, presented his prize.

In the Isie of Hoy we discovered all the species of British Eagles, except the Osprey: they are extremely numerous, and are the greatest pest of the poor inhabitants, frequently carrying off their lambs, pigs, and poultry. Near the nest of one we found the remains of several lambs, and the legs of 48 fowls were found near another. It is but a few years since a person, died, who in his infancy had been carried off by an Eagle, and recovered by his parents. By an ancient law in the Orkneys, any person destroying an Eagle is entitled to $a$ hen from every farm in the parish in which it occurred.

\section{BRITISH HAWKS. (FALCO.)}

THIs Case contains most of the Hawks found in Britain, with their names attached to them. They are all birds of prey, many of them may with care be brought to a state of partial domestication, and were formerly used in the noble diversion of hawking; among them are,

Rough-legged Falcons. (F. Lagopus.) Three specimens of these British birds, which seldom visit the British Isle, being natives of the north of Europe and America.

Goshawk. (F. Palumbarius.) This bird, which is now becoming scarce in England, is admired for the beauty of its plumage: it was formerly used in falconry.

Merlin. (F. Esalon.) This is one of the birds that migrate to the southern countries on the approach of winter. 


\section{FOREIGN EAGLES. (FALCO.)}

IN this case is a variety of birds of the Falco genus; several of them are very rare, from South America: those known have their names attached to them. Among the most conspicuous is a fine specimen of the Bald, or White-headed Eagle. (Falco Leucocephalus). It is found in great plenty on the shores of Hudson's Bay; and I am informed by my brother (Lieut. BuLlOCK, R. N.) who passed several winters at a Block-house on the coast of Labradore, that these birds were so bold as to be extremely troublesome, by watching for and seizing the game killed by the guns of our people, and often contending with them for the prize.

The Imperial or Crested Eagle. (Falco Imperialis.) This majestic bird is a native of the woods in the interior of Cayenne and Guiana, where it preys on the various species of Monkeys and Ant-Eaters; it is said also frequently to destroy the large Serpents of that country, in which act it is preserved, combating an undescribed poisonous species, whose deadly fangs are erected as in the moment of inflicting its fatal bite. The Imperial Eagle is perhaps the most powerful of this rapacious family, the size of its legs and talons (the hind ones in particular) sufficiently mark its strength. It is represented here in the act of destroying a formidable serpent: and is the only specimen of this bird known to have been brought to Europe.

Sonnini's Eagle. This is is one of the most beautiful of the Falco genus. Its form is more slender and elevated than its co-geners: its colour, dark chocolate feathers down to the toes, and the feathers of the head lengthened into a crest. It is a native of Brazil.

Superb Eagle. An elegant bird, found near the Cape of Good Hope.
Pondicherry Eagle. Holland.
(F.) Found in India and New

Zone-tailed Eagles. Male and female. 


\section{AFRICAN HAWKS.}

A collection of Hawks from Africa, consisting of twelve species, several of which are undescribed.

\section{BRITISH OWLS. (STRIX.)}

EVERY species of Owl hitherto recorded as found in Britain is contained in these Cases, to the list of which we now add one of the most beautiful and majestic of the genus, the Great Snowy Owl (Strix Nyctea). In July, 1812, in the Island of North Ronaldsliaw, one of the Orkneys, we were informed that a bird of this kind had been seen on the rabbit warren on Links for several weeks, and shortly after I had an opportunity of examining it for some time, at the distance of about forly yards. It was a male, (the spicinen now in the Museum) and its companion had been killed a few months before on the Island; one of them had likewise visited the adjacent Isle Westra, and remained there for some time. In Sep. tember I was so fortunate as to procure one in Unst, the most northerly of the Shetland Isles. It had been killed a few weeks before by Mr. L. Edmonston, a young gentleman well versed in the Ornithology of that country, and from whose testimony, as well as that of several gentlemen of the Isle, I have not the smallest doubt of its breeding and remaining the whole year in the mountainous precipices of both that Island and Yell. They are seen there at the end of the summer, in company with their young, three or four together; the latter are then brown. Their flight, which I had several opportunities of observing, was more light and buoyant than any of the Hawks, but not so much so as our common Barn Owl. They prey by day on various animals. One wounded on the Isle of Balta, disgorged a young rabbit whole, and that now in my possession had in its stomach a Sand-piper, with the plumage entire. The Case contains nime species of British Owls. 
Long-eared Owl. (Strix Otus.) This bird owes its British name to the black and yellow feathers which stand upright on its head.

\section{FOREIGN OWLS.}

The Sooty Owl, or Cinerous Owl. (S. Cineria.) One of the peculiarities of the Owl genus, is the disproportionate largeness of the eyes: this species however is an exception to that circumstance, for in this, although one of the largest of the family ( 30 inches long), the eyes do not exceed those of the most minute. This does not appear to have been noticed by any author, probably from their not having examined them while living. It is a native of Hudson's Bay, and is said to prey in the day on hares, grouse, \&c. Presented by Mrs. Lean, of Fenchurch-street.

The Great Snowy Owl of Hudson's Bay. (Strix Nyctea.) This beautiful and majestic species is now added to the list of British birds; we described it in the yth Vol. Part I. p. 175, of the Linnean Transactions.

A pair of Canada Owls. (S. Canadensis.) From North America.

A Brown Owl, from New Holland.

A small Brown Owl, brought from New Zealand by Captain Cook.

The Young of the Wood-Owls, in their curious downy covering, before the appearance of the first feathers.

A variety of other Owls, some of which are undescribed.

\section{BUTCHER BIRDS. (LANIUS.)}

TKESE are the last genus of the rapacions tribe; they are bold and quarrelsome, mostly preying on small birds, which they tear in pieces, sticking the fragments on thorns. Some of them are natives of this country. 
Great Ash-coloured Shrike, or Butcher Bird. (Lanius Excubitor.) It receives its name from its ferocious and cruel habit of seizing small birds by the throat, strangling them, and afterwards fixing them on a sharp thorn and tearing them to pieces.

Barbary Shrike. (Lanius Barbatus.) Remarkable for the splendour of its plumage, in which it differs from its co-geners.

Wood Chat. (L. Rutilus), A very rare British bird.

\section{BUDDS THAT INHABT LONTY TRESS.}

\section{(Order Picre)}

\section{PARROTS. (PSITTACUS.)}

THESE Cases contain a numerous and elegant display of the Parrot tribe, consisting of about one hundred species of Maccaws, Cockatoos, Lonies, Parrots, and Paroquets, of the most splendid and beautiful plumage, nroperly arranged and named.

Of all the foreign birds, the Parrot is best known in this country, and is most admired, not without reason, as it unites the greatest beauty with the greatest docility. Its voice more exactly resembles the human than that of any other bird, and is capable of numerous modulations, which even the tones of man cannot reach. The facility with which this bird is taught to speak, and the degree of memory which it possesses, are not a little surprising. So numerous are the stories respecting the loquacious faculty of the Parrot, that they would fill a volume. Parrots are uncommonly numerous in the tropical climates: the foresis swarm with them, and the beauty of their plumage, though not their natural voice, adds a degree of viracity to the loveliest of scenes. Thongh the Parrot is commonly domesticated in Europe, it will not breed here on account of the cold. It indeed can survive our cold vinter, but its spirits and appetite are both visibly af- 
fected by severe weather. It then becomes torpid and inactive, and seems quite changed from that bustling bird which it appears beneath a more genial sky. Nevertheless, with proper attention, it will live a number of years under the protection of man. The extreme sagacity and docility of this bird, forms the only apology that can be made for the time which is spent in teaching it to talk. At first it obstinately resists all instruction, but seems to be won by perseverance; nakes a few attempts to imitate the first sounds, and when it has once acquired the articulation of one word distinctly, the rest of the lesson is generally learned with great ease. The sagacity and docility, however, which Parrots show in a domestic state, seem also natural to them in their residence among the woods. They live together in flocks, and mutually assist each other against their enemies, either by their courage or their notes of warning. They breed in the hollows of trees, where they make their nests. The larger kind lay only two or three eggg: but it is probable that the smaller ones lay more. The natives are very assiduous in finding out the places where they nestle, for the purpose of procuring the young; because those prove the most tractable and lively which are reared in confinement. Indeed the Indians are not anxious to possess these birds for their talking alone, for sale, or for their beauty, but also for fond; since, though some are ill-tasted, others are very delicate eating, particularly the paroquet kind. Numerous as the species are, and widely as they are disseminated over Asia, Africa, and America, yet it appears that they were not very generally known to the Greeks. The Green Paroquet with a red neck was the first of this family imported into Europe; for Onesicrites, the conductor or admiral of the fleet of Alexander the Great, brought them from the island of Taprobane, the modern Ceylon. They were indeed so new and uncommon, that A ristotle, in his eighth book of animals, seems not to have seen them, and mentions them only from report; for he xays, "there is an Indian bird, called the Psittace, which is said to speak." The beauty of these birds made them however objects of luxury among the Romans, who lodged them in cages of silver, shells, or ivory; and 
the price of a parrot often exceeded that of a slave. To enumerate what number of distinct species of these birds have already been discovered, would be impossible, since our vessels from New Holland and the southern islands are daily adding new ones to this extensive and beautiful genus.

The one in the larger case, marked unique, is the property of A. Harrison, Esq. of Parliament-street, Westminster, to whose liberality we are indebted for many of the rare productions of New Holland: it was received from Port Jackson, where it was shot by Colonel Johnson, and the only one known to have been killed at the colony. The Papuan Lory is considered by some persons to be the most beautiful bird in nature.

\section{TOUCANS (RAMPHASTOS.)}

This Case contains twelve of these highly curious Birds, several of them are undescribed; among the rest are the following :

White-throated Toucan. (Ramphastos Toco). Male and female. The bill of this curious bird is of a most uncommon size, being nearly as large as the whole body, which gives the bird somewhat the appearance of having thrust its head into the claw of a large lobster; this extraordinary bill is seven inches and a half long, and seven in circumference; it is extremely slight, and as thin as parchment. This bird, so formidable in appearance, is quite harmless and gentle; it feeds principally on pepper, which it devours very greedily, gorging itself in such a manner, that it voids it crude and unconcocted; this, however, is no objection to the natives using it again. They even prefer it to that which is fresh gathered from the tree; and seem persuaded that the strength and heat of the pepper is qualified by the bird, and that all its noxious qualities are thus exhausted. It is a native of South America. 
The Piperine Toucon. (Ramphastos Piperivorus.) Male and female.

Aracari Toucan. (Ramphastos Aracari). Is a native of South America, remarkable for the great size of its bill, as well as the beauty of colour.

Yellow-breasted Toucan. (Ramphastos Tucanus). In. habits South America: habits, similar to the last.

In the same Case is the Brazilian Motmot. (Momotus Brasiliensis). This beautiful and remarkable bird is about eighteen inches long, though the body is not larger than that of a thrush: it inhabits unfrequented forests, building its nest on the ground, or in holes abandoned by the Armadillo, and lays two eggs; feeds on insects, which it macerates in water.

Near the last is a variety of it from Mexico, with the crown of the head roufous, and the feather of the tail not bare as in the other.

Above these is the Channel Bill of New Holland, (Scythrops Psittacus). The only one of that genus known.

\section{HORNBILL.}

THE African Hornbill. (Buceros Africanus). Of all the various forms which are met with in the heads of animals, those of the Hornbill appear the most extraordinary; to the enormous bill of the Toucans, nature has added a still larger projection from the forehead along the upper mandible, the precise use of which has baffled the research of the most attentive naturalist. Sixteen different species of these birds are enumerated by travellers and writers, the heads of many of which are preserved in this collection.

Pied Hornbill. (Buceros Malabaricus).

Black-billed Hornbills. (B. Nasutus). Male and female. They are natives of Senegal, and feed on fruits.

Red-billed Hornbill. Dr. Latham, in his Synopsis, makes these only varieties of the former. Linnæus thought 
them male and female, and. Bufton thought they difierer only from age; but by comparing them, the beak will be found to differ exceedingly in shape, so much so, as to leave no doubt of their being distinct species.

In a separate case are thee heads of Hornbills, of very large dimensions.

\section{Crows (Corvus.)}

This Case contains a great variety of the birds of this genus, some of which are highly beautiful in their plumage, while others surprise by their singularity. The various kinds are found by navigators inhabiting every part of the known world. They are in general clamorous and mischievous, easily tamed, and several imitate the human voice distinclly. They are promiscuous feeders: carrion is a favourite food, but they do not object to cater. for themselves by killing rabbits, young ducks, chickens, or any small animals they have strength to overpower. This genus includes the ravens and jays. The Peruvian jay is very handsome.

Ten species, all natives of this lsland, are contained in this Case.

\section{POLLER (CORACIAS。)}

THESE are, in their manner and general habifs, much at lied to the last; many of them are of the most vivit plumage, of which the Senegal Roller will serve as an ex. ample.

\section{ORIOLES (ORIOLUS.)}

\section{AND}

\section{GRACRLES (GRACULA.)}

THis Case contains about 40 Orioles and 8 Grackles.

The Orioles are chiefly natives of America, where by their prodigious numbers, and their voracity, they do great 
injury to the plantations of corn; many of the species build pendulous nests, some of which are suspended at the extreme ends of the branches of trees, with the entrance either at the bottom or side.

They are birds of considerable beauty, the general prevailing colour being black, contrasted with bright red and yellow.

The Grackles are mostly natives of India, where they are frequently kept in cages: some of them imitate the human voice much nearer than any of the parrot kind, for which reason they are frequently brought to this country. They principally feed on vegetables.

\section{BIRDS OF PARADISE (PaRAdisea.)}

THus Case contains, it is presumed, the finest collection of the birds of this kind in Europe, either in respect of number, variety, or preservation.

Greater Bird of Paradise. (Paradisea Apoda). No birds have perhaps more puzzled the naturalist than those which are termed Birds of Paradise. They have been described as the inhabitants of the air, never resting on the earth, and living on the dews of heaven. Others have asserted, that they live on insects; while some have insisted, that they have no legs; others again contend, that they have not only strong and large legs, but that they are birds of prey. But the fact is, that the inhabitants of the Molucca Islands, perceiving the inclinations the Europeans have to obtain these birds, and at the same time taking advantage of their credulity, originally practised many deceits in order to enhance their value. Error however is not of very long duration, and, in the present instance, it was at length discovered that these birds had not only legs, but that they were so disproportionally large, that they took away a considerable share of the elegance of the birds; on this account it is not improbable they were deprived of them by the islanders. Buffon, in his history of birds, says, this beautiful bird is not much 
diffused, it is in general confined to that part of Asia which produces the spiceries, and especially the islands of Arou. It is known also in the part of New Guinea opposite to those islands; but the name which it there receives, Burung Arou, seems to indicate its natal soil. The Bird of Paradise is supposed to subsist on the aromatic productions of these islands; at least it does not live solely on dew. Linnzeus says, it feeds on large buttertlies; and Bontius, that it sometimes preys upon birds. Its ordinary haunt is in the woods, where perching in the trees, the Indians watch it in slender huts, which they attach to the branches, and shoot it with their arrows of reeds. The ancients seem to have been totally unacquainted with the Bird of Paradise, Belon pretends that it was the Phoenix of antiquity; but his opinion is founded on the fabulous qualities of both. The Phonix, too, appeared in Arabia and Egypt, while the Bird of Paradise has remained always attached to the Oriental parts of Asia, which were very little known to the ancients. - The extreme elegance of the tail-feathers of this bird have made them expensive articles of female decoration.

Less Bird of Paradise. (Paradisea Minor.) This differs from the last, in being considerably less, and in having a long flowing feather at the sides, of a much finer texture and colour:

The Magnificent Bird of Paradise. (Paradisea Magnifica.)

The Gorget Bird of Paradise. (Paradisea Nigra.) This is a most splendid and beautiful bird, and likewise extremely rare. Presented by Lady Banks.

Gold-breasted Paradise Bird. (P. Aurea.) A remarkably fine specimen.

King Bird of Paradise. (Pardisea Regia.) 'This superb bird is usually called the King of the Birds of Paradise; but this appellation is drawn from fabulous accounts. Clusius was informed by the mariners, from a tradition which prevailed in the East, that each of the species of the Birds of Paradise had its leader whose 
royal mandates were received with submissive obedience by a numerous train of subjects; that his majesty always Hew above the flock, and issued orders for inspecting and rasting the springs, where they might drink with safety. It inhabits the islands of the Indian Ocean, and returns to New Guinea in the rainy season; feeds on berries, is a solitary bird and is highly valued on account of its rarity and beauty of plumage.

Blackbodied Bird of Paradise. This beantiful and uncommon bird, which does not appear to have been seen by any English writer, is, like the others, a native of the Molucca Islands, but is a rarity even in that country; the plumes being worn only by persons of the first rank; the whole of the head, neck, body, and tail, is a fine black, with a velvet-like gloss, the latter changing in some lights to a rich purple. The bill is long, black, and somewhat hooked; the feathers under the lower mandible reaching a considerable part of its length : from the back of the neck rises a divided tuft of long, thick, close-set feathers, edged with resplendent emerald green; from the sides of the body and wings rise two tufts of long delicate silky feathers, as in the common Bird of Paradise, only smaller, six on each side of which have strong black wire-like terminations about nine inches long, destitute of every appearance of feathers.

Bue Green Bird of Paradise. (Paradisea Virilis).

Golden Bird of Paradise. (Latham's Synopsis, vol. i. page 483).

Superb Bird of Paradise. (Paradisea Superba).

Pair of Birds of Paradise, undescribed.

The Red Bird of Paradise. This beautiful and very eare bird we are acquainted with through the figure in the splendid publication of Oiseaux Dores, in which it is called Me Paradis Rouge: it seems to be nearest allied to the Greater Bird of Paradise, the principal difference being in the colour of the long side feathers which rise under the wiags, being in this of a fine red, and that instead of the long wire feathers in the tail, it 
has two curious appendages resembling fat pieces of po. lished whalebone. This specimen is believed to be the only one ever brought to England.

\section{Black Bird of Paradise. (Paradisea Furcata).} $695)$.

The Grand Hoopoe (Latham's Synopsis, vol. ii. page

(Le Grand Promerops áparemens frises, Buffon, vol. iv. page 472).

This magnificent bird is thus described by Mr. Latham:- "This most extraordinary and beautiful bird is near four feet in length from the tip of the bill to the end of the tail; the body is the size only of a middling pigeon, though much elongated in shape. The bill is three inches long, pretty much curved, and black; the head, hind part of the neck, and upper part of the belly, are of a shining green; the rest of the plumage, on the upper parts, black, mixed with a gloss of changeable viclet, but the wings, in some lights, appear blue; the fore part of the neck, and lower part of the belly, without gloss. The scapular feathers are of a singular construction, the webs on one side of the shaft being exceedingly short, and on the other of a great length; the shape of them falciform; they are of a purplish black colour, with the ends for three quarters of an inch of a most brilliant, gilded, glossy green, though some of them in a different light reflect a blue gloss; beneath each wing rises a thick tuft of feathers eight inches and a half in length, and of; a texture resembling the herring-bone ones in the greater Bird of Paradise."

A pair of New Holland Birds of Paradise. (P. Parkinsonia); one presented by the Countess of Liverpool, the other by Dr. Snith, President of the Limnzean Society.

\section{CUCKOWS (CUCULus.)}

Tun Collecticn contains nearly 40 species of this family. The habits of the common Cuckow are well known, and 
may serve to give a general idea of most of them. They are scattered over most parts of the world. Some of thens are of tine plumage, as the Cupreous, which is an inhabitant of the hottest parts of Africa, where however it is rare; the rich metallic glossy green with which the whole upper parts are covered, can only be equalled by the glowing tints of the Humming Bird.

Royal Cuckow. (C. Regius). This bird is larger than the others : its colour is a beautiful green, and it is distinguished by a pointed crest. This specimen lived seve. ral years in the aviary of Her Royal Highness the Duchess of York, by whose liberality the Museum has been enriched with several curious specimens.

Beneath the above are placed the Barbets, Trogons, and Anis.

\section{WOODPECKER (PICUS.)}

THE birds of this genus climb up and down trees in search of insects, which they transfix and draw out from the clefts of the bark by means of the tongue, which is bony at the end, barbed, and furnished with a curious apparatus of muscles for the purpose of throwing it forward with great force. They build in decaying and dead trees, which they perforate with their hard, wedge-shaped bill. Their feet are very strong, having the toes placed two before and two behind, and in climbing are assisted by the strong pointed feathers of their tail: some of them are found in England. There are upwards of forty in this Case, in which are also a few of the next genus in the Linnzean arrangement, the Sitta, (Nutnach) whose mode of life are much like the Woodpecker, from which they differ in having the toes placed three before and one behind.

\section{KING-FISHER (ALCEDO.)}

THE birds of this family vary much in size; some of them are very splendid in their plumage, in which bright blue is the colour that predominates in the whole tribe, 
They mostly frequent rivers, and feed on fish, which they catch with much dexterity: they swallow their prey whole--their wings are short, yet they fly with great swiftness. The only one found in this country is the common Alcedo Ispida.

The Greeks celebrated this bird by the name of Alcyon, or Halcyon; the epithet Alcyonium was applicable by them to the four days before and after the winter solstice, when the sun shone brilliantly, the sky serene, and the sea smooth and tranquil. It was then the timorous mariners of antiquity ventured to lose sight of shore, and shape their course on the glassy main. The King-fisher is the most esteemed of British Birds for the brilliancy of its colours. It mestles on the banks of rivers and brooks, in holes made by water-rats. Gesner observes, that it can never be tamed, and that it is always wild. Its flesh has the odour of bastard musk, and is very unpalatable food; its fat is reddish; its stomach roomy and flaccid, as in birds of prey; and like them too it discharges by the bill the undigested fragments, scales, and bones, rolled into little balls.

In the same Case are a few of the Jacamars, (Galbula) the plumage of some of which partakes of the metallic lustre of the Humming-Bird.

\section{BEE-EATERS (MEROPS.)}

THE birds of this genus are mostly natives of the Old Continent, few being found in America; but the discovery of New Holland has brought us acquainted with a number of species that were unknown to us before. Their general food is said to be insects, and that they build their nests in holes on the banks of rivers, in the same manner as the King-fisher, to which they seem much alied.

The European Bee-Eater (Merops Apiaster), is a native of many of the warmer parts of Europe. but is rarely seen in the British dominions. It is extremely common in Greece, and the islands of the Archipelago: and in Crete is most plentiful. - It is in this latter island that the curious 
mode of bird-catching, described by Bellonius, is said to be frequently practised with success, viz. a cicada is fastened on a bent pin, or a fish-hook, and tied to a long line. The insect, when thrown from the hand, ascends into the air, and flies with rapidity; the Merops, ever on the watch, seeing the cicada, springs at it, and swallowing the bait, is thus taken by the Cretan boys.

\section{CREEPERS (CERTHA.)}

THESE birds bear a strong resemblance to the HummingBird, as to size and the varied tints of glossy colouring, but the legs are always longer, and the bill in general more bent and sharper at the point. They are likewise dispersed over every part of the wonld, while the Humming-Birds are confined to America.

Their food is insects, which they find under the bark of trees. The Certhia Familiaris, Common Creeper of this country, is an example (says that excellent Ornithologist, Dr. Latham) of the facility with which they run in every direction on the smoothest tree like a fly on a glass window.

\section{HUMMING-BIRDS (TROCHILUS.)}

\section{Say, who can paint}

Like Nature? Can Imagination boast, Amid her gay creation, lnes like these?

THOMSON.

This Case contains nearly one hundred various Humming-Birds, and is allowed to be the finest collection in Europe: such as are known have their names in the order they stand in the system of Linnaus. Of all animated beings (says Bufton) the Fly Bird is the most elegant in form, and superb in colours. The precious stones, polished by art, cannot be compared to this jewel of nature. 
Wer miniature productions are ever the most wonderful: she has placed in it the order of birds, at the bottom of the scale of magnitude; but all the talents that are only shared amongst the others, she has bestowed profusely on this little favourite. The emerald, the ruby, and the topaz, sparkle in its plumage, which is never soled by the dust of the ground. It is inconceivable how much these brilliant birds add to the high finish and beauly of the western landscape. No sooner is the sun risen, than numerous kinds are seen flutering abroad; their wings are so rapid in motion, that it is impossible to discern their colours, except by their glittering; they are never still, but continually visiting flower after flower, and extracting the honey. For this purpose they are furnished with a forked tongue, which enters the cup of the flower, and enables them to sip the nectared tribute; upon this alone they subsist. In their flight they make a buzzing noise, not unlike a spinning-wheel: whence they have their name.

The nests of these birds are not less curious than their form: they are suspended in the air at the extremity of an orange branch, a pomegranate, or a citron tree, and sometimes even to a straw pendant from a hut, if they find one convenient for the purpose. The female is the architect, while the male goes in quest of materials, such as fine cotton, moss, and the fibres of vegetables. The nest is about the size of half a walnut. They lay two eggs at a time, and never more, in appearance like small peas, as white as snow, with here and there a yellow speck. The time of incubation continues twelve days, at the end of which the young ones appear, being then not larger than a blue-bottle fly. "I conld never perceive (says Father Dutertre) how the mother fed them, except that she presented the tongue covered entirely with honey extranled from flowers." "Those who have tried to feed them with syrups conld not keep them alive more than a few weeks; these aliments, though of easy digestion, are very different from the delicate nectar collected from the fresh blossoms. It has been alleged by various naturalists, that during the winter season they remain tornid, suspended by the bill from the bark of a tree, and awa- 
kened into life when the flowers begin to blow; but these fictions are rejected; for Catesby saw them through the year at St. Domingo and Mexico, where nature never entirely loses her bloom. Sloane says the same of Jamaica, only that they are more numerous after the rainy season; and prior to both, Marcgrave mentions them as being frequent the whole year in the woods of Brazil. The method of obtaining these minute birds is to shoot them with sand, or by means of the trunk-gun; they will allow one to approach within tive or six paces of them. It is easy to lay hold of the little creature while it hums at the blossom. It dies soon after it is caught, and serves to decorate the Indian girls, who wear two of these charming birds as pendants from their ears. The Indians, indeed, are so struck and dazzled with the brilliancy of their various hues, that they have named them the Beams, or Locks of the Sun. Such is the history of this little being, who flutters from flower to flower, breathes their freshness, wantons on the wings of the cooling zephyrs, sips the nectar of a thousand sweets, and resides in climes where reigns the beauty of eternal spring.

In the Case with these birds are specimens of their nests, and of their curiously minute eggs.

\section{WATER-FOWL. (Order Anseres.)}

WE are now arrived at the third Order in the Linnæan classification, called Anseres. The whole of the birds in this order have webbed feet, and reside principally on the water.

\section{ANAS (Swans, GeEse, and DucKs.)}

THE birds of this numerous and useful family, of which there are upwards of eighty species in this collection, consisting of great variety of Swans, Geese, Ducks, Teals, and Widgeons, from every part of the world, are arranged in eight Cases, and are named as far as known. The Black Swan from New Holland; the Egyptian, Canada, 
Brent, Bean, and Bernacle Geese, with several curious and beautiful Ducks were all from the aviary at Frogmore, and were graciously presented to the Museum by Her Majesty, to whose condescension and liberality I am indebted for many of the finest subjects of natural history in the collection.

The Spur-winged Geese. (Anas Gambensis.) Male and female; and the highly curious non-descript species, having a very high crest-like protuberance, the whole length of the upper mandible: were lately sent from the interior of Africa, on the banks of the Gambia, by $\mathbf{M}$. de Bonay, of Senegal, by whose exertions this collection has been considerably enriched, by the addition of many extremely curious and hitherto unknown quadrupeds and birds.

Eider Duck. (A. Mollissima.) There is a pair of these birds, with their nest, their eggs, and some specicimens of their young. They are well known, on account of the valuable down which they pluck from their breasts and of which they make their nests.

The Chinese or Mandarine Duck. (Anas Galericulata.) Which is perhaps the most beautiful of this elegant and highly useful family.

\section{The Pintail Duck. (Anas Acuta.)}

The Gadwall. (A. Strepera.)

The Gargany. (A Querquedula)

The Tufted Duck. (A. Fuligula.)

The Harlequin Duck. (A. Histriomia.)

The Buffel-headed Duck, and some undescribed species.

Under a separate glass shade is a beautiful specimen of this genus: being a goose of varied plumage, not larger than a pigeon, which was brought from the river Gambia in Senegal; it was presented to the Museum by Lord Darnley. 


\section{AUKS AND GUILLEMOTS.}

IN this Case are the whole of the birds of these families, found in Great Britain with their eggs and young; they were collected in the summer of 1812 , in the North of Scotland and the Orkney Islands. Many of them are extremely rare. Besifles these there is

The Treflet Arle. (Alca Cirrata.) This curious bird was talken by Capt. Cook at Kamtschatka, and is the only specimen in any public collection.

\section{PENGUINS (APTENODYTES.)}

The Patagonian Pengain. (Aptenodytes Patachonia.) These highly curious birds seem to form the connecting link between the feathered and scaly race. It is upwards of three feet in height; its tin-like legs being placed at the extreme end of its body, it can stand in no position but quite upright; in place of wings it has two dangling flaps, which when in the water serve as fins, but are of no use on shore, as it is totally incapable of flight; it seldom comes to land, but for the purpose of depositing its eggs ; it is then so easily taken, that Capt. Cook says, a man might kill with a stick, in a few hours, as many as would load a large boat.

The Crested Penguin. (Aptenodytes Chrysocome.)

The Little Penguin. (A. Minor.) Inhabits New Zealand.

\section{Petrels (Procellaria.)}

A very extensive collection of these remarkable marine birds, principally collected by Captain Cook; they live chiefly at sea, and seldom approach land, except at the breeding season; they have the faculty of spouting a large quantity of oil from their bill to a considerable distance, and feed on the fat of dead whales and other fish. 
The Wandering Albatross, or Marn-of-War Bird. (Diomedea Exulans.) This bird is frequenty mentioned by navigators, as being met with several hundred leagues from land: in its figure and manner it bears a strong resemblance to the Gulls, but is of such an extraordinary size as to measure 13 feet from the tip of one wing to the other.-Presented by the Marquis of Buckingham.

\section{PELICANS (PELICANÚS.)}

THE whole of these are extremely expert in catching fish, and are sometimes tamed for that purpose, when their labours amply repay their keeper for the trouble of their education.

The Great White Pelicar. (Pelicanus Onocrotalus.) Is a native of Asia, Africa, and South America; it is five feet long, of a white colour, slightly inclining to rosy; it is said to build its nest in dry sandy deserts, where it carries water in its immense pouch for its young, from which probably arose the fabulous account of their feeding their young with their blood, and of their being made an emblem of parental affertion by the ancients.

The Lesser Frigate Pelican. (Pelicanus Minor.) The length of this bird is about two feet eight inches; the extent of wing more than seven feet; the colour, sooty black; the pouch or gullet, bright scarlet. Perhaps none of the feathered tribe continue so much on the wing as this; they are met with at sea, at an immense distance from any land, and generally flying very high.

Red-faced Shass. (Pelicanus Uricl.) From Kamschatka.

\section{Corvorant. (Pelicanus Carbo.)}

\section{Shag. (Pelicanus Graculus.)}

Tufted Shag of the Bass Island. Two of these birds, both females, were shot by myself, on the 9 th of May, 1807 , on the Bass Island, in the Frith of Forth, where they are believed to breed and remain the whole year; 
the general appearance, both in size and colour, was nearly similar to the common Shag, and the number of tail feathers the same; the most striking difference arises from a singular tuft of forty-six narrow and nearly straight feathers, two inches long, standing close together upright, with a slight bend forward on the front of the forehead, in so remarkable a way as at once to distinguish it from any described species. The origin of the lower mandible, and the naked - pouch under the throat, was of a bright yellow, approaching to orange, with small spots of black; the irides, a beautiful grass green, and it had no bare space round the eyes; the ovaries of both specimens contained a number of small eggs, and from the account of the person who takes the young Gannets at the Bass, and who possesses considerable knowledge of the birds that visit it, there can be little doubt of its being a new species, and of its rearing its young in the inaccessible precipices of that island; and it is somewhat surprising that it should have remained so long unnoticed in the neighbourhnod of so many naturalists and ornithologists as Edinburgh contains : the flesh was eaten, and found to be entirely destitute of that rancid smell and taste that affect the generality of the cormorant tribe. I have observed what appeared to me to be the sime species, on Lambay Island, on the east coast of Ireland.

Gannets, or Soland Geese. (Pelicanus Bassanus.) This beautiful species of Pelican is diffused over most parts of the ocean, but seldom approaches the land except at the breeding season; it received its trivial name from its frequenting, in immense quantities, the Bass Island, in the Frith of Forth, on the east coast of Scotland. In the spring of 1807 , I visited this celebrated rock (once the state prison of Scotland,) accompanied by Arthur Strickland, Esq. of York, for the purpose of procuring specimens of the various water-fowl that annually resort to it at that season of the year for security, during the important business of rearing their young.

We arrived under the towering and tremendous projecting cliffs of the east end, just before sunrise, and approached as silent as possible. At a little distance, the precipice appeared as if composed of chalk; but on a nearer 
approach, we discovered that this effect was produced by the excrement, as well as by the white plumage of the innumerable water-fowl that covered the cliffs. The whole of the various families were just awake, and preparing, by shaking their feathers and pluming their wings, for the busy occupation of the coming day. After attentively observing them for some time, on a given signal we fired our guns, and the boatmen shouted altogether, when such a scene took place as I had never witnessed: in an instant our ears were assailed and deafened by the varied and continued cries of at least 100,000 birds-Gannets, Cormorants, Shags, Puffins, Razor-Bills, Guillemots, and the various kinds of Gulls, raised their discordant notes at the same moment, and by their numbers formed a canopy over our heads that darkened the air, while their ex. crement, occasioned by the sudden alarm we had put them in, fell in a thick shower on every side. After the confusion had somewhat subsided, we proceeded to the west end of the island, and ascending to the summit, found ourselves above the cliffs, where the Gannets were sitting, close to each other, on their eggs. We crept cautiously down amongst them, and so attentive were they to their occupation of sitting, that it was with dificulty they could be forced from their eggs, though at other times they are extremely shy.-They lay but one, which is perfectly white, and in shape and size nearly resembles that of a crocodile; it is placed on the bare rock, surrounded by a circle of wet sea-weed, which is constantly replenished by the male as it becomes dry. I had been told, but doubted the fact, that during the time of incubation the female holds the egg in her foot; this I found to be the case.

In a visit I made in the August following, the young were many of them gone: but still I had an opportunity of examining them in their different ages, previous to their leaving the island. When first produced from the egg, they are black and very ugly; in a few days they become covered by a resplendent white down; in about a month afterwards, their first feathers begin to appear; they are black the first year, spotted with whitethe second, and on the third attain their mature plumage. The spe. cimens are in the regutar progression. 


\section{DIVERS (COLYMUS.)}

Imber Divers. (C. Imner.) Male and female, shot in the Long Hope, Isle of Hoy.

Red-throated Divers. (C. Septentrionalis.) Male and female, very rare, with their eggs; taken in Hoy.

Black-throated Diver. (C. Arcticus.)

\section{BRITISH GREBES.}

A complete collection of the birds of this family, containing male and female of every species known in Great Britain; they inhabit still water, and several of them make noating vests, and breed in the fens of Lincolnshire and the meres of Cheshire.

\section{GULLS (LARUS.)}

NEARLY every species of the British Gulls with their eggss and young, are contained in this Case; they were collected during two voyages to the Orkney and Shetland Isles, undertaken in the spring and autumn of 1312 , for the purpose of investigating the natural productions of those sequestered countries.

The principal breeding place in Great Britain, of the larger brown species called the Skwa Gull, (Larus Cataractes ) is on the top of a mountain in the secluded isle of Foula, distant about eighteen leagues from the Orkneys. We visited this romantic spot early in the month of July, and received a hearty welcome from the poor but hospitable inhabitants, to whom the sight of a stranger is an unusual occurrence; on learning the object of our visit, the person who acts as schoolmaster and minister, for they have no resident clergyman, offered to atiend us to the top of the hill, where the Bonxies (the Shetland name of the Skua) were then hatching their young. We had scarcely arrived at the place before we were attacked 
in the most furious manner by these enraged and formidable birds, who flew with the utmost violence in the direction of our eyes, and were not at all intimidated by the report of our guns, or the numbers that we killed: a large dog that we took with us was so roughly treated, that it was obliged to come to us for assistance, and my son received a violent blow on the back of his head, whilst stooping to secure a bird he had wounded. They lay their eggs, four in number, of a dull olive colour with large dusky spots, on the ground, among the short heath and grass, and it was with difficulty we could find them; the young were covered with a fine cinnamon-coloured down, exceedingly soft and beautiful. We brought some of them alive to England; they were very tame and affectionate, but were much longer in getting their first feathers, than the young of any other of the Gulls; their voice was very remarkable, strongly resembling the horns used by the guards of the mail-coaches.

The Great Black-backed Gull.

(Larus Marinus.) This is the largest of the genus, and is when living a beautiful species; it is a northern bird, but during winter in severe weather is occasionally seen on our shores; it does not breed in England, nor has its place or manner of incubation been described. We found it on the Souliskerry, a small uninhabited and desert island, about ten leagues to the west of the Orkneys, in great numbers, so that it was difficult to walk in some places without treading on their eggs, which are laid on the bare flat ground with a few weeds round them, four in number, of an olive colour with brown blotches, nearly the size of those of a goose, but of a rounder shape; the young are covered with a fine grey down, spotted with black, and are scarcely to be distinguished from those of the lesser black-backed, which breed on the same retired and melancholy spot, but in separate places. This island is solely in the possession of myriads of sea-fowl, and the great seal which breed there in undisturbed security, in the month of November; we saw several hundred of their skeletons, some of which were ten feet long. Till our visit, the island had not been disturbed by human foot for several years, owing to the 
distance from any human habitation, and the difficulty of landing.

Arctic Gulls. (Larus Parasiticus.) This is a fierce and rapacious species, attacking whatever approaches its nest; and the arts they make use of to decoy an intruder from its neighbourhood, exceed those of any other bird. They never fish for themselves like the other gulls, but watch the Kittiwake, the common gull, \&c. and as soon as they observe they have taken their prey, attack them, and by striking them on the back, oblige them to disgorge the fish they havejust taken; and, with wonderful adroitness and rapidity, catch it a few yards in its descent toward the water.

The Black-toed Guil. (Laurus Cripidatus.) Is a rare British bird; shot in Lincolnshire. Presented by Sir Joseph Banks.

The Black Skimmer. (Rhynchops Nigra.) Is remarkable for its singular bill, the lower mandible of which projects considerably beyond the upper, into which it fits like a razor in its handle. It inhabits America and Asia, and is continually flying about and skimming over water, out of which it scoops small fish with its oddly projecting bill.

\section{WADERS;}

Birds that derive their subsistence from water, but which do not swim. (Order Grallæ.)

The Red Flamingo. (Phœnicopterus Ruber.) One of the most remarkable birds of this order, the body not being much larger than that of a Duck; while the height, owing to its extremely long legs and neck, is upwards of four feet. The colour in the full grown bird is bright scarlet, except the tips of the quills, which are black; the bill differs from every other bird, and when 
used in feeding is turned the contrary way, so that the top of the head comes near the ground. They inhabit Africa and South America, and I am informed by a friend who has just reinued from Spain, that he killed one near Cadiz, and that they are there brought to the market of that city, and sold as food.

Their mest is of mud, in the form of a ligh cone, indented on the top to receive the eggs; across this the bird stands during the time of incubation.

WHITE SPOONBILLS. (PLATALEA LEUCORODEA.)

THE bill of this remarkable species is long, and toward the extremity spread out in a spoon-like form. They were formerly not uncommon in this island; but since the introduction of fire-arms, and the improvement that has gradually taken place in the art of shooting, they have, with other birds then found in plenty, left this country for others more retired.

Rose-coloured Spoonbills. (Platalea Ajaja.) These beautiful birds are natives of South America; the one with bright crimson plumage is considered a new species; in the same case is the Boat Bill (Cancroma Cochlearia.)

\section{JABIRU。 (MYCTERIA.)}

American Jabiru. (Mycteria Americana.) This extraordinary and majestic bird is nearly six feet long; it inhabits the extensive marshes of South America, feeding on tish, which it devours in large quantities; it builds its nest in trees which hang over the water, and lays two eggs. Presented by Lord Teignmouth.

Senegal Jabiru. (Mycteria Senegalensis.) Measures upwards of six feet from the bill to the toes; it is the 
only one known in this country; it was first described, from an imperfect specimen, by Dr. Shaw, in the fifth volume of the Linnæan Trausactions. It was lately received from the river, Gambia, and presented, with several other rare and valuable birds of Africa, by Henry Brogden, Esq.

A non-descript species of Jabiru, the native country unknown; it lived some time in a state of confinement in Exeter 'Change, and was fed with fish.

\section{CRANES. (ARDEA.)}

Numidian Crane, or Demoiselle. (Ardea Virgo.) This beautiful bird has received the name of Demoiselle, or Miss, on account of its elegant form, its rich garb, and its affected airs. It was famous, amongst the ancients, though it was little known or seen in Greece or Italy.

A large species of Crane, from New Holland; seems nearly allied to Ardea Antigone of Linnæus. Length, five feet nine inches; breadth of the wing, six feet three inches; general colour, bluish ash, except the quills and chin, which are black; top of the head without feather, ash colour; the regions of the eyes and back of the meck covered by a carunculated skin of bright vermilion colour. Presented by Dr. Munro, jun. who received it from New Holland, where it was killed by Dr. Jamieson.

Great White Heron. (A. Alba.)

Green Heron. (A. Virescens.)

Cinereous Herons. (A. Cyanopus.) Male and female.

Gigantic Heron. (Ardea Dubia.) A fine specimen of this singular and highly curious bird, which, when standing upright, measures upwards of six feet; it is common in India and Africa, and partly domesticated and protected on account of the quantity of pernicions reptiles it destroys; the mouth is so wide that it with ease can swallow a cat whole, and its voracious appetite 
is scarcely to be satisfied. This remarkable bird was kept in the menagerie of her Royal Highness the Duchess of York several years, and when at ease, usually placed itself in the grotesque position in which it is preserved.

Pair of Crowned African Cranes. (Ardea Pavonia.) 'These owe their title of Royal to a sort of crown which decorates their head. They inhabit Africa, especially Gambia, the Gold Coast, and Cape Verd. They are of a gentle and pacific disposition; their defence is their stature, and the rapidity with which they run and fly. They are less afraid of man than of their other enemies: we are assured, that at Cape Verd these birds are half domesticated, and that they come into the court-yards to eat grain with the Guinea fowls. Their cry is like the peacock's. 'The Portuguese, in the 15 th century, it is supposed, were the first people that brought these birds into Europe, at the time they discovered the Gold Coast.

In the bottom of this Case is the Bull Frog of Ame. rica. (Rana Maxima.)

Agrami Heron. (A. Agami.) Is a beautiful bird, inhabiting the swamps of Cayenne. Few birds have more splendid plumage.

The Striated Heron is likewise from Cayenne, and, when closely examined, has much beauty of plumage.

Tiger Bittern. (A. Tigrina.) Remarkable for the strong contrast of its rich colouring, which resembles the animal from which it is named.

Little Bittern. (A. Minuta.) Shot in England, where it has lately been several times killed.

Minute Bittern. (A. Exilis.) The smallest of the genus, only eleven inches long: From Monte Video.

Common Heron. (A. Major.)

Great Egret. (A. Egretta.)

Little Egret. (A. Garzetta.) This very beantifu! bird was formerly very common in England.

D 2 
Blue Heron. (A. Corulea.)

Squacco Heron. (A. Comata.)

Snowy Heron. (A. Candidissima.)

Malacca Heron. (A. Malaccensis.)

Bittern. (A. Stellaris.)

The White Stork. (Ardea Ciconia.) These birds are partly domesticated in Holland, and are held sacred by the inhabitants for their use in destroying frogs; lizards, \&c. They have been occasionally killed in Britain.

\section{IBIS. (TAntalus.)}

Sacred Ibis. This remarkable bird, which is the first exhibited in this country, has just been received from Africa, and lately described by a French naturalist as the celebrated sacred bird of the Egyptians (the identity of which has long been disputed;) and there is every reason to believe it to be the species of which the mummies, in the bird-pits at Saccarra, are composed.

It has been examined at the house of Sir Joseph Banks with the most perfect mummy known, in which the feathers are still entire, and the result left no doubt on the minds of the gentlemen present, of its being the true species of Ibis, held sacred and preserved by the ancient Egyptians. See the Mrommy.

The Glossy Ibis. (T. Igneus.) This was lately killed in Wales. It was likewise shot a few years since in Lancashire.

Egyptian Ibis. (T. Ibis.) This large species is what most naturalists have considered as the sacred; but on examination with those mummies that have come under my observation, I find it much longer, and the bill very different from any of them.

Scarlet Ibis. ('T. Ruber.) Inhabits the borders of the great lakes and rivers of South America: The colour 
of the whole bird, except the tips of its wings (which are black) is bright scarlet. It feeds on small insects and crabs, and will breed in a domestic state.

Brown Ibis. (T. Fascus.)

Black-faced Ibis. (T. Melanopis.)

\section{CURLEWS. (SCOLOPAX.)}

Common Curlew. (Scolopax Arquata.) With its nest and eggs, taken on the moors between Edinburgh and the falls of the Clyde.

The young one was kept alive for some time; its food was small pieces of raw flesh; the bill, at their exclusion, is little larger than our domestic fowls, and it is not till the bird is nearly at its growth that it attaius any considerable length.

In this Case are a number of the Scopolax genus, some of which are rare. Almost all of them are delicacies for the table; among which are the Woodcock, Snipes, and other birds equally well known; of all of which there are specimens. Under a separate glass covering are a Woodcock with its entire brood.

The Tringa genus also includes many birds that are well known, and esteemed as articles of luxurious living. Among them are the Plover, the Lapwing or Bastard Plover, the Sec Dottrel, and others.

Sandpiper. (Tringa.) Many of these are natives of our own shores, where they run in quest of their food with arnazing celerity, uttering at the same time a sharp, shrill cry-whence their name.

Amongst the most remarkable is the

Ruff. (T. Pugnax.) Its British name is taken from the remarkable feathers that stand upon its neck and 
shoulders. They are taken in large quantities in the spring, in the fens of Lincolnshire, and fattened on bread and milk for the London markets: owing to the strong propensity of the males to fighting, they are obliged to be kept in the dark.

\section{Grey Phalarope. (T. Lobata.)}

Red Phalarope. (T. Hyperborea.) With its egg taken at Sanda in Orkney.

Little Sandpiper. (T. Pusilla.) The three last are among the most rare of the British birds, and are in bell glasses.

\section{PLOVER. (ChARADRIUS.)}

A number of rare, and several new species of this genus of birds are in this Case.

Austrian Pratencole. (Glareola Austriaca.) This extremely rare British bird was killed in September, 1812 , in the Isle of Unst, within three miles of the northern extremity of Great Britain.

Cream-coloured Plover. A beautiful specimen of this rare bird is under a separate glass shade.

Scooping Avocet. (Recuvirostra Avocetta.) This curious bird derives its British name from the circumstance of its scooping the worms and insects on which it feeds, out of the sand and mud, with its curved bill.

White Sheath Bill. (Vaginalis Alba.) This curious bird, the only one of the genus and the only specimen presumed to be in Britain, was brought from New Zealand by Capt. Cook, and has, with many other valuable subjects of Ornithology collected during the voyages of 
that celebrated circumnavigator, been lately added to this Museum by the liberality of the Royal College of Surgeons.

\section{JACANA. (PARRA;) and RALLUS. (RAIL.)}

In this Case are several species of these birds, remarkable for the extreme size of their feet, by which they are enabled to run over the marshy ground and swamps which they inhabit: some of them are also remarkable for the sharp spurs with which the shoulders are armed. They are natives of the warmer parts of India, Africa, and America. The habits of bolh genera are very similar.

\section{PSOPHIA. (TRUMPETER.)}

Gold-breasted Trumpeter. (13.Crepitans.) This birl inhabits Brasil and Guiana; and is remankable for the harsh noise, not unlike a child's trumpet, with which it annoys people.

BIRDS HAVING AFEINITY TO DOMESTIC FOWLS.

(Order 5th Gallina.)

BUSTARDS. (OTIS.)

A fine collection of the birds of this genus, from Africa and India, several of them are undescribed, some of them brought by Sir Joseph Banks and Captain Cook, in their first voyage of discovery.

The Great Bustard. (Otis Tarda.) This is the largest of the British land birls, weighing $28 \mathrm{lb}$.; it was formerly common, but the few now remaining of this noble species in England, seem to be contined to the Downs in Norfolk. 
Little Bustard. (Otis Tetrix.) Male; this is one of the rarest British birds.

\section{OSTRICH. (STRUTHIO.)}

Black Ostrich. (S. Camelus.) Male; a full grown specimen, having attained its complete plumage; from the menagerie of Mr. Polito, at Exeter 'Change. A most superb bird of this kind; perhaps the finest ever brought to Europe; it reaches 11 feet in height.

Cassowary. (\$. Casuarius.) Fine specimen of the toale of this highly curious bird.

Great Emu, or New Holland Cassowary. (S. Nova Hollandia.) Upwards of 7 feet high.

Lesser Emu, a distinct species, not half the size of the above.

American, or Three-Toed Ostrich. (S. Rhea.)

\section{PEACOCK. (PAVO.)}

Japar Peacock. (P. Muticus.) This magnificent specimen was presented to the Museum by Her Majesty: it is considered equal, if not superior, to any bird of the species that has yet been seen in England.

A beautiful species of Peacock, from the Island of Java, not described by any Naturalist; presented by the Countess of Darnley.

An extremely splendid bird, nearly the size of the common Turkey, to which it is allied; it was brought from the Bay of Honduras, as a present for Sir Henry Halford, who gave it to the Museum. It is not noticed by any writer.

The Wild Turkey of America. Also presented by the Queen. 


\section{CURASSOWS. (CRAX.)}

Crested Curassows. (Crax Alector.) Male and fe. male. Inhabits Surinam and other warm parts of S. Ame rica; its size is nearly that of a Turkey, the male is black, but in the female the feathers of the head and neck are black and white; and the whole of the body is a rich mixture of fine cream-colour and black; the head is ornamented with an erect crest, each feather being bent a little forward, which gives the bird a very majestic appearance. They are domesticated in South America, and are said to be excellent food.

Cashew Curassow. (Crax Pauxi.) It is a native of New Spain, and is remarkable for the singular blue pearshaped protuberance on the front of the head; they are easily tamed; I kept one for some time in a poultry yard, where it associated with common fowls in the most friendly manner.

In this Case are two others of the family, both from Cayenne, not yet described.

\section{PHEASAN'TS。(Phasianus.)}

Argus Pheasant, or Luen. (Phasianus Argus). This superb and majestic bird was first described by Edwards, in the 55th volume of the Philosophical Transactions, who says, "It is the largest of the pheasant genus yet known, being in size equal to a full grown turkey." The wings and tail are besprinkled with a multitude of round spots like eyes; whence it has received the nane of Argus. The feathers in the midnle of the tail are very long, and project much beyond the rest. (A much longer, and equally beautiful feather, of an unknown species of Chinese Pheasant, five feet long, is in the same Case.) Its head is covered with a double crest. It has been doubted whether this bird had not originally more 
than two long tail-feathers; this, however, on examina tion of the rump, seems never to have been the case. Mr. Pennant describes it as having spurs like the common cock, but this also appears to be an error; for this bird, although a male, and of full growth, has not the slightest appearance of them.-This extraordinary bird, with its wings extended, measures eighteen feet in circumference. It is a native of the North of China.

African Pheasant. (P. Africanus.) This bird is a native of Senegal, and differs so much from the rest of the family, as scarcely to deserve a place with them.

\section{Crested Pheasant. (P. Cristatus.) Native of South} America.

\section{BRITISH PHEASANTS. (PhasianUs.)}

None of the birds of this family are originally natives of Britain, but as they now brave our winter, and breed with us, they may be considered as naturalized.

The Golden or Painted Pheasant, (P. Pictus.) Of the brilliancy with which nature so often decorates the feathered tribe, the Golden Pheasant is one of the most striking examples; a bird of which the colours are so powerfully lucid, as to dazale in a full light the eyes of the spectator, and can only be exceeded by the polished lustre of the Humming-bird; even the Peacock himself, with all his gaudy plumage, falls short in the comparison. This splendid bird is now bred in this country, and will stand our winters tolerably well.

The female was presented to the Museum by Her Majesty.

\section{Common Pherusant. (P. Colchicus.)}

The Ringed Pheasunt.. (P. Colchicus var.) Presented by the Bishop of Salisbury.

A pair of Bohemian Pheasants, presented by Lady Reade, who was the first person that succeeded in breeding this species in England. 
White variety of the common Pheasant.

Pied variety of the common Pheasant; a beautiful bird, presented by Colonel Taylor of Windsor Castle.

A beautiful pair of Silver Pheasrents. (P. Nycthemerus.) Presented by the Bishop of Durham.

A pair of Indian Fowls, bred in the woods of $\mathrm{R}$. Hammond, Esq. in Norfolk.

Wild Cock of India, or Jungle Cock. (P. Varius.) This beautiful bird is supposed to be the parent, or original stock, of all the varieties of our domestic poultry; it is placed under a bell glass in the recess.

\section{WOOD GROUS, OR CAPPERCAILE.}

\section{(TETRAOUROGALUUS.)}

THE male of this noble species of game is nearly as large as a Turkey, but the female is considerably smaller. They were formerly found in Ireland and Scotland, but are now believed to be extinct, as I hear of no authentic account of any having been met with for several years.

They are found in various parts of the Old Continent, principally in the northern, in the large pine forests; and many of them are sent every winter from Sweden to London, and used at the tables of the great, being by many considered a luxury, although they are said to taste strong of the pine buds on which they feed.

\section{BRITISH GAME.}

Pair of Red Grous. (Tetrao Scoticus.) These birds are streaked cross-wise with black and reddish brown.

Pair of the Black Grous. (T. Tetrix.) This species are almost entirely black; the tail is forked and curved. 
Pair of the Ptarmigan. (T. Lagopus.) These birds are much esteemed for the table: they are almost white.

The White Hare. (Lepus Variabilis.) This species is found on the northern hills of Europe, Asia, and America, from whence in the winter it migrates to the plains in troops, and returns in spring. The limbs and tail are shorter than the common hare: they change from a reddish grey to white in the winter, except the tips of the ears, which are black.

A great variety of the birds of this genus from all parts of the world are here; many of them are extremely rare, and some new; among them are the

Spotted Grouse. (Tetrao Canadensis.) Male and female.

Pinnated Grouse. (T. Cupido.)

Hazel Grouse. (T. Bonasia.) Male and female.

Red-legged Partridge. (T. Rufus.) These were presented by the Queen.

Pearl Partridges. (T. Perlatus.) Male and female.

Senegal Partridges. (T. Bicalcaratus.)

Maryland Quail. (T. Marilandus.)

Crested Quail. (T. Cristatus.)

And the Common Quail. (T. Coturnix.)

The Common Partridge and Young, are beautifully preserved, under a large glass shade.

\section{BIRDS HAVING AFFINITY TO SPARROWS.}

(Sixth Order, Passeres.)

\section{PIGEONS. (Columba.)}

In this Case are a great variety of the Pigeons and Doves from almost every part of the world, with their names affixed to them. 
Ihe Bronzed-winged Pigcon. (C. Chalcoptera.) is a beautiful species, inhabiting New Holland; the covert of its wings, exhibiting all the prismatic colours on a metallic ground.

The beautiful White Fan-tailed Dove was presented by her Majesty, who received it from Walcheren.

Several beautiful and rare birds of this family, collected during Cook's voyages.

Crowned Pigeon. (Columbo Coronata.) The gigantic size of this species, which is not far short of a turkey, has caused some naturalists to place it rather among the gallinaceous tribe than in the genus Columba. Its characters are however so clearly and decisively marked, as to declare at once its proper genus. It is undoubtedly one of the most elegant of hirds, and is a native of the Molucca Islands. Its voice resembles that of the Wood Pigeon, but in so loud and hoarse a tone, that it is recorded of some of Mons. Bougainville's sailors, that they were greatly alarmed on hearing it for the first time in the unfrequented spots of some islands on which they landed; supposing it to have proceeded from the savage cries of hostile and concealed natives. This bird is frequently brought to Europe alive, and is considered as one of the greatest ornaments of the menagerie. It was presented to the Proprietor, with other articles, by her Royal Highness the Princess Charlotte of Wales.

The Ground Dove. (C. Minuta.) Is a strong contrast to the last, being only five inches long; it is found in several of the West India Islands; but cannot be tamed.

LARKS. (ALAUDA.)

AND

STARLING。(STERNUS.)

THE birds of these families are not so numerous as many of the smaller kinds; almost all that are known sre in this collection. 


\section{2}

\section{THRUSHES. (TURDUS.)}

$\triangle N D$

\section{CHATTERERS. (AMPELIS.)}

THis Case contains about 40 species of the Thrustes and Chatterers. The first are not remarkable in general for the splendour of plumage, though some strong exceptions will be observed in this collection; but the richness of their melody makes ample amends. One species, the Mocking Bird of America (Turdus Polyglottus), deserves particular notice; without any exterior attractions, it possesses faculties which renders it one of the greatest objects of curiosity and admiration among the feathered tribes. It is about the size of a thrush. Its natural notes are musical and solemn; but it likewise possesses the singular power of assuming the tones of every other animal, whether quadruped or bird. It seems to divert itself with alternately alluring or terrifying other birds, and to sport with their hopes and their fears. Sometimes it entices them with the call of their mates, and on their approach terrifies them with the scream of the eagle, or some other bird of prey. It frequents the habitatious of mankind, and is easily domesticated; it builds its nest in the fruit-trees near the houses of the planters; and sitting sometimes most of the night on the tops of their chimneys, assumes its own native melody, and pours forth the sweetest and most varied strains. The savages call it Cencontlatolli, or Four Hundred Languages. It is found in Carolina, Jamaica, New Spain, \&c. In Jamaica, it is very common in the Savamnahs, where it perches on the highest trees to chant its song.

The Glossy Thrush. (T. IEneus.) Is a magnificent species, near 18 inches long, of the most shining and vivid colour, which clsanges as seen in different lights.

The Chatterers are mostly natives of South America, and remarkable for the rich and varied tints of their feathers. 
BUNTINGS. (EMRERIZA.)

ABOUT seventy birds of the above species are collected together in this Case, all properly named. The Grosbeaks feed principally on hard seeds, which their strong bills enable them easily to open. The Bull-hinch, which is one of the species, is an illustration of their powers. Many of them are inhabitants of the cold parts of Europe and America.

The Buntings are likewise seed-birds, and have a twoth-like process in the upper mandible, which enables them to split their food with great facility. In this genus are included the several species of Whidah Birds, remarkable for their elegance and great lengh of tail.

\section{BRITISH GROSBEAKS, FINCHES, AND BUNT- INGS.}

THIs Case contains a complete collection of the above birds, in the most beautiful preservation, many of them have their nest and eggs.

\section{TANAGER。(TANAGRA.) \\ AN D}

FINCHES。(FINGILLA:)

ABOU $\mathrm{T}$ eighty of these are contained in this Case. The Tanagers are mostly natives of South Anerica, and no family of birds exhibit a greater diversity of splendid colours. They, as well as the Finches, feed on grain and seed, and are often troublesome and destructive to the plantations, in whose neighbourhood they abound. Many of these are not yet described, but others will be recognised as familiar acquaintance: among them are the Chaffinch, the Goldfinch, the Canary Bird, the Linnet, the Sparrow, and others. 


\section{FLY-CATCHERS. (MusCICAPA.)}

THE birds of this genus are perhaps more universally dispersed over every part of the globe than any other. Their food is entirely insects, which, but for the multitudes that are consumed by them, would render some countries unfit for human residence: about one hundred species are described.

\section{WARBLERS. (MOTACILIA.)}

Thrs genus is more numerous than any other of birds. Dr. Latham, in his excel!ent work, "The general Synopsis of Birds," describes one hundred and ninety-eight species. The major part of them inhabit the warmer countries, where insects, their proper food, abound. They are in general not remarkable for gaiety of plumage, but their melody amply compensates for their deficiency in that respect.

The Nightingale. (Motacilla Luscina.) Though com-, mon in this country, never visits the northern parts of our island, and is seldom seen but in the neighbourhood of London and the western counties. The following description of the varied song of this unrivalled bird, is taken from the ingenious author of the Histoire des Oiseaux:- "The leader of the rernal chorus begins with a low and timid voice, and he prepares for the hymn to nature by essaying his powers and attuning his organs; by degrees the sound opens and swells, it bursts with loud and vivid flashes, it flows with smooth volubility, it faints and murmurs, it shakes with rapid and violent articulations: the soft breathings of love and joy are poured from its inmost soul, and every heart beats in unison and melts with delicious languor. But this continued richness might satiate the ear; the strains are at times relieved by pruses, which bestow dignity and elevation. The mild silence of evening heightens the general effect, and not a rival interrupts the solemn scene." They begin to build in May. 
Taylor Bird. (M. Sutoria.) This bird is much regarded on account of the curious and extraordinary conatruction of its nest, (a specimen of which accompanies the bird.) The little fabric is formed of leaves, which the bird sews together with vegetable fibres, using its beak as a needle.

\section{MANAKIN.(PIPRA。) TITMICE。(PARUs.)}

AND

\section{SWALLOWS. (HIRUNDO.)}

The Manakins, at first sight, resemble the next genus, or Titmice. They are mostly natives of South America, and are in general beautiful in their colours. The most remarkable species is the Cock of the Rock, or Crested Manakin (Pipra Rupicola.) Though this bird is of an uniform orange colour, it is one of the most beautiful of South America. They are found in great numbers on the mountain Luca, near Oyapoc, and on the mountain Couronaye, near the river Aprouack. They are esteemed for the sake of their plumage, and are very scarce and dear; because the savages, either from superstition or fear, will not venture into the dark caverns where they lodge.

The Titmice are a very active and fertile race, laying from eighteen to twenty eggs at one hatch.

They feed on fruit, seeds, and insects, and a few on flesh; most of them are fond of the brains of other birds, which they get at by cleaving the skull of such as they find dead. Several are natives of Britain, and are an extremely entertaining bird in captivity, but are dangerous to introduce into an aviary, on account of their cruelty and boldness.

The natural history of the Swallow is extremely interesting, and has been the cause of much controversy among authors; but we are still in much doubt respecting their manners and habits. A few species visit this country in the summer, and skim over moist and wet places in search of insects, which they dexterously take on the wing. 
GOATSUCKERS. (CAPRIMULGUS.)

THE birds of this family (the last in the Linnæan arrangement) have their moutls of extraordinrry size, opening far beyond the eyes, which enable them to take large insects on the wing. They seldom appear in the day-time, except when disturbed, or in dark cloudy wcather. They lay two eggs, which they deposit on the naked ground. The voice of the European one resembles the noise made by a large spinning wheel.

Among a number of these birds, is that highly curious species The Sierre Leone Goatsuclker. (Caprimulgus Longipennis.) Presented by A. Haworth, Esq. of Chelsea.

BIRDS IN SEPARATE CASES NUMBERED, EACH HAVING A REFERENCE TO THE PAGE IN THIS CATALOGUE, IN WHICH THEY ARE DESCRIBED.

Northern Divers. (Colymbus Glacialis.) Male ànd female. The largest of the Divers measures three feet and a half in length. It is sometimes shot on our coast.

Horned Screamer. (Palamedea Cornuta,) This extraordinary bird is of the size of a large turkey; from the front of the head rises a sharp horn, about four inches long, and each joint of the wings is furnished with an extremely strong, triangular and very sharp spur; those on the shoulder being nearly as large as a man's tinger: they inhabit the fens of South America, and are always found in pairs, feeding on seeds and reptiles. The female makes a nest on the ground, of mud, shaped like an oven, and lays two eggs.

Rarbary Pariridges. (Tetrao Rufus.) Male and female. Beautifully preserved, and placed under a glass shade: presented by Her Majesty.

A pair of beautiful Maccaw's, from the interior of Cayenne, the whole plumage, except the tips of the wings, 
which are green, is of a resplendent deep yellow; they are undescribed by naturalists.

The Great Auk or Northern Penguin. (Alca Impennis.) Of this rare and noble bird, we have no account of any having been killed on the shores of Britain, except this specimen, for upwards of one hundred years. It was taken at Papa Westra in Orkney, to the rocks of which it had resorted for several years, in the summer of 1813, and was finely preserved and sent to me by Miss Trail of that island, a lady to whom I am under considerable obligation for procuring me many valuable and rare subjects from the northern Isles, and much interesting information respecting their habits.

I had the pleasure of examining this curious bird on its native element; it is wholly incapable of flight, but so expert a diver, that every effort to shoot it was ineffectual.

\section{AMPHIBIOUS ANIMALS.}

"Were ev'ry falt'ring tongue of man, Almiahty Father! silent in thy praise, Thy works themselves would raise a general voice Even in the depth of solitary woods, By human foot untrod, proclaim thy power."

MILTON。

\section{TORTOISE。(TESTUDA.)}

Common Tortoise. (Testudo Graca.) This animal is considered as the most common of the European species, and is a native of almost all the countries bordering on the Mediterranean Sea. It lives to a most extraordinary age, instances being adduced of its having considerably exceeded the period of a century.

Geometrical Tortoise. (T. Geometrica.) From its strong and well-contrasted colours, and regularity of pattern, the present species is more readily distinguishable at 
first view than most oihers of this perplexing tribe. The native country of this beautiful tortoise is perhaps not truly known; though the shell is more frequently seen in Europe than that of any other kind.

Close Tortoise. (T. Clausa.) The Close Tortoise obtains its name from the unusual manner in which the under part of the shell is applied to the upper, being continued in such a manner round the margin, that when the animal withdraws its head and legs, it is enabled accurately to close all parts of the shell entirely together, so as to be in a complete state of security; and so strong is the defence (says Shaw, in its Zoology) of this little animal, that it is not only uninjured by having a weight of 5 or 600 lbs. laid upon it, but can walk in its usual manner beneath the load. It is a native of many parts of North America, being chiefly found in marshy places. It is principally sought for on account of its eggs. It feeds on beetles, mice, and even serpents, which it seizes by the middle, and draws into its shell, and thus crushes them to death.

Concentric Tortoise. ( $\boldsymbol{\Gamma}$. Concentrica.) This species is a native of North America, and is sold in the market of Philadelphia and elsewhere, by the name of Terrapin. It is an mhabitant of waters, and is said to be a wholesome and even delicate food. It is also found in Jamaica.

Snap or Snake Tortoise. (T. Serpentina.) This species, first described by Linnæus, appears to have been obscurely known. It is a native of North America, where it inhabits stagnant waters, growing to the weight of 15 or $20 \mathrm{lbs}$. and preying on fish, ducklings, \&c. Whatever it seizes in its mouth, it holds with great force, and will suffer itself to be raised up by a stick rather than quit its hold. This animal conceals itself in muddy waters, in such a manmer as to leave out only part of its back, like a stone or other inanimate object, by which means it the more easily obtains its prey. In New York, it is called the Snapping Tortoise.

It was kept alive in the Museum upwards of eight months, during which time it never tasted food. It 
possessed a most amazing strength, carrying 200lbs. without any apparent inconvenience. Its disposition was exceedingly fierce.

Logger-head Turtle. (T. Caretta.) This turtle exceeds in size every other known species. It inhabits the same seas with the Green Turtle, but is also diffused into very remote latitudes, being often found in the Mediterranean, and about the coasts of Italy and Sicily. In a commercial view, it is of little value; the flesh being coarse and rank, and the plates of the shell being too thin to be of use. It is a strong, fierce, and even dangerous animal.

Several Tortoises, unknown.

The Indian Tortoise. ( $\mathbf{T}$. Indica.) This is the largest known species of the Land Tortoise, the shell being upwards of three feet long, and six feet in circumference. In this specimen the tubercles on the fore part of the shell are wholly wanting.

The Fimbriated Tortoise. (T. Fimbriati.) This is one of the largest species, and most extraordinary in its appearance: it inhabits the rivers of Cayenne and Guiana.

\section{LIZARDS. (LACERTA.)}

THESE Cases contain above 100 species of Lizards ${ }^{\circ}$ beautifully preserved, and displayed on an artiticial rock, so as to exhibit them in their various attitudes, and convey an idea of their haunts and mode of life: the greater part of them being named, we shall only mention those whose history and habits are known and remarkable.

Two specimens of the Flying Dragon. (Draco Volans.) This very extraordinary species of Lizard is a uative of Asia and Africa. "The very name (says Dr. Shaw) comveys to the mass of mankind the idea of some formidable monster, and recals to the imagination the wild fictions of romance and poetry; but the animal distinguished by that title in modern natural history, is a small, harmless Lizard." It is about ten inches long, and furnished with 
large expansible wing-like membranes, which enable it to spring to a considerable distance in quest of its prey; it has a pouch under the throat of a singular appearance, and is altogether different from every other creature.

A young Crocodile. (Lacerta Crocodilus.) This sometimes attains the length of 25 to 30 feet, and is of great swiftness, voracity, and strength, roars lideously, and devours men and other large animals.

A Crocodile from the Island of St. Thomas, differing considerably from the common one.

The Gungetic Crocodile. (L Gangetica.) A very young specimen; grown to the length of 30 feet.

The Alligator. (L. Alligator.) This animal bears so near a resemblance to the Crocodile, that many naturalists have considered it as a mere variety, rather than a distinct species. Catesby says, the largest and greatest number of Alligators inhabit the Torrid Zone. They frequent not only the salt rivers near the sea, but streams of fresh water in the upper parts of the country, where they lie lurking: among the reeds to surprise cattle and other animals. In Jamaica, and many parts of the Continent, they are found about twenty feet in length. They cannot be more terrible in their aspect than they are formidable and mischievous in their nature, sparing neither man nor beast they can surprise, pulling them down under water to drown them, that they may with greater facility and without struggle or resistance devour them. As quadrupeds do not often come in their way, they almost always subsist on fish. This destructive monster can neither swim nor run any other way than straight forward, and is consequently disabled from turning with that agility requisite to catch his prey by pursuit; therefore they do it by surprise, in the water as well as by land. The Alligator is supposed to be a long-lived animal, and its growth is extremely slow.

Dragon Lizard. (L. Draco.) Is a native of South America, and measures two feet four inches in length; it is a harmless animal, and much esteemed as an article of 
food, though to persons unaccustomed to see it, it pres. sents a formidable appearance.

The Iguana. (L. Iguana.) Though the Lizard tribe affords numerous examples of strange and peculiar forms, yet few species are perhaps more eminent in this respect than the Iguana, which grows to a very considerable size, and is often seen the length of from three to five feet. It is a native of many parts of America and the West India Islands, inhabiting rocky and woody places, and feeds on insects and vegetables; is reckoned excellent food, being exceedingly nourishing and delicate; but observed to disagree with some constitutions. The common manner of catching it is by casting a noose over the head, and thus drawing it from its situation; for it seldom makes an effort to escape, but stands looking intently at its discoverer, inflating the throat at the same time in an extraor dinary manner. Iguanas are sometimes salted and bar. reled up for use in Jamaica and other West India islands, in considerable quantities; may easily be tamed while young, and in that state is both an innocent and beautiful creature. The larger one in this Case lived some time in the stove of the Liverpool Botanic Garden, but never was observed to take food; but was easily irritated, at which time it puffed up the pouch under the throat in an extraordinary manner; and on the near approach of dogs, to which it seemed to have an aversion, suddenly struck them forcibly with the tail, but was never known to bite.

Several Chamaleons. (L. Chamzleon.) Few animals have been more celebrated by natural historians than the Chamreleon, which has been sometimes said to possess the power of changing its colour at pleasure, and of assimilating it to that of any particular object or situation. This, however, must be received with great limitations; the change of colours which this animal exhibits varying in degree, according to circumstances of health, temperature of the weather, and many other causes, and consisting chiefly in a sort of alteration of sharles, from the natural greenish or bluish grey of the skin into pale yellowish, with irregular spots of patches of dull red. The Chamaleon is a creature of a harmless nature, and sup 
ports itself by feeding on insects, for which purpose the structure of the tongue is finely adapted, consisting of a long missile body, furnished with a dilated and somewhat tubular tip, by means of which the animal seizes insects with great ease, darting out its tongue in the manner of a Woodpecker, and retracting it instantaneously with the prey secured on the tip. It can also support a long abstinence, and hence arose the idea of its being nourished by air alone. Is found in many parts of the world, and particularly in India and Africa, and also in Spain and Portugal. One that was kept alive in Liverpool was regularly fed with sugar and bread, and appeared to have an affection for the person who had the care of it. Its change of form was as remarkable as that of colour.

A very fine specimen of the American Iguana; presented to the Museum by Lady Cox Hippesley.

The African Iguana.

The Monitor Lizard. (L. Monitor.) The Monitor Lizard is one of the most beautiful of the whole tribe, and is also one of the largest, sometimes measuring not less than four or five feet from the nose to the tip of the tail. This elegant animal is found with little variation in South America, New Holland, and Africa, where it frequents woody and watery places; and if credit may be given to the reports of some authors, is of a disposition as gentle as its appearance is beautiful. It has gained the name of Monitor, from its supposed attachment to the human race, and it has been said that it warns mankind of the approach of the Alligator, by a loud and shrill whistle.

The Galliwasp. (L. Occidua.) The Galliwasp is a native of the American Islands, and seems to be particularly common in Jamaica, where it is said to frequent woudy and marshy districts. The Galliwasp (according to Brown, in his Natural History of Jamaica,) is reckoned the most venomous reptile in that island, and it is said that no creature can recover from its bite: but this he very properly considers merely a popular error. This animal is not noticed by Linnaeus. 


\section{SERPENTS. (SERPENTES.)}

IN these Cases are preserved about 200 different Serpents, finely prepared, and exhibited in their natural positions, with the English and Linnaan names attached to them.

The Great Boa. (Boa Constrictor.) By those who are unacquainted with the wonders of nature, the descriptions given by naturalists of some of the more striking and singular animals are received with a degree of scepticism, or even rejected, as exceeding the bounds of credibility.-Amongst these animals may be numbered the prodigious serpents which are sometimes found in India, Afri$\mathrm{ca}$, and America; serpents of so great a size as to be able to gorge even some of the largest quadrupeds, and of so enormous a length as to measure upwards of thirty feet. There is reason to believe, that these immense serpents are become less common than they were some centuries back: and that in proportion as cultivation and population have increased, the larger species of noxious animals have been expelled from the haunts of mankind. They are, however, occasionally seen, and sometimes approach the plantations nearest to their residence. It is happy for man. kind that these serpents are not poisonous; they are therefore to be dreaded only on account of their size and. strength, which latter is so great as to enable them to kill cattle, deer, and other animals, by writhing themselves round them, so as to crush them to death by mere pres. sure; after which they swallow them in a very gradual manner, and when thus gorged with their prey, grow almost torpid with repletion: and if discovered in this state, may without difficulty be dispatched.-These enormous serpents are natives of Africa, India, the Indian Islands, and South America, where they inhabit marshy and woody places. There are several species of the Boa in this collection, one of which is considered by natural. ists, in respect to beauty of colour, size, or preservation, to be the finest specimen ever brought into this country; it measures thirty-two feet in length, and two feet seves 
inches in circumference, and is preserved in the act of destroying a royal tiger, which is crushed and expiring in the enormous folds of its merciless enemy.

\section{SERPENTS.-No. 2.}

\section{A young specimen of the Boa Constrictor.}

Striped Rattle Snake. (Crotalus Durissus.) Thie Ratthe Snake is the most poisonous of reptiles that inhabit America. The most conspicuous distinction this animal bears from all other of its species, is the rattle, which makes so loud a noise while the creature is in motion, that its apprnach may be known, and danger avoided. Many naturalists are of opinion, that this snake acquires an additional bone to the rattle every year; from the number of which bones, the precise age of the suake may be known. Catesby, in his History of Carolina, says, "the Rattle Snake is the most inactive and sluggish of animals, and is never the aggressor, except upon what he preys; for unless disturbed he never bites, and when provoked gives warning by shaking his rattles, so that a person has time to escape." It is said that this snake has the power of charming or fascinating small animals within reach, which it devours. Squirrels and birds are its principal prey, and no sooner do they spy the snake than they skip from bough to bough, and approach by degrees nearer to the enemy, regardless of any danger, until they enter the extended jaws that are open to seal their ruin. Bartram observes, that some Indian nations never kill the Rattle Suake, or any other species, alleging as their motive, that it would influence its living kindred to revenge the injury or violence done to it when alive. The flesh of the Rattle Snake is said to be much relished, even by Europeans.

Spectacle Snake, or Cobra de Capello. (Coluber Naja.) The Coluber Naja, or Cobra de Capelio, is a native of India, where it appears to be one of the most common, as well as the most noxious of the serpent tribe; very 
frequently proving fatal in the space of a few minutes to those who unfortunately experience its bite. In India it is exhibited as a show, and is of course more universally known in that country than almost any other of the race of reptiles. It is carried about in a covered basket, and managed by the proprietors in such a manner, as to assume a dancing motion at the sound of a musical instrument. The Indian jugglers, who thus exhibit the animal, deprive it of its fangs, by which they are secured from its bite.

A poisonous Serpent from Senegal, of considerable dimensions, which is bitherto undescribed.

The Striped Rattle Sncke. The appearance of this reptile is as disgusting and terrific, as its qualities are destructive: it is of very large size, and is remarkable for the flat shape of the head.

The Crimson-sided Snake. (Coluber Porphyriacus.) Is remarkable for the beauty of its colours: it is about four feet in length; and its sides are marked with alter nate lines of crimson and yellow.

\section{THE ROYAL TIGER. (F. TIGRINA.)}

This animal is represented expiring in one of those dreadful combats which sometimes take place betwixt this powerful and sanguinary destroyer of the human species, and the immense serpent of India, called the Boa Constrictor, in whose enormous folds its unavailing strength is nearly exhausted, and its bones crushed and broken by the strength and weight of its tremendous adversary. 


\section{6 \\ F IS H E S.}

See through the air, the ocean, and this eartl, All matter quick, and bursting into birth; Above how high progressive life may go, Around how wide, how deep extend below! Vast chain of being, which from Gov began, Nature's ethereal, human, angel, man, Beast, bird, fish, insect, what no eye can see, No glass can reach; from infinite to Thee, From Thee to nothing!

Coryphene, or Dolphin. (Coryphona Hippuris.) The Dolphin is an inhabitant of the Mediterranean, Indian, and Atlantic seas, where it often appears in large shoals, and is sometimes observed to follow ships, devouring with avidity any occasional article of food which may happen to be thrown overboard; it will also swallow substances of a different nature; and we are informed, from the authority of Plumier, that in the stomach of one which was examined, were found four iron nails, one of which measured more than tive inches. When taken out of the water, the beautiful colours (with which the fish is decorated when living) fade as it expires; the lustre vanishing by degrees, till at length it becomes of a dull grey colour. This gradual evanescence of colour in the dying Coryphene is contemplated by sailors with as much delight as the Romans are said to have exhibited on viewing similar changes in the expiring Mullet, when brought to their tables before the feast began. The Coryphene is a strong and vigorous fish, and swims with great rapidity. It is perpetually engaged in the pursuit of smaller fishes, and is considered as one of the most cruel persecutors of the Flying Fish. The flesh is said to be excellent.

Flying Gurnard. (Trigla Volitans.) This highly singular and beautiful species is a native of the Mediterranean, Atlantic, and Indian seas, where it swims in shoals, and is often seen flying out of the water, in the save manner as the Flying Fish, Exocctus. In its native ele- 
ment, the colours of this fish are extremely brilliant. It is crimson above; pale, or of a white colour underneath. The pectoral fins are extremely large, transparent, of an olive green, richly varied with numerous bright blue spots. The tail is pale violet, with the rays crossed by dusky spots, and strengthened on each side the base by two obliquely transverse bony ribs or bars.

Small Saw Fish. (Pristis Antiquorum.) The Saw Tish is a species of Shark, growing to the length of tifteen feet or more; is an iuhabitant of the Mediferranean and Northern seas, and was known to the ancient writers by the name of Pristis.

Striped Chcelodon. (Chxtodon Striatus.) This fish is a native of the Indian and American seas.

Unknown. (Sparrus.)

Porcupine Fish. (Diodon Hystrix.) In point of liabit or external appearance, the remarkable genus Diodon may be said to connect in some degree the tribe of fishes with that of the spiny quadrupeds, such as the porcupines and hedge-hogs; it is also allied in a similar manner to the Echini, or Sea Urchins. The Diodon Hystrix, commonly termed the Sea Porcupine, is said to afford an amusing sight when taken by a line and hook, baited by a species of crab : after seizing the bait, by a sudden spring, on funding itself hooked, it exhibits every appearance of violent rage, inflating its body, and elevating its spines to the highest possible degree, as if endeavouring to wound in all directions: till after having tired itself by its vain efforts, it suddenly expels the air from its body, and becomes flaccid for some time: but when drawn towards the shore, redoubles its rage, and again inflates its body: in this state it is left on the sand, it being impossible to touch it without danger till it is dead. It is a native of the Indian and American seas, and is considered as a coarse fish, but is'sometimes eaten by the inhabitants of the West Indian Islands.

\section{Unknown. (Lophiss.)}

Torpedo Ray. (Raja Torpedo.) The Torpedo has been celebrated, woth by ancients and moderns, for its wonderful faculty of causing a numbness or painful sensa- 
tion in the limbs of those who touch or handle it. The shock or sensation given by this Ray, is attended with all the effects of that produced by the electrical machine, so far as experiment hitherto has enabled us to discover. Although this fish does not appear to be furnished with any striking exterior qualities; although it has no muscles formed for great exertions; nor any internal conformation differing from the Ray kind; yet such are the wonderful powers it possesses, that in an instant it can paralyse the hand or body that touches it, and cause for a while a total suspension of the mental faculties. Reaumer has by several experiments attempted to demonstrate, that it is not necessarily, but by a voluntary effort, that the 'Torpedo benumbs the hand that tonches it. On every trial he could readily perceive when it intended to give the stroke, and when it was about to continue inoffensive. In preparing to give the shock, it flattened its back, raised its head and tail, and then by a violent contraction in the opposice direction, struck with its back against the finger that touched it; and its body, which before was flat, became round and lumped. IE is said, that the Negroes can handle the Torpedo without being affected; and we are told the whole secret of securing themselves from its bite consists in keeping respiration suspended at the time. The elecIrical power, however, is hnown to terminate with the life of the animal, and when dead it is handled or eaten with perfect safety. It is an inhabitant of the Northern, European, and the Mediterranean seas.

Sea Horse. (Syngnathus Hippocampus.) The Hippocanopus is a fish of a highly singular appearance. In its dry or contracted state, this animial exhibits the fancied resemblance from which it takes its name; but in the living fish, this appearance is somewhat less striking, the head and tail being carried nearly straight. It is a native of the Mediterranean, Northern, and Atlantic seas. A finer specimen of this species of Pipe-tish is in another place under a glass; and one of a more curious form, the Foliated Pipe-fish.

Long-finned Chatodon. (Chatodon Teira.) This curious fish is a native of the Indian and Arabian seas, and is said to arrive at a considerable size. 
Harlequin Angler. (Lophius Histrio.) This species is a native of the Indian and American seas, growing to the length of ten or twelve inches, and in manners resembles the European Angler. Monsieur Renard, in his history of Fishes, affirms, that he knew an instance of an individual of this species kept for three days out of water, and which walked about the house in the manner of 2 dog.

Young Frog-fish, or Angler. (L. Europaus.) The Frog-fish is remarkable for its uncouth appearance. The one under consideration is an inhabitant of the European seas, where it sometimes arrives at a great size. It is observed to frequent shallow parts of the sea, lying in am. bush, covered with weeds and mud, in such a manner that the smaller fishes, deceived by its tentacula, or long processes on the head, by their resenblance to worms, on attempting to seize them become a prey to the Lophius.

Beaked, Angler, or Bnt-jesh. (L. Rostratus.) A native of South America; it preys upon small hishes and worms.

Remora, or Sucking-fish. (Echeneis Remora.) This fish has the power of adhering to whatever it comes in contact with, in the same manner as a cupping glass adheres to the human body. It is by such an apparatus that this tish sticks to the body of a shark, drains away its moisture, and produces a gradual decay. It is found principally in the Mediterranean and Atlantic seas, where it grows to the length of about eighteen inches.

The Bony-scaled Pilke. (Esox Osseus.) This is a fish of considerable size, and of very remarkable appearance, being covered with strong bony scales, disposed in long oblique rows, which give it the appearance of being carved out of a solid piece of ivory. It is a native of the fresh-water lakes and rivers of America, and the Alesh is said to be excellent.

\section{Lump Sucker. (Cyclopterus Lumpus.)}

Pavonian Sucker. (C. Pavonius.) This beautiful fish was caught in the river Mersey, near Liverpool. 
Armed Loricaria. (Loricaria Catafracta.) Found in the American seas.

\section{Yellow Loricaria. (L. Flava.)}

Slender Fistularia, or Trumpet-fish. (Fistularia Tabacaria.) This very remarkable fish is a native of the American seas, and subsists on the smaller fishes, sea-insects, and worms.

Oceanic Flying-fish. (Exocætus Evolans.) The fishes of this genus, which are few in number, are remarkable for the extremelength and size of their pectoral fins, by which they are enabled to spring from the water, and support a kind of temporary flight or continued motion through the air to the distance of 2 or 300 feet; when the fins become dry, they are obliged to commit themselves to their own element. The fish here described is an inhabitant of the American and Indian seas, and is occasionally observed in the Mediterranean. Pennant records an instance of its being seen about the British coasts. The celebrated Bonnet considered this species of fish as forming a kind of connecting link between fishes and birds, similar to that which bats may be supposed to form between birds and quadrupeds.

Lasker Bulhead. (Cottus Scorpius.) This fish is an imhabitant of the Mediterranean and Northern seas; is said to be plentiful about the coast of Greenland, where it is esteemed good food. It is a strong fish, swimming with rapidity, and preying on smaller fishes; and is said to live a considerable time out of the water, having a power of closing the gill covers in such a manner as to exclude the effect of the atmospheric air. When caught, if held in the hand, it emits a strong and peculiar sound by the expulsion of air through its mouth; during this action the mouth is opened to the utmost width, the pectoral fins are strongly expanded, and the whole body is agitated by a vibrating or tremulous motion.

Hare-mouth Globe-fish. (Tetrodon Lagocephalus.) This genus, like the Diodon, has the power of inflating its body at pleasure. Is an inhabitant of the Indian and American seas, but occasionally strays into the northern 
latitudes, and has been taken, according to Pennant, about the British coasts, near Penzance in Cornwall.

\section{Round Diodon, Sea Hedge-hog. (Diodon Orbi-} cularis.)

Lamprey. (Petromyzon Marinus.) This fish has long held its place at the tables of the luxurious, having always formed a part of the splendid feasts of our ancient nobility. King Henry I. lost his life by too great an indulgence of this his favourite dish. In the early part of the year they are met with in great numbers in the river Severn, when they are potted in large quantities, and sent to London.

The Hammer-headed Shark. (Squalis Zygzena.) This is a very voracious and deformed animal, and differs from any other known creature; they sometimes attain the length of 15 feet, and are natives of the Mediterranean and Indian seas.

\section{Argel Fish, or Shark. (S. Squatina.)}

Jacksonian Shark. (S. Jacksonii.) This is a new species, lately discovered in the harbour of Port Jackson.

Young Shark. (\$. Carcharias.) The Shark is as formidable in appearance as he is dreadful for his courage and activity. No fish can swim so fast, for he will outstrip the swiftest ship. "They are (says Mr. Pennant) the dread of sailors in all hot countries, where they constantly attend the vessels in expectation of what may drop overboard: a man that has that misfortune perishes without redemption; they have been seen to dart at him, like gudgeons at a worm." They are said to attack Negroes in preference to Europeans, and to attend with assiduity the slave ships from Africa to the West. Indies. The Shark grows to an enormous size, sometimes 30 feet in length.

\section{Horned Trunk-Fish. (Ostracion Cornutus.)}

Young Sturgeon. (Accipenser Sturio.) Inhabits the European, Mediterranean, Red, Black, and Caspian seas, and annually descends the rivers in spring. It is a fish of 
slow movement, and is very prolific. Its flesh is held in great estimation.

Frog-Fish. (Lophius Europrus.) Taken in the river Mersey.

\section{INSECTS. (INSECTA.)}

Each moss,

Each shell, each crawling insect, holds a rank;

Important in the plan cf Him who form'd

This scale of beings; holds a rank, which lost

Would break the chain, and leave a gap

"That Nature's self would rue!

IN this Case is a brilliant display of the Insect tribe, consisting of a selection of about 500 of those most remarkable for their beauty of colours, extraordinary form, or singularity of manner or economy. A bare recitation of the names of this very numerous class would add but little to the information or pleasure of the general reader, and would increase the size and expense of this Catalogue unnecessarily: we shall therefore give only those best known or most remarkable.

Hercules Beetle. (Scarabæus Hercules.) The Beetle here described is a native of the island of Guadaloupe; on the continent of New Spain this species is said to be often seen of very large dimensions. The horn is toothed above on each side, and beneath it is covered with a substance resembling yellow plush; the proboscis below is also toothed. Between these, it is said, the insect takes the smaller branches of trees, and by swiftly flying round soon saws them off, for the purpose of building its nest. The teeth cut away the wood, and the plush part serves to brush away the saw-dust. Dr. Shaw, however, in his Naturalist's Miscellany, says, that on a narrow 
inspection of the proboscis of this Beetle, it will appear no ways calculated for the sawing off branches from the trees; he reckons therefore 1 he whole operation as a vulgar error. It is a very mischievous animal, and exceedingly difficult to be taken. It measures seven inches. in length.

Actron Beetle. (S. Actron.) This is the largest of insects, except the Crabs and Monoculi. It is a native of South America.

Stag Beetle. (Lucanus Cervus.) This is found in England in decayed trees.

\section{Patch-winged Diamond Beelle. (Curculio Splendens.)}

Dirmond Beetle. (Curculio Imperialis.) There are several species of these, which, with the above, are natives of South America; and perhaps the whole insect race does not display more splendour or riclness; it may be truly said, that "Solomon in all his glory was not arrayed like one of these."

Gevambyx Giganteas. The body of this extraordinary insect is mearly six inches long. It is a native of Cayenne, and very rare.

\section{The Giant Mantis. (Mantis Gigas.)}

Praying Mantis. (M. Oratoria.) Most of the genus Mantis, and this species in particular, are held sacred by the natives of the country they inhabit. From the singular manner in which it raises the upper part of the body and fore legs, it is supposed to point out the way to travellers that have lost their road. Many of the Mantis so strongly resemble leaves, that at first they can scarcely be known.

Great Locust. (Gryllus Giganteus.)

African Locust. (G. Capensis.)

Elephant Eocust. (G. Elephas.) Of all insects which are capable of adding to the calamities of mankind, by devouring the products of the earth, Locusts seem to possess the most formidable powers of destruction, Le. 
grions of those voracious creatures are from time to time produced in the various parts of Africa, and the eastern world, where the havoc they commit is almost incredible, changing in a few hours the most fertile plains into an appearance of a desart; nay, even when dead they are terrible, since the putrefaction which arises from their inconceivable numbers, is such, that it has been regarded as one of the principal causes of a pestilence. The largest species of these insects are used as an article of food, and in many markets of the Levant they are publicly sold. The female is regarded as a very nutritious sustenance, and is much sought after.

Great Lantern Fly. (Fulgora Lanternaria.) This highly curious insect is a native of South America; from the large, hollow, transparent projection in front of the head it emits a sufficient light for persons to read by; and travellers are said to be directed on their journey by night, by fixing one or two of them on a stick.

Common Cicada. (Cicada Plebia.) The Cicada, so often commemorated by the ancient poets, and so generally confounded by the major part of translators with the Grasshopper, is a native of the warmer parts of Europe, and is particularly plentiful in Italy and Greece. The common Cicada appears in the hottest summer months, and continues its shrill chirping during the greatest part of the day, sitting amongst the leaves of trees.

Atlas Moth. (Phalæna Atlas.) This is by much the largest of Moths, measuring nine inches across the wings: it is a native of the East Indies and South America.

Great Black Wasp of Pennsylvania. This Wasp supplies itself with food by roving about the meadows, catching grasshoppers and other insects; on these it feeds, and not on fruits, as other Wasps do: but what is more remarkable, is the method of making their nests, and providing for their young. With great pains and industry they scratch an horizontal hole, near an inch diameter and a foot long, in the steep side of a bank of loamy earth; then away the Wasp flies, and catches a large grasshopper, and lodging it in the further end of 
the nest, there she lays an egg, and then goes and catches two more, and deposits them with the other, then plas. ters up the hole. The egg soon produces a maggot; these grasshoppers are, by marvellous instinct, provided for its food, until it changes into its pupa state, in which it lies for a certain period, and then eats its way out, and flies away, seeking its mate. What may deserve our further attention is, the wonderful sagacity of this creature, not only in catching these large grasshoppers, though bigger than itself, which are like ours, and are very strong and nimble, but their peculiar skill is to be admired in disabling them, either by bite or sting, so as not to kill them; for then they would soon putrefy, and be unfit for nourishment. Life sufficient is left to preserve them for the time the maggot is to feed upon them. The sting of this Wasp is painful, but does not swell like others.

The Female, or Queen of the Termites, or White Ant. (Termes Fatale.) Mr. Smeathman, who resided many years in Africa, has, in the 71 st volume of the Philosophical Transactions, given a beautiful and interesting account of the manners, instinct, and wonderful economy of these extraordinary animals, which, from their immense number and power of annoyance, are the greatest pest of that country.-.'To detail the whole of their habits and mode of life would require a volume; the instinct of the Common Ant, the Bee, or the Beaver, are trifling when compared with these. Though little larger than the Common Ant, their buildings, from the number, closeness, and magnitude, often appear like the villages of the natives; and the depredations they commit render them truly formidable: norhing but metal or glass can escape the destroying fangs of these minute invaders. The one in this collection is a pregnant queen, the general mother of the whole community, and is a thousand times heavier than the male, or king, who is considerably larger than the labourer or soldier.-Mr. Smeathman's description of this Ant has been copied in Dr. Winterbotham's Account of Sierra Leone, and the second volume of Wood's Zoography, page 446. A model of 


\section{6}

the nest of these remarkable insects, nine feet high, is in the Pantherion.

The Bird-catching, or Great Surinam Spider. (Arrdnea Avecularia.) The insect above mentioned is the largest of all the Spiders, measuring from eight to ten inches in the extent of its legs, which are covered with rough hair: it is not uncommon in many parts of South America. It resides amongst the trees, and seizes on small kirds, particularly humming birds, which it-destroys by sucking their blood, after having first wounded them by its fangs. This Spider has eight eyes, which are disposed somewhat in the form of an oblong square; two are perfectly round, the others are of an oval shape.

Tarantula Spider. (A. Tarantula.) With its curious nest. This is the animal of which such long accounts have been given of the wonderful and melancholy effects arising from its bite, which is represented to be cured only by music, which caused the patient involuntarily to dance in the most violent manner: but the whole account being clearly proved to have existed in vulgar error, is not now worth repeating. The nest is highly curious from its remarkable structure; it is cylindric, with a valve or door, which the animal opens and shuts every time it enters; the manner in which this is performed, as well as the creature itself, is described by the elegant pen of Darwin, in his Zoonomia.

African Scorpion. (Scorpio Afer.) There are several species of scorpions in this collection, but none of them so remarkable, either for size or malignity of poison, as the above, which is near nine inches long, and armed in front by strong claws, resembling those of some species of crab); but its poisonous sting is situated at the end of the tail, in which may be observed the reservoir for supplying it with the fatal fluid, and the minute holes on each side of the sting, through which it is injected into the wound.

Great Centipede. (Scolopendra Morsitans.) This is likewise a native of the hottest parts of the world, and one of the pests of society, being highly poisonous; but 
what renders it particularly dangerous is, its frequenting inhabited places, and biting persons during their sleep, to prevent which, they are obliged to place the feet of their bedstearls in water; it measures twelve inches in length.

\section{SHELLS. (ConChOLOGY.)}

THIS department consists of an extensive collection of beantiful and rare shells from every part of the known world; they principally occupy the centre of the Great hoom, and are arranged in their respective families, according to the Linnæan classification, in Cases, and under large Glass Shades, upon appropriate bronzed stands, and make with the Fishes, Crabs, Asterias Echini, Madrepores, Gorgonias, Isis, Sponges, and other Marine productions, a most interesting display of the inhabitants of the waters. About one thousand four hundred have their generic names attached to the Cases, and the most remarkable have their specific also; to enumerate the whole of which would far exceed the limits of a work of this description. The History of the Paper Nautilus (Argonauto Argo) is, however, so remarkable, that it cannot be omitted. Pope in his Essay on Man alludes to it, where he says-

"Learn of the little Nantilus to sail;

Spread the thin oar, and catch the driving gale."

Pliny describes it thus: "But amongst the prircipal miracles of nature is the animal called Pompilos or Nautilus: it ascends to the surface of the sea in a supine posture, and gradually raising itself up, forces, by means of its tube, all the water from the shell, in order that it may swim the more readily; then throwing back the two foremost arms, displays between them a membrane of wonderful tenuity, which acts as a sail, while with the remaining arms it rows itself along, the tail in the middle acting as an helm to directs its course; and thus pursues its voyage like a little ship, fill alarmed by any appear. ance of danger, when it takes in the water, and de. scends." 
Several specimens of the Argonauta and Nautilus genera are in the same Case with the Cone Shells; among the latter of which are very fine specimens of the Lord High Admiral, the Gold Brocade, the Cobweb, and other esteemed shells of this genus.

Among the shells, denominated Multivalves, are specimens of those which perforate the bottoms of ships; they appear to have bedded themselves in the wood, and thus show the necessity for coppering vessels that perform long voyages.

In the Murex genus is a beautiful specimen of the Thorny Woodcock; the long spines of which are as acute as the points of needles.

The small Bell Glass, No. 4, contains several articles which were once the property of the celebrated Sir Charles Linnæus; a specimen of whose writing is likewise inclosed. Presented by Dr. Smith, President of the Linnaean Society.

Among the Turbos is the finest specimen of that rare shell the Wentletrap (Turbo Scalaris) ever known; it was brought from Amboyna by the late Mr. Webber, of Blackheath, who once refused the sum of $500 l$. oftered for it by the late Earl of Bute.

\section{ZOOPHYTES.}

CORALS, MADREPORES, \&c.

Gradual, from these what numerous kinds descend Evading e'en the microscopic eye!

Full Nature swarms with life; one wondrous mass Of animals, or atoms organized,

Waiting the vital breath, when Parent Heaven

Shall bid his spirit blow.

THOMSON.

THE various Cases contain a rich and numerous assem. blage of the inhabitants of the marine world, disposed in such a manner as they may be supposed to exist in the 
bottom of their native element: they consist of Corals, Corallines, Madrepores, Gorgonias, Sponges, \&c. \&c. to describe which accurately would require the pen of an Ellis or a Solander, and would far exceed the limits of this little publication. We shall merely observe, that till lately the principal parts of the contents of these Cases were considered as marine vegetables, growing from the bottom of the ocean; but the observation of later naturalists have decidedly proved them to be the fabrication of different minute animals, which however insignificant they may appear to the unobserving part of mankind, are, from their immense, their inconceivable numbers, of more consequence than generally supposed; it is to the accumulated myriads of them that we owe part of the island on which we live; our hills are in many places full of them, and some rocks are entirely of their formation. New islands have been formed within the memory of persons now living: and many seas are becoming every year more difficult to navigate, being nearly choaked up by the habitations of animals almost too small for human perception.

"The whole group of the Thousand Islands, and indeed the greater part of those whose surfaces are flat, in the neighbourhood of the equator, owe their origin to the labours of that order of marine worms which Linnæus has arranged under the name of Zoophyta. These little animals, in a most surprising manner, construct the calcareous habitations under an infinite number of forms; yet with that order and regularity, each after its own manner, which, to the minute inquirer, is so discernible in every part of the creation. But, although the eye may be convinced of the fact, it is difficult for the human mind to conceive the possibility of insects so small being indued with power, much less of being furnished in their own bodies with the materials for constructing the im. mense fabrics, which, in almost every part of the Eastern and Pacific Oceans, lying between the tropics, are met with in the shape of detached rocks or reefs, of great extent, just even with the surface; or islands already clothed with plants, whose bases are fixed at the bottom of the sea, several hundred feet deep, where light and 
heat, so very essential to animal life, if not excluded, are sparingly received and feebly felt. Thousands of such rocks, reefs, and islands are known to exist in the Eastern Ocean, within, and even beyond the limits of the tropics. The eastern coast of New Holland is almost wholly girt with reefs and islands of coral rock, rising perpendicularly from the bottom of the abyss. Captain Kent of the Buffalo, speaking of a coral reef of many miles in extent, on the south-west coast of $\mathrm{New}$ Caledonia, observes, that ' it is level with the water's edge, and towards the sea as steep as the wall of a house; that he sounded frequently within twice the ship's length of it, with a line of one hundred and fifty fathoms, or nine hundred feet, without being able to reach the bottom." How wonderful-how inconceivable! that such stupendous fabrics should rise into existence from the silent but incessant and almost imperceptible labours of such insignificant worms!"

To the Museum has just been added, the fine collection of Fossil-shells, and other Antediluvian remains collected by the late Mr. Knight, of Blandford: they are principally of this country, and those from Hordwell Cliff extremely perfect and interesting.

A very large Bell Glass, containing about 120 species of Crabs and other Marine Animals, disposed in an appropriate manner on Corals, \&c.

\section{MINERALS.}

Beautiful Group of Crystals, of extraordinary size, from the mines of Dauphiny; presented by Thoma Allan, Esq. of Edinburgh.

Pipe Chalcedony, from Iceland.

A large specimen of Opal in the matrix.

Three Opals, polished. 
Native Gold on Quarts, from Transylvania.

Native Gold, from the Wicklow mountain in Ireland,

Oriental Cut's Eye.

Aqua Marine or B'eryl, polished.

Fluor Spar, from Derbyshire.

Group af Amethist Crystals, from Hungary。

Sulphurets of Arsenic.

Beautiful Pearl Spar, with snow-like appearance, from Transylvania.

Pearl Spar, crystallized, from Hungary.

Fine specimen of Crystallized Iron Ore, with an iridescent surface, from the Isle of Elbe, on the coast of Tuscany.

Splendid Iron Ore, from Hungary.

Bubbled Malachites, Carbonate of Copper, with Mountain Blue, from Siberia.

Native Copper, from Cornwall.

Copper Ore, from ditto.

Model of the Pigot Diamond, valued at 35,000

Variety of Crystals, from Buenos Ayres; containing silver-like appearances, and other extraneous matter.

\section{MISCELLANEOUS ARTICLES.}

NUMEROUS, extraordinary, and stupendous remains of nondescript animals, found in the vicinity of the rivers Ohio, Wabash, Illinois, Mississippi, Osage, Missouri, \&c. brought to England by a gentleman who passed several years on a mineralogical tour in the untrequented parts of North America. They consist of different parts of animals, such as heads, vertebra, ribs, grinders, and horns: 
among which, the most worthy of remark, is the foot of a clawed animal of the fere order, or tiger species. This paw, clothed with flesh, skin, and hair, filled with muscles, flexors, and cartilages, when dilated on its prey, must have covered a space of ground four feet by three. Did the animal to whom it appertained partake of a strength of body proportionate to the size of this foot, and at the same time add the agility and ferocity of the tiger to his unequalled magnitude, he must have been the terror of the forest, and of mankind. That such an animal did exist, this specimen is a sufficient proof; nor did it alone inhabit America, for we have reason to believe that an animal, similar in some respects to the above, once lad possession of our island; for various remains of nondescript animals have been frequently dug up of late in different counties. The thigh-bone, marked A. which is nearly four feet in length, was found in making the Ellesmere Canal, in the year 1803, near the village of Wrenbury, in Cheshire. B. is one toe of the clawed foot. C. several joints of the tail, which must in the living animal have been as thick as an ordinary oak tree. $D$. one of the vertebræ of the back; the passage for the spinal marrow is so large, that a man's arm may with ease pass through it. E. is a section of a spiral tusk, thirteen feet in length. F. a carnivorous grinder, nine pounds weight, being one hundred and forty-four times as heavy as that of a horse. G. a large grinder of another species of these stupendous nondescripts, evidently an herbivorous animal. On the subject however of these Incognitia, but a few words are necessary : they have been, on the whole, the surprise of the enlightened naturalist, and the admiration of the classical scholar; we therefore refer those, who wish to be more particularly informed respecting these remains, to a pamplslet, entitled, "Memoirs of Mammoth, and other extraordinary and stupendous Bones," written by the gentleman who brought them to England, and sold them to the Proprietor of this Museum. It may be had at the rooms, price $1 s .6 d$.

A Glass Cover near the bones, contains a very interesting article to the Naturalist, as it tends to throw some light on an obscurity which envelops these objects. It is 
a portion of the different kinds of hair of a species of Mammoth recently found entire, and brought to St. Petersburgh by Mr. Michael Adams, who has published a particular account of it, of which the following is an extract. "In the summer of the year 1799, during their annual excursions, a chief of the Tongouses discovered on the shore of the frozen sea, near the mouth of the river Lenna, an entire Mammoth, enclosed in a rock of ice, which rendered it impossible to be got at till about five years afterwards, when during a warm summer, the ice became so much dissolved, that the hinge carcase fell out, and slid down about a hundred paces from its bed; when the Tongouses cut off the ivory tusks (the only part considered of value by them) and left it a prey to the white Bears, Gluttons, Wolves, and Foxes. It was near two years afterwards, that, by a fortunate circumstance, $M r$. Adams heard of it, went immediately to the spot, and rescued the complete skeleton and part of the skin, which he transported by land to St. Petersburgh, (a distance of 7500 miles) where it is now set up in the Imperial Aca. demy. A rude drawing made of it when prefect, represents it as having an appearance somethirg between a Pig and an Elephant, having pointed ears and a long brisly mane, along the whole back; it was about 15 feet in length, and 10 high, the bones of the head (without the tusks) weighed 4.601 bs. Upon the whole, there can be little doubt but it was the species of Northern Elephant now extinct, the bones of which are found both in America and Europe; large quantities having been lately discovered in several parts of England."

Sir Joseph Banks received a piece of skin and portions of hair, similar to what is in this collection, as a present from Mr. Adams, which is now in the Royal College of Surgeons, Lincolns-Inn Fields.

Glass Case, containing an Egyptian Mummy.

The ancient methods observed by the Egyptians in embalming human bodies, according to Herodotus; were performed after this manner: "There were certain persons appointed for the business, who had three prices according to the workmanship. In the most esteemed 
method of embalming, they extracted the brains by the nose with a crooked iron, and then poured in drugs: afterwards, they opened the body, took out the bowels, washed the inside with palm wine, and having rubbed into it pounded perfumes, filled the cavity with myrrh, cassia, and other spices, and then sewed it up. After this they washed the body with nitre, and let it lie seventy days; and having washed it again, bound it up in folds of linen, besmearing it over with gums, which the Egyptians used instead of glue. The relations then took lome the body, and enclosing it in the wooden figure of a man, placed it in the catacombs. Another method of embalming, was injecting turpentine of cedar with a pipe into the body without cutting it; they then salted it for seventy days, and afterwards drew out the pipe, which brought along with it the intestines. The nitre dried up the flesh, leaving nothing but skin and bones. The third way was only by cleansing the inside with salt and water, and salting it for seventy days." From what Diodorus observes, one would imagine that there was a way of preserving the bodies much superior to either of the former; for he says, their eye-brows and eye-lashes, with the form and appearance of the whole body, were so well preserved, that they might be known by their features; whence many of the Egyptians kept the bodies of their ancestors in houses adorned at a great expense; and had the pleasure to see their forefathers for many generations back, and to observe all their features as well as if they were living. It does not, however, appear that any bodies were ever discovered embalmed in this manner.

The Mummy in this collection was brought from Egypt by the French, and taken from them by an English privateer, and was remarkable for containing only the head, and part of the thigh and leg bones, which were enveloped in folds of fine linen, nearly three inches thick. The linen in some parts was as white and perfect as when first done, and on the legs there was some of the flesh still remaining, although, from a moderate calculation, it must have been embalmed upwards of two thousand years.

A Mummy of the White Ibis. The white Ibis, though now unknown to the Egyptians, was formerly worshipped 
by them as a deity, in consequence of the great service which it did them in destroying the vast quantities of serpents and reptiles with which that country was infested. The veneration for them extended even after their death ; for whenever the body of a dead Ibis could be found, it was carefully embalmed, after the manner of the mummies, Mr. Bruce, the Abyssinian traveller, mentions his having opened several of them, in which the bones, and even some feathers, were entire. Buffon says, " he received several of these mummies from the bird pits, in the plains of Saccara; that the shape of all of them was a sort of doll, formed by the bandages which incased the bird, of which the greater part fell into black dust when the ligatures were removed." They are generally preserved in earthern jars, with the cover cemented down; but sometimes, as is the case in this, put into a kind of coffin made of sycamore, the covers of which were decorated with hieroglyphics, which are yet visible in the one in this Museum.

\section{A Mummy of the Ibis, opened to show its contents.}

Hasselquist, and other naturalists and travellers who have visited the catacombs of Egypt, say that the mummies of the Ibis contain in general little but black dust, which is believed to be the remains of the bird; but that they were informed that sometimes, though very rarely, the bones and feathers were found in them: this is the case with the one in this Museum; the cloth in which it was wrapped, the bill, bones, and feathers, are still entire. This very interesting and curious article was added to this collection by the liberality of Jacob Wilkinson, Esq. of Bath, whose brother, C. Wilkinson, Esq. of Clapham, brought it from Egypt. What are our boasted monuments of antiquity? the dates of our churches and cathedrals (though crumbled and crumbling inio dust) are but as yesterday when compared with the age of a few perishable feathers, which had existence on the banks of the Nile perhaps two thousand years before the foundation stone of the first of them was laid. What a field for reflection does the contemplation of this article open to our view! 
"Son of to-day thy daring hopes are vain, That aught of thee my lerigthened date shall gain."

A Mummy of the Ibis, in its orignal envelope, as taken from the earthen vessel, the linen cloth, for the manufacture of which the ancient Egyptians were celebrated, remaining entire. Presented by the Bishop of Durham.

Elephant's Head and Grinders; presented by Samuel Staniforth, Esq. Liverpool.

Three Noses of the Saw Fish. The largest of these is three feet seven inches long, eight inches broad at the base, and four at the point; it is armed at the sides with thirty-eight strong teeth, about an inch and a half long, and two inches from each other.

The Jaws of an enormous Shark, which measure six feet six inches in circumference.

The Fossil Tooth of a Shark, nearly four times as large as those in the above jaws.

The Horn of the Narwhale, or Sea Unicorn, nine feet six inches long, of the most beautiful ivory, tinely wreathed.

The Jaws of a Porpoise.

Skull of the Walrus.

Glass Case, containing four different Beaks and Heads of the Calao, or Hornbill Bird; remarkable for the singular appendages on the upper mandibles. No. 1. Helmet Hornbill. No. 2. Pied Hornbill. No. 3. Rhinoceros Hornbill. No. 4. Philippa Hornbill.

Fossil of a Turtle; the only one known.

Fossil of the Head of an Aninal, resembling a Crocodile of enormous size. This wonderful object was found in Dorsetshire.

Fossil of a Stag's Head and Horns of enormous size' found in Ireland. 


\section{A \\ COMPANION}

\section{TO TEE \\ PANTHERION.}

NATURAL HISTORY.

\section{QUADRUPEDS.}

These are thy glorious works, Parent of Good!

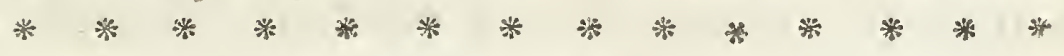
Thou sitt'st above those heavens

To us invisible, or dimly seen

In these thy lowest works; yet these declare Thy goodness beyond thought, and power divine.

MELTOP.

The PanTherion is an exhibition of Natural History, on a plan entirely novel, intended to display the whole of the known Quadrupeds, in a manner that will convey a more perfect idea of their haunts and mode of life than has hitherto been done, keeping them at the same time in their classic arrange. ment, and preserving them from the injury of dust and air : it occupies an extensive apartment, nearly 
forty feet high, erected for the purpose. The visitor is introduced through a basaltic cavern (of the same kind as the Giant's Causeway, or Fingall's Cave, in the Isle of Staffa) into an Indian hut, situated in a Tropical Forest, in which are displayed most of the Quadrupeds described by naturalists, with correct models from nature, or the best authorities, of the trees and other vegetable productions of the torrid climes, remarkable for the richness or beauty of their fruit, or the singularity of their foliage; the whole assisted by an appropriate panoramic effect of distance, which makes the illusion produced so strong, that the surprised visitor finds himself suddenly transported from a crowded metropolis to the depth of an Indian forest, every part of which is occupied by its various savage inhabitants.

The Linnæan arrangement of Quadrupeds commences at the first opening on the left-hand of the entrance, where, dispersed on rocks and the branches of a large Orange-tree, are about sixty species of the genus Simia; consisting of Apes, Baboons, and Monkeys. It is difficult to determine the species of many of them, and others are not yet described by any Naturalist; those known are numbered, and will be found as follows: 


\section{MONKEYS.}

1. The Barbary Ape, or Magot. (S. Inuus.) Is a morose, ill-natured animal, but by means of severity may, in a state of captivity, be made to perform a number of actions, which surprise us by their near approach to those of man.

2. The Pig-tailed Baboon. (S. Nemestrina.) Is a native of Sumatra, and is very familiar and gentle in its behaviour towards strangers, but appears melancholy in a state of captivity.

3. Variegated, Tufted, or Ursine Baboon. (S. Mormon.) This Baboon is very numerous about the Cape of Good Hope, and is one of the largest of this tribe of animals, measuring, when full grown, nearly five feet in height. It is very strong, fierce, and libidinous, yet at the same time is capable of attachment and gratitude. One that was sent to me in the year 1803, had two deep wounds in his loins, owing to the pressure of a heavy chain by which he was confined; on appearing anxious to examine the wounds, it readily presented the lacerated part for inspection, and after one side was dressed with a very sharp mixture (though at the same time it was agonized with pain) it opened the other wound for the same application, which it continued to do until such time as the excoriated places were healed. It remained at the $\mathrm{Mu}$. seum some time afterwards, and although mischievous to the family, yet, on the least motion of my hand, or on my uttering an angry word, it was all attention and submis. sion. These Baboons in their native country do considerable damage to the gardens and plantations, carrying on their depredations in large troops, with such boldness and resolution as excite astonishment.

4. Ribbed-nose Baboon. (S. Maimon.) Is about two feet from the nose to the tail; it is an active and sprightly animal, greatly resembling the above Baboon, but not so large, nor are the colours so bright; it is equally playful, but not so malignant.

The French naturalists have made this the young of the 
former, and from the change I have observed in those of different ages, I have no doubt of their being right.

5 and 6. Lion-tailed Baboon, male and female. Siliens.) These are very remarkable and highly extraordinary animals: they are natives of Ceylon and other parts of India, and are, in their native state, wild, ferocious, and mischievous: the female lived many years in the menagerie of her Royal Highness the Duchess of York, who presented it to the Museum.

7. Wood Baboon. (S. Silvatica.) An active, roving species, inhabiting the woods of Africa.

S. Crested Baboon. (S. Cristata.) A native of India.

9. Dog-faced Baboon. (S. Hamadryas.) A very large and fierce species, remarkable for the long grey hair with which it is covered; it is rarely brought to Europe; it is a native of the hottest part of Africa, where it is said to be found in vast troops, and to be very fierce and dangerous. This was brought from Arabia by Lord Valentia.

10. Green Monkey. (S. Sabrea.) A most gentle, playful creature, inhabiting several parts of Africa and India; in its native regions it is said to be of a beautiful green colour, which fades to an olive grey soon after its arrival in this country.

\section{The Mustache. (S. Cephus.) Inhabits Guinea.}

12. White-ezelid Monkey. (S. Ethiops.) A native of Madagascar, gentle and diverting in its manners.

13. The Chinese Monkey. (S. Sinica.)

14. White-nosed Monkey. (S. Petaurista.) A native of Guinea, only thirteen inches high ; tail twenty inches long. An entertaining, gentle animal, showing great attachment to the person who feeds it.

15. The Negro Monkey. (S. Maura.) From Africa.

16. Palatine Monkey. (S. Rolaway.) This beautiful and gentle animal was brought from the Slave Coast in Africa; its colour appeared to have changed much on its being confined, as the rich bay on the inside of the limbs 
was turned to a yellowish white; its singular white beard gave it, whilst living, an air of great gravity, and its manners were quite inoffensive and mild. It died in the collection of $\mathrm{Mr}$. Polito, in the winter of 1808 , owing probably to the severity of the weather.

\section{Long-nosed Monkey. (S. Nasau.)}

18, 19, and 20. Three species of the Long-armed, Four-fingered, or Spider Monkey. (S. Paniscus.) One of these was received from South America in the summer of 1808 , and lived for some time. In general, its appearance was extremely disgusting; the arms were of an extraordinary length, and the hands destitute of all ap. pearance of thumbs; the tail is also of a great length, and is bare for a considerable way near the tip, by means thereof it could reach any thing as well as with its hands. The whole animal, except the face, hands, and end of the tail, is covered with long coarse black hair, thinly disposed, except on the head, where it grew forward in the same manner as the human species, giving to its mulattocoloured face the appearance of a miserably wretched old man. Its disposition was extremely gentle and inoffensive, but so timid, as never to be familiar; if held by the hands, it uttered a doleful cry, and frequently tear's ran from its eyes, but it never showed the least inclination to bite.

21. A white variety of the above.

22. Royal Monkey. (S. Seniculus.) Is a native of Cayenne, and is sometimes called the Preacher or Howler, from the custom of their assembling together, and making a most horrible noise in the woods.

23 and 24. Fearful, or Rivg-tailed Monkey. (S. Trepida.) A native of Guinea; and of a lively disposition: is frequently kept in France.

25 and 26. Varieties of the above.

27 and 28. Male and female of the Squirrel Monkey. (S. Sciurea.) This is one of the smallest and most beautiful of the monkey tribe; it is a native of South America, and with difficulty kept alive in this country. 
29. Fox-tailed Monkey. (S. Pithecia.) The hair of this singular animal is very long, and of a dark brown, or nearly black colour; it is about the size of a large cat; is a native of Guinea, and is said to be very fierce in its disposition.

30. Several specimens of the Siriated Monkey, or Sanglin. (S. Jacchus.) This extraordinary little animal, no larger than a Squirrel, is an inlabitant of Brazil. In a native state these Monkeys are supposed to feed upon fruits, but in a state of confinement they will occasionally feed on insects, snails, \&c. Edwards, in his Gleanings, makes mention of a pair of these animals, which belonged to a London merchant, who resided at Lisbon; they had young at that place. These, at their birth, were exceedingly ugly, having no fur: they would frequently cling fast to the teats of the dam; and when they grew a little, used to hang upon her back and shoulders. When she was tired, she would rub them off against the wall, or whatever else was near, as the only mode of ridding herself of them. On being forced from the female, the male immediately took them to him, and suffered them to hang round him, to ease her of the burden. Her Royal Highness the Duchess of York has lately succeeded in breeding these diminutive and delicate little animals.

31 and 32. The Great-eared Monkey. (S. Midas.) About the size of a Squirrel; the colour black, except the lsands and feet, which are orange. It is a native of Cayenne and Brazil.

Red Monkeys, male and female. (S. Rubra.) They are natives of Senegal and the hottest parts of Africa; are a harmless and playful species.

\section{LEMUR. (MAU CAU COS.)}

THESE are placed on the branch of a tree, near the third window. They are generally mild and gentle in their disposition, and inhabit the warmer parts of India.

1. Slow Lemur, or Tailless Maucauco. (Lemur Tar- 
diradus.) It is about half the size of a cat, and is a native of the coast of Coromandel. According to the pleasing description of the late learned Sir Wm. Jones, in the 4th volume of Asiatic Researches, its manners are gentle and interesting; it sleeps during the day, and feeds on fruits.

2. Woolly Lemur, or IMongoz. (Lemur Mongoz.) About the size of a cat, and a native of Madagascar; it feeds on fruits, and in a state of captivity is sportive and harmless.

3. The Potto. (Lemur Potto.) This is an inhabitant of Guinea.

4. Ring-tailed Lemur, or Maucauco. (Lemur Catta.) This is a very beautiful, gentle, harmless, and entertaining animal, frequently kept tane by ladies; it is a native of the warmer parts of India, and feeds on fruit, which it eats sitting upright, holding it in its fore paws. The young ones were lately bred in this country.

5. Little Maucauco. (Lemur Minutus.) Is about the size of a mouse, an elegant little animal, and bears a strong resemblance to the monkey tribe; it is the only specimen known in England.

Dr. Shaw has figured a small Lemur in the 14th volume of the Naturalist's Miscellany, but it is much larger, and destitute of the mane, so conspicuous in this species.

\section{BATS. (VESPERTILIO.)}

THESE are placed in front of the Lion's den, opposite the entrance.

Madagascar, or Vampyre Bat. (VespertilioVampyrus.) This uncommon animal is called, by Buffon, the Rousette; it measures upwards of three feet from the tip of one wing to the other; the body is nearly as large as that of a cat, but it resembles a rat in the shape of the head; it is covered with short hair of a reddish brown colour; the top of each wing is armed with a strong claw, with which it fastens itself to the branches of trees; it has likewise 
five sharp claws on each foot. Some of those animals grow to an enormous size; and in the islands of the East Indies they are sometimes seen in such numbers, that they darken the air at noon-day; they are carnivorous, and very ferocious. In a scarcity of flesh and fish, they feed on vegetables and fruits of every kind. This is the Bat to which Linnzus applied the title of Vampyre, on the supposition of its being the species of which so many extraordinary accounts lave been given relative to its power of sucking the blood of men and cattle. Such is the account of authors who have described it.

In the autumn of $1810 \mathrm{I}$ had, for a short time, a living one of a large size, from the East Indies, and, contrary to what has been asserted, found it a most inoffensive, harmless, entertaining creature; it refused animal food, but fed plentifully on succulent fruits, preferring figs and pears, and licked the hand that presented them, seeming delighted with the caresses of the persons who fed it, playing with them in the manner of a young kitten; it was fond of white wine, of which it took near half a glass at a time, lapping it like a cat. This had a very evident effect on its spirits, as it then became extremely frolicsome and diverting, but never once attempted to bite. It slept suspended, with its head downwards, wrapping its satinlike wings rounds its body in the form of a mantle. I several times permitted it to enclose the end of my little finger in its mouth, for the purpose of observing if it would attempt to draw blood, but not the slightest indication of such intention appeared, and I have strong reason to doubt the stories related so greatly to its disadvantage.

Madagascar Bat, with the wings closed.

The long-eared Bat. (Vespertilio Auristus.) This is one of the most common English Bats, and may be frequently seen, during the summer evenings, pursuing the various insects on which it feeds.

Near this is a white variety of this animal, in which the delicate and admirable structure of the wings is finely shown. 
The Great Bat. (Vespertilio Noctula.) The largest of the British species.

The Horse-shoe Bat with its young; taken in the Abbey Church, Bristol, where it is very common. (Vespertilio Ferrum Equinum.)

\section{SLOTH. (BRADYPUS TRYDACTYIUS.)}

THREE of these are on the stem of the American Alue, near the head of the Rhinoceros.

These are of all quadrupeds the most slothful and indolent. "Nature (says the Count de Buffon) seems to have created this ill-constructed mass of deformity for nothing but misery." They have neither canine nor incisive teeth; their eyes are dull and heavy; their mouth wide and thick; their fur resembles dried grass; their thighs are almost disjointed from their haunches; their legs are very short and badly shaped; they have no soles to their feet, nor toes separately moveable: but only two or three claws, excessively long, crooked downwards and backwards. They can neither seize on prey, nor feed on flesh, and are therefore reduced to live on leaves and wild fruits. They take up a long time in crawling to a tree, and are still longer in climbing to its branches. When at last one of them has accomplished its end, it fastens itself to a tree, crawls from branch to branch, and by de. grees strips the whole of its foliage; in this manner it remains several weeks without moistening its food; and when it has consumed its sture, and the tree is left quite naked, unable to descend, it continues on till hunger presses, which becoming more powerful than the fear of danger, or even death itself, it drops to the ground, without being capable of exerting any effort to break the vio. lence of the fall. Its manners are sluggish to an excessive degree; its general appearance disgusting; its voice plaintive, piteous, and even horrible. It can live a prodigious time without food: Kircher says forty days. It has vast strength in the paws, and fastens its claws into any thing with such force, that they cannot be disengaged: 
hence, when beasts of prey attack this animal, it adheres to them so strongly, that they are both found dead in each other's grasp.

\section{ANT-EATERS. (MYRMECOPHAGA.)}

THESE are placed next the Monkeys, near the model of one of the turrets or nests of the Termites, or White Ants of Africa, which are often of the height of ten feet, appearing at a distance like the villages of the natives.

The Ant-eaters are destitute of teeth, but have protruding snouts, through which they draw the insects which form their food on their long clammy tongues.

The Great Ant-eater, or Tamanoir. (Myrmecophaga Jubata.) This is the largest of the Ant-eaters, as well as the most singular in its appearance; it is upwards of six feet in length, and has a very slender snout, out of which it protrudes its worm-like tongue into the nests of ants, on which it feeds. It is a native of South America, from whence one was some years since brought alive to Spain: it was fed on raw meat, cut small, of which it ate four or five pounds a day.

The Cape Ant-eater. (M. Capensis.) Though the former is called the largest of this remarkable family, yet this may be considered the heaviest, as its weight sometimes exceeds $100 \mathrm{lb}$. It burrows in the ground, and sleeps by day.

Little Ant-eater. (M. DidactyIa.) Inhabits Guinea, and the hottest parts of South America. They climb trees in quest of a species of ant that builds its nest among the branches; they thrust out their clammy tongues into the nest, and draw them into their mouths covered with insects. Their tail is of great use to them in climbing, as they twist it round the branches to prevent their falling.

Middle Ant-eater. (M. Tetradactyla.) Inhabits South America, goes out in the night, and sleeps during the day; when irritated, it seizes on a stick or other object with its fore claws, and fights sitting on its hind legs; the extre- 
mity of the tail is naked and prehensile, by means of which it is enabled to suspend itself to the branches of trees.

Porcupine Ant-eater. (M. Aculeata.) Shaw's Zoology, vol.i. page 175. This is one of those curious animals which have been lately discovered in New Holland; it differs from all the other Ant-eaters in having the body covered with sharp spines, resembling porcupines' quills, only they are shorter and thicker in proportion. It has a remarkably long, tubular snout, with a very small mouth, out of which it shoots its tongue, in the same man. ner as the others. It burrows under the ground with the greatest ease, nature having furnished it with amazing strength in its legs and feet.

Another Porcupine Ant-eater; it varies from the above in the lightness of the colour of the spines, and in their being shorter, and more covered with stiff whitish hair; it is probably of a different sex, or a younger animal.

The Manis, or Scaly Ant-eaters, are placed with the last, to which they have a strong affinity, except the covering of the body, which in these is strong horn-like seales.

Pangolin, or Short-tailed Manis. (Manis Pentadactyla.) A remarkably fine specimen of this extraordinary and highly curious animal, measuring five feet in length; it is a native of Africa and India, and its principal food is the white ant, against the united attacks of which nature has given its impenetrable coat of armour. It was brought to this country by Mr. Samwell, surgeon, who was with Captain Cook during his voyages of discovery.

Long-tailed Manis. (M. Tetradactyla.) This rare animal is a native of India and Africa. It is perfectly gentle and harmless, though it has the most formidable appearance, being entirely covered with large sharp scales, which it erects when irritated. Buffon says, "The most cruel and voracious of beasts, such as the Tiger and the Panther, make but useless efforts to devour these armed 
animals; they tread upon and roll them, but when they attempt to seize them, are grievously wounded; they can neither terrify them by their violence, nor crush them by their weight."

Another specimen of this singular animal, near it, differs in having double the number of scales, which are only half the size.

Near the above are two specimens of the nine-banded Armadillo, with a young one, and one of the eightbanded. It receives the name of Armadillo, or Hog in Armour, from the Spaniards, and from the impenetrable coat of mail with which it is furnished by nature for its defence. It is a native of South America, where there are several kinds; but the principal difference consists in the number of bands or folds, of which the armour that covers the body is composed. It is a harmless, inoffensive animal, feeds on roots, herbs, and other vegetables, grows very fat, and is much esteemed for the delicacy of its flesh. The Indians hunt it with small dogs, trained for the purpose: when it is surprised, it runs to its hole, or attempts to make; a new one, which it does with great expedition, having strong claws on the fore feet, with which it adheres so firnly to the ground, that if it should be caught by the tail, whilst making its way into the earth, its resistance is so great that it will sometimes leave its tail in the hands of its pursuers; to avoid this the hunter has recourse to artifice, and by tickling it with a stick, it gives up its hold, and suffers itself to be taken alive. If no other means of escape be left, it rolls itself up within its covering, by drawing in the head and legs, and bringing the trail round them, as a band to connect them more forcibly together; in this situation it sometimes escapes by rolling itself over the edge of a precipice, and generally falls to the bottom unhurt.

Next to these is the huge Rhinoceros (Rhinocerns Unicornis), which may be considered as one of the most powerful of animals; in strength, indeed, it is inferor to none, and its bulk (says Bontius) equals the Elephant, but it is less in stature, on account of the shortness of its legs. The length of the Rhinocerus, from head to tail, is usually twelve feet; and the circumference of the body nearly 
equals that length: its nose is armed with so hard and formidable a horn, that the Tiger will rather attack the Elephant, whose proboscis he can lay hold of, than the Rhinoceros, which he cannot face without danger of hav ing his bowels torn out by the defensive weapon of his adversary. The body and limbs of the Rhinoceros are covered with a skin so hard and impenetrable, that he fears neither the claws of the Tiger, nor the trunk of the Elephant. It is said to turn the edge of a scimitar, and to resist even the force of a musket-ball. The upper lip of the Rhinoceros is capable of great extension, and is so pliable that the animal can move it from side to side, twist it round a stick, collect its food, or seize with it any thing it would carry to its mouth. 'The Rhinoceros, without being ferocious or carnivorous, is totally untractable and rude: it seems at times to be subject to paroxisms of fury. The one which the King of Portugal sent to the Pope in the year 1513 , destroyed the vessel which transported it. Like the hog, the Rhinoceros wallows in the mire, is a solitary animal, and delights to rove near the banks of rivers. It is found in Bengal, Siam, or China, and other countries of the East, where it feeds on the grossest herbs, preferring thistles and shrubs to the finest of pasturage. The female produces but one at a time, which during the first month exceeds not the size of a large dog: at the age of two years, the horn is not more than an inch long; at six years old, it is ten inches long, and grows to the length of three feet. From the peculiar construction of the eyes, the Rhinoceros can only see what is immediately before him. When he pursues any object, he proceeds always in a direct line, overturning any thing in his way. His sense of smelling is so acute, that his pursuers are obliged to avoid being to windward of him: they follow him at a distance, aud watch till he lies down to sleep; they then approach and discharge their muskets into the lower part of his belly.

A fine specimen of the Elephant. (Elephas Maximus). This stupendons animal lived for many years in Exeter 'Change, and was remarkable for its docility and obedi- 
ence to its keeper. For a further description of this identical animal, see "Wonders of Animated Nature," just published, p. 111 .

Close to the Elephant commence those animals denominated by Linnæus, Fera, which contain all the beasts of prey.

1. In a low den is the Wolf from Hudson's Bay. (Canus Lupus). It is of an unusual size, and the colour is lighter than in those of Europe.

2. The Striped Hyana. (C. Hyæna.) A young animal from the Cape of Good Hope, little more than half its full size.

3. The Jackal. (C. Aureus.) These inhabit the warm parts of Asia and Barbary, prowling by night, sometimes in flocks of two hundred together, hunting in concert : at the cry of one, all within hearing howl prodigiously, and urge other beasts to hunt the Stag, whilst the Lion or Tiger, lying in wait, seize the prey, and tirst satisfying themselves, leave the remainder to the Jackals; from whence originates the tale of their being the Lion's provider.

4. The Barbary Jackal. (C. Barbarus.)

5. Cape Jackal. (C. Mesometes.)

6. Black Fox. (C. Lycaon.) This animal inhabits the colder parts of America, and is said to be the most crafty of its tribe; its skin is also of the greatest value, as fur.

7. The Arctic Fox. (C. Lagopus.) In its summer dress.

8 and 9. Ditto in its winter clothing. These inlabit the most northern parts of America, frequent the sea shore, and occasionally feed on shell-fish. 


\section{FELINE TRIBE.}

IN dens, and on the large rocks facing the entrance, are disposed the whole of the Feline tribe, containing the most cruel and rapacious of animals.

1. In a cavern is the Lion (Felis Leo), and near its feet sleeping on the ground, a Cub about four months old.

2. The Panther. (Felis Pardus.) Is seen issuing from a den : it is an untameable animal, and next in size to the Tiger. It inhabits Africa, Barbary, the remotest parts of Guinea, and the interior of South America; is extremely fierce, and attacks every living creature without distinction, but happily prefers the flesh of brutes to that of mankind. The ancients were well acquainted with these animals. The Romans drew prodigious numbers from Africa, for their public shows. Scarus exhibited 150 of them at one time; Pompey 410; and Augustus 420. They probably thinned the coast of Mauritania of these animals; but they still swarm in the southern parts of Guinea. The skin of the Panther was presented by Mr. Polito.

3. The Jaguar. (F. Onca.) Is a most fierce and destructive animal, in its manner resembling the Tiger. It is an inhabitant of South America.

4. Walking on the top of the rock, above the Lion's den, is the Hunting Leopard. (F. Jubata.) This animal was received from Senegal, and was perfectly tame, having never been subject to confinement. In India they are trained for the taking of game: three living ones were shown a few years since in the Tower, that were part of a pack belonging to the late Tippoo Sultan. This animal has not retractile or sheated claws, like the rest of the feline tribe.

5. The Black Leopard. (F. Discolor.) This was of a most untameable and ferocious temper, which it constantly exhibited, not even distinguishing the person that fed it from others. It is said to be an inhabitant of Java, 
6. The Puma, or American Lion, with its young. (F. Concolor.) This is the largest of the American beasts of prey, sometimes measuring five fect from the nose to the insertion of the tail. It is an animal of great strength and fierceness, sometimes climbing trees, and springing at whatever may pass beneath. 'The young were produced at Exeter 'Change, and are remarkable for the spots with which they are covered whilst in a state of infancy.

7. Margay, or Tiger Cat. (F. Tignina.) This diminutive species has all the evil propensities and appetites for rapine of the Tiger; it resides principally on trees, preying on birds. It is a native of South America.

8. The Serval. (F. Serval.) Was received from Senegal; it likewise inhabits India and Thibet, residing mostly on trees and avoiding man, unless when enraged.

9. Cinerous Cat. This animal appears to have been described only by Mr. Pennant. It is a native of Senegal, and its disposition is not so fierce as the generality of its kind.

10. The Persian Lynx. (F. Caracal.) Was received from Senegal. It is sometimes tamed and used in the chase of the smaller quadrupeds; also of Herons, Cranes, Pelicans, \&x.

\section{American Lynæ. (F. Lynx.)}

Art the end of the rocks on which the above are placed, follow the

\section{VIVERRA, OR WEASEL GENUS.}

1. The Ichneumon. (Viverra Ichneumon.) In India, but still more in Egypt, the Icheumon has always been considered as one of the most useful and estimable of animals; since it is an inveterate enemy to serpenis, rats, and other noxions creatures which infest those regions. In India it attacks with courage that most dreadful reptile the Cobra de Capello, or Hooded Snake. It also diligently 
seeks for the eggs of Crocodiles; for which reason, as well as for its general usefulness in destroying all manner of troublesome reptiles, it was held in such a high degree of veneration by the ancient Egyptians, as to be regarded as a minor deity, or one of those benevolent beings proceeding from the Parent of the universe. For the purposes above specified, it is still domesticated by the Indians and Egyptians in the same manner as the Cat in Europe; and it has also the merit of being easily tamed, and performing with alacrity all the offices of that creature. Like many others of this tribe, it is a most dangerous enemy to several animals larger than itself, over which it gains a victory, and sucks their blood. In a wild state it frequents rivers in quest of prey, where it is reported to swim and dive like an Otter, and continues a length of time under water. As it is a native of warm climates, it of course is greatly injured by a removal to the cold regions of Europe, to the variations of which it generally falls a victim.

2 and 3. The Coati Mondi, or Brasilian Weasel. (V. Nasua.) A native of South America. They may easily be domesticated. One that I kept a considerable time was so familiar, that it was with difficulty it could be kept from ascending to my shoulders, and when I was present would at any time attack any strange dog that approached his apartinent. It afterwards conceived a strict friendship, which continued till death, for a Longarmed Monkey (Simia Paniscus): they were inseparable companions; but I suspect the object of attraction was the warmth they received from each other in keeping close together.

4. Striated Weasel. (V. Putorius.) It is a native of North America, and remarkable for the intolerable stench which it emits when irritated, which is so powerful as to prevent either men or dogs from pursuing it : even the clothes of persons who are near it are obliged to be buried in the ground for some time before they can be purified.

5. The Slcunk. (V. Mephites). This animal, like the last, defends itself by emitting so intolerable an odour, as 
to overpower whatever pursues it; this sometimes hapo pens in the houses of the settlers in North America, when their whole stock of provisions is rendered useless.

6. The Civet. (V. Civetta.) This Cat is sometimes erroneously called the Musk Cat. It is a native of the hottest climates of Africa and Asia; yet it is capable of living in temperate or even in cold countries, if it be carefully defended against the injuries of air, and provided with delicate and succulent food. The Civet Cat is a wild fierce animal, and feeds on its prey in the same manner as the Fox. In Holland they are frequently reared for the sake of their perfume, which greatly resembles musk. This is produced in a pouch under the tail; and those that keep them for this purpose put them into a long narrow box, in which they camnot turn; this box is opened behind twice or thrice a week by the person who collects the perfume, who drags the animal backwards by the tail, and keeps it in that situation by placing a bar before it, while with a small spoon he scrapes the odoriferous substance from the pouch in which it is produced.

7. Three-striped Weasel. (V. Hermaphrodita.) It is a native of Barbary, and very destructive to poultry.

8. The Genet. (V. Genetta.) This beautiful little animal was kept for some time alive, and was suffered to play at liberty in the house: in some parts of the East it is domesticated, and is very useful in clearing the houses of vermin.

\section{9 and 10. Spotted Fitches. (V. Maculata.) Of New Holland.}

11. The Otter. (Mustela Lutra.) Is pretty generally diffused over Europe, North America, and Asia, as far as Persia; it feeds principally on fish, and is very destructive to our ponds and rivers; it lives in holes under ground, the openings to which are beneath the surface of the water. The bite of the Otter is extremely severe, but they are capable of being tamed, and taught to fish for their owners, which they do with the greatest address, as they are capable of remaining a considerable time under water. 


\section{The Pekan. (M. Canadensis.)}

13. The Martin. (M. Foina.) Inhabits the woods of most parts of Europe, feeding on birds, and other small animals.

14. Pine Martin. (M. Martis.) Is occasionally found in the pine forests in the northern parts of our island.

\section{Fisher Weasel. (M. Nigra.)}

16. The Stoat, or Ermine: (M. Erminea.) Is found principally in the wilds of Russia, and other cold conntries. It is from the shin of this animal that the valuable white fur is made. They are said to change their colour, being brown in summer, and white in winter.

On a tree near these is Ursus Gulo. (The Glutton.) A voracious animal, inhabiting the northern parts of Europe, Asia, and America: it preys on deer, hares, and the smaller quadrupeds, frequently concealing. itself among the branches of trees, from whence, springing on the shoulders of whatever passes, it adheres firmly to them till they drop from fatigue or loss of blood. Their skins are valuable as fur.

\section{OPOSSUMS.(DIDELPHIS.)}

$\mathrm{NEAR}$ the farthest corner from the entrance are placed the Opossums. (Didelphis.) Till the discovery of New Holland, most of the then known animals of this genus were natives of America. Australasia has, however, added more new species to this extraordinary family than were before known: they are most remarkable for the abdominal pouch with which the females are furnished, which can be opened or shut at pleasure, in which the young are concealed in time of danger.

1. Virginiun Opossum. (D. Opossum.) Inhabits the warmer parts of America, climbs trees, and springs from branch to branch by means of its strongly prehensile tail.

2. The Marmose. (D. Murina.) 
3. New Holland Opossum. (D. Caudivolva.) Has been brought alive to this country, and is a pleasing, cleanly animal.

4. and 5. Kangaroo. (D. Gigantea.) Of all the curious animals which the vast Island, or rather Continent of Australasia has presented to our view, the Kargaroo must be considered as one of the most exiraordinary; its size, general conformation, teeth, and other particulars, conspiring to render it a most interesting object to every naturalist. The first discovery of this remarkable quadruped was in the year $177($, when Captain Cook was stationed on the Coast of New Holland. It is the only quadruped our colonists have vet met with in New South Wales that supplies them with animal food. There are two kinds; the largest that has been shot weighed about $140 \mathrm{lb}$. and measured from the point of the nose to the end of the tail six feet one inch; the tail two feet one inch; head eight inches; fore leg one foot; hind legs two feet eight inches; circumference of the fore pat of the body near the leg one foot one inch; and of the hind part three feet. The smaller linds seldom exceed 6olb. This animal is furnished with a pouch similar to that of the Opossum, in which its young is nursed and sheltered. It feeds on grass and other vegetable substances. In their native state these animals are said to feed in herds of thirty or forty together; and one is generally observed to be stationed, as if apparently on the watch, at a distance from the rest. One of the most remarkable peculiarities of the Kangaroo is the extraordinary faculty which it possesses of separating at pleasure, to a considerable distance, the two fore teeth in the lower jaw. The Kangaroo may be considered in some degree as naturalized in England, several having been kept for many years in the royal domains at Richmond, which have during their residence there produced young, and promise to render this most elegant animal a permanent acquisition to our country.

6. The Bush Kangaroo. Not described by any writer. 
7 and 8. Kangaroo Rats. (D. Tridactyla.) This species, which, from its colour and the general aspect of its upper parts, has obtained the title of the Kangaroo Rat, is about the size of a Rabbit; the general shape of the animal resembles that of the Kaligaroo, but it is far less elegant, the proportion of the parts less pleasing, and the hair, which is a dusky cinerous brown, of a coarser nature. In its teeth it ayrees with the great Kangaroo, except that it has eight instead of six front teeth in the upper jaw, the two middle ones being sharp-pointed: the fore teeth in the lower-jaw are like those of the Kangaroo as to shape and position, but are smaller in proportion; the grinders are three in number on each side, both above and below, the foremost being fluted or channelled with several longitudinal ribs; the two remaining ones plain. The structure of the hind feet in this species resembles those of the Kangaroo, but the fore feet have only four toes. The female is furnished with an abdominal pouch for the reception of the young. Some of this species were imported in a living state from New Holland, and brought forth young, Its native name is Poto Roo.

\section{The Porcapine Opossum. (D. Obesula.)}

\section{Spotted Opossame. (D. Maculata.)}

11 and 12. Flying Opossus. (D. Volans.) These are natives of New Holland, and Dr. Shaw seems to speak of them as the most beautiful of quadrupecis. Their general appeirance is that of a large Flying Squirrel, to which they are viearly allied.

\section{1\%. A white variety of the above.}

13. Squirrel Opossam. (D. Sciurea.) Is a beautiful animal, greatly resembling the former, except in size.

14. Zebra Opossem. (D. Cynocephala). This animal, which is the only one known in any collection, is a native of Van Diemen's Land, where it lives among the caverns and rocks in the high and almost impenetrable glens of the mountainous parts of that country: it is the largest carnivorous animal yet discovered in New Holland, mea- 
suring from the nose to the end of the tail five feet three inches; it is said to be extremely voracious, which will scarcely be doubted, when it is known that the one described in the ninth volume of the Linnæan Transactions, p. 179, had in its stomach the partly digested remains of the Porcupine Ant-eater; it is said to have a short guttural cry, and to appear exceedingly inactive and stupid.

15. Pigmy Opossum. (D. Pygmæa.) Th is is the least of all the Opossums; and is not larger than a com. mon Mouse: it is a native of New Holland.

\section{WOMBA'1.}

THE Wombat is a native of New Holland. A living one was brought to this country by Mr. Brown, librarian to the Linnzean Society, who went as a naturalist with Captain Flinders, on his voyage of discovery; it lived in a domesticated state for two years in the possession of Sir Everard Home, to whom, in a paper read to the Royal Society, June 23, 1808, we are indebted for the following observations:- "It burrowed in the ground whenever it had an opportunity, and covered itself with earth with surprising quickness; it was quiet during the day, but constantly in motion in the night; was very sensible to cold ; it eat all kinds of vegetables, but was particularly fond of new hay, which it ate stalk by stalk, taking into its mouth like a Beaver, by small bits at a time; it was not wanting in intelligence, and appeared attached to those to whom it was accustomed, and who were kind to it; and when it saw them it would put its fore paw on the knee; when taken up, it would sleep in the lap: it allowed children to pull and carry it about, and when it bit them, did not appear to do it with anger or violence. It appeared to have arrived at its full growth, weighed about twenty pounds, and was about two feet two inches long."

The Brazilian Porcupine. (Hystrix Prehensilis.) This very curious animal measures about two feet six 
inches in length, and is entirely covered, except the tip of the tail, with short, strong, and very sharp spines, of which the largest is about three inches; it lives in woods, and climbs trees, in which it is assisted by its prehensile tail. It is an inhabitant of the warmer parts of South America.-Both the specimens in this collection were kept some time alive in London. Its food was entirely of a vegetable nature, and their manners mild and inoffensive; their voice is a weak, tremulous cry, somewhat resembling that of a young pig, but not so shrill or so lond.

Canada Porcupine. (H. Dorsata.) The spines of this are longer and sharper than the last, but owing to their being covered with long hair, are not visible but on close inspection. This animal sometimes climbs trees, and is killed by the Indians of North America as an article of food; the beautiful ornamental works on their dresses and utensils are executed with the dyed quills of this animal.

\section{CAVY. (CAVia.)}

THESE are all natives of the warmer parts of America; they feed on vegetables, and either burrow in the ground or live in the hollows of trees.

1 and 2. Spotted Cavy. (Cavia Paca.) These animals burrow in the banks of rivers, having three outlets to each dwelling; they are easily tamed, like the common Cavy or Guinea Pig; and their flesh is much esteemed, and eaten by the Portuguese and Spaniards of America.

3. The Long-nosed Cavy. (Cavia Aguti.) Sometimes called the Java Hare, and is frequently imported into this country.

\section{The Rock Cavy. (C. Aperea.)}

5 and 6. River Cavy. (C. Capybara.) It is the largest of the Cavias, and the only one known to have been brought to this country; it lived two years in the possession of Mr. Kendrick, of Piccadilly; was extremely gentle, and fed on vegetables, though in a state of nature they are 
said to dive and catch fish with great dexterity. A singularity in this animal, which has not been noticed by writers, is, that on the outside of each hind foot, it has a large horny projection, four inches long and two broad, probably intended to assist in swimming.

\section{BEAVER.}

The Beaver. (Castor Fiber.) The Beaver is a native of the most northern parts of Europe, Asia, and America; in its natural state it lives in well-regulated societies of from two to three hunured each, constructing their habitations of wood and clay in the most astonishing manner, and with the greatest regularity; but when taken from their native haunts they are said, by all naturalists who have had an opportunity of observing them, to lose their instinct, and become a stupid and sluggish animal. The following anecdote may, however, be relied on :-A pair of them was purchased a few years since by Mr. Polito, for the purpose of exhibiting in his collection; they were put into an upper room or loft, with a quantity of green sticks and boughs for their food; on visiting them in the morning, only one could be discovered, which was lying in a state of evident uneasiness in a corner of the room: at last, after some search, the female was found to have died in the night, and the male had removed her to an obscure part of the place, and covered her carefully over with wood, so that no part of her could be seen, and had then retired to the place where he was found.

\section{MARMOT.}

The Marmot. (Arctomus Marmota.) The Marmot, when taken young, is more capable of being tamed than any other wild animal ; it will easily learn to perform feats with a stick, to dance and obey the voice of its master; it bears a great antipathy to the dog, and when it becones familiar in a house, and is certain of being supported by its master, it will in his presence attack the largest dogs, and boldly fasten on them with its teeth. They are natives 
of the Alps and Pyrennean mountains, and remain in a torpid state from the end of September to the beginning of April. They live in societies, from five to fourteen in number, in burrows which have several passages constructed with great art; the principal apartment at the end is warmly lined with moss and hay; and it is asserted that this work is carried on by the whole company; that some cut the finest grass, others pull it up, others take it n their turn to convey it to the hole; upon this occasion it is added, one of them lies on its back, permits the hay to be heaped on its belly, keeping its paws upright to make room, and in this manner is dragged, hay and all, to their common retreat. Whenever they venture abroad, one is placed as a centinel, sitting on an elevated rock, while the others amuse thenselves in the fields below; and no sooner does he perceive a man, an eagle, a dog, or any other enemy, than he informs the rest by a kind of whistle, and is himself the last to take refuge in the cell. These animals run much swifter up hill than down; they climb trees, and run up the clefts of rocks with great ease: indeed it is ludicrously said of the Savoyards, who are the general chimney-sweepers of Paris, that they have learned their trade from the Marmot.

\section{SQUIRRELS. (SCIURUS.)}

THESE are a numerous and active race of animals, dispersed over most parts of the world; their food is wholly vegetable, of which they lay up stores for their winter provision.

1. The Black Squirrel. (Sciurus Niger.) Inhabits North America, where it does much mischief to the maize plantations.

2. Grey Squirrel. [S. Cinerius.] This is also a native of America, and is so great a pest to the farmer that very considerable sums have been paid for its destruction.

3. Pair of Russian Squirrels. A variety of S. Vulgaris. 
4. Palm Squirrel. [S. Palmarum.] Inhabits the hot parts of Africa and Asia: and feeds principally on cocoa nuts.

5. and 6. Ground Squirrel. [S. Striatus.] A native of the colder parts of America and Asia; burrows under ground, and has cheek pouches, in which it carries home its winter stock of provisions.

7. Flying Squirrel of America. (S. Volucella.) This animal is less than the common European, being not above five inches long, and is of a grey ash colour on the back, and white on the under parts; he has black prominent eyes like a mouse, with a large broad fiat tail. The name seems to imply that he is endowed with wings like a bat, which however is not the case; for he has only a loose skin on each side, extending from the fore to the hinder feet, with which it is connected; this skin he can stretch out like a sail, which holds so much air, that it buoys him up, by which means he can jump from one tree to another at a great distance; insomuch, that some have thought he had the faculty of flying. He feeds on the same provisions as other squirrels, and may easily be made tame; but he is apt to do a great deal of mischief in corn-fields, by cropping the corn as soon as it begins to ear.

8. and 9. An undescribed species from Senegal.

\section{HARES. (LEPUS.)}

\section{American Hare. (Lepus Americanus.)}

2. American Hare, just receiving its winter clothing, which in the northern parts is entirely white.

3. Hare from Senegal, greatly resembling the common, but the hair much shorter and finer, and the animal of a less size than ours.

4. Angora Rabbit. (L. Angorensis.)

The Lama. (Camelus Glama.) This animal is a narive of the Peruvian mountains, and was the only beast 
of burden known to the original inhabitants: it resembles the Camel in being able to abstain from drink for a considerable time, and it travels about three Grerman miles a-day, carrying a burden of $150 \mathrm{lb}$. This specimen was about six months old; bred in $18 \mathrm{i} 1$, by 1 . Thorpe, Esq. of Chippenham Park, near Newmarket, and is the only one ever produced in this country.

The Vicuna. (C. Vicuna.) This is another of the Peruvian animals, with which, till lately, we have not been well acquainted. It inhabits the highest mountains of the Andes in flocks; is timid and gentle, but very swift: it carries small burdens, although it is not easily tamed; their wool is extremely fine; from it is manufactured cloths of the most exquisite softness and beauty, known by the name of Vigonia cloth. This specimen is the only one ever brought alive to this country; it was in the extensive menagerie of Mr.S. Polito, to whose liberality in encouraging the importation of foreign animals the public are indelbted for the knowledge of many interesting subjects before unknown.

The Memina, male and female. (Moschus Memina.) These were received from Java; one of them lived some time in the menagerie of her Royal Highness the Duchess of York, who presented it to the Museum. The other was presented by her Royal Highness the Princess Charlotte of Wales.

The Stag: (Cervus Elephus.) A remarkable fine specimen of this noble animal; presented by the Earl of Derby, in whose park at Knowsley it led the herd for several years.

\section{CAMELOPARDALiS.(GirafFA.)}

The Camelopardalis, or Giraffa. (Camelopardalis Giraffa.) Which is by far the tallest of all known quadrupeds, measuring the extraordinary height of seventeen feet three inches from the hoof of the fore foot to the top of the head, whilst (so disproportionate is the form) that 


\section{4}

the body scarcely exceeds that of a horse. Till lately the existence of so wonderful an animal was doubted by many European Naturalists, who ranked it amongst the fabulous monsters of antiquity.

This specimen was lately killed at a considerable distance, in the interior of the Cape of Good Hope, by the Rev. Mr. Edwards, an African Missionary, when travelling in that country under the patronage of Lord Caledon, then Governor of the Cape. It is represented as an harmless timid animal, living in small herds of six or seven together, in the plains that border on Caffraria: they are so extremely shy and wary, that it is with the greatest difficulty they can be approached: they feed on the fruit of the wild apricot, and on the tender branches of several species of Mimosa. This specimen, which is a full grown male, and very rich in colour, is allowed to be the finest ever brought to Europe, and is in the most perfect preservation.

Such is the excessive rarity of this singular animal, that from the decline of the Roman Empire till the middle of the eighteenth century its existence was deemed extremely problematical, if not in the highest degree chimerical. The contradictory accounts of Oppian, Heliodorus, and Strabo, at periods when curiosity night have been amply gratified, and investigation have received the fullest and most satisfactory conviction, by attending the public games (upon which occasions, Piiny informs us, it was frequently exhibited), were alone sufficient to create justifiable doubts, and propagate an opinion of the inaccuracy of the statements and inadvertency of these writers upon the subject. The narratives of succeeding travellers, who felt little inclination to observe, or whose opportunities of observation were limited and few, only tended to increase this perplexity, already too intricate, and by their dark anbiguous details, equally opposite and vague, to confirm the previous supposition of its fabulous and imaginary origin.

That this conjecture should have been strengthened by a perusal of the several relations of our travellers and naturalists, ought not to excite surprise, when we remember we are told, by one, that the length of its fore-legs is 
double that of those behind--by another, that this disparity does not exist-by a third, that such is their astonish. ing height, that a man mounted on horseback may with ease pass beneath its body-and by a fourth, that in point of magnitude, it does not exceed the size of a small horse.

From such a contrariety of evidence, the veracity of the traveller became disputed, and the credulity of the naturalist an object of derision. The whole was rejected as a fictitious invention-was classed with the crude abortions of Pliny's fervid imagination; and such was the influence of this variety of testimony, that though Captain Carteret had given a distinct account of a Giraffa killed at the Cape of Good Hope in the year 1769, Mr. Pennant still refused to yield his assent, till convinced by personal inspertion of a skin preserved in the University of Leyden. 'The cloud of uncertainty, however, which has so long hovered over the real form of this beautiful and extraordinary animal, has of late years been dissipated by the minute descriptions of Gordon, Vaillant, and Sparrman. From them we have learned its size, its proportions, and peculiarities, with an accuracy and fidelity both laudable and decisive. Yet, whilst we are fully acquainted with the external qualities of the Giraffa, it is to be lamented we know so little of its habits. An extreme docility, and remarkable passiveness of disposition, form the prominent features of its character. Antonius Constantius, a writer of the fifteenth century, and one of the earliest of modern travellers who has noticed it, mentions one which he saw led through the streets of Fano, so gentle and quiescent in its conduct, that the children of the town brought bread and fruit, which it patiently ate from their hands, and received the gratuitous offerings of the spectators at their windows as it passed. Mr. Gordon also records an anecdote of the Giraffa slain by himself, which represents it in a truly amiable and interesting light. Having wounded it with a musket-ball, it suffered him to approach it as it lay upon the ground, without offering to strike with its horns, or showing any inclination to revenge itself. $\mathrm{He}$ even stroked it over the eyes several times, which it only closed without evincing any signs of resentment. When its throat was cut, for the purpose of procuring the skin, 
and whilst lying in the agonies of death, it struck the earth with its feet, with a degree of violence and force far exceeding that of any other animal. In these, $\mathrm{M}$. Vaillant informs us, lay his only means of defence; yet such is the rapidity with which he is enabled to exert them, that the succession of their movements almost escapes perception; and so powerful are the blows inflicted, that they are sufficient to repel the attacks of the Lion, though of little avail against the fury and impetuosity of the Tiger.

Its general food consists of the leaves of a species of Mimosa, called by the natives kanaap, and by the planters kamel doorn; though when grass is to be obtained (which from the scarcity of pasture in the southern provinces of Africa is but seldom), in common with other horned cattle, it joyfully partakes of such a repast. An erroneous opinion, however, has been promulgated, that when feeding upon shrubs and herbage, it is compelled to extend its legs to a consirierable distance, in order to bring its mouth in contact with the earth. This, M. Vaillant, who has been peculiarly explicit upon the subject, contradicts from his own experience and observation, both whilst grazing and drinking, and pertinently remarks, that if we compare the length of the neck with that of the legs and body, we shall discover there is no necessity for this unnatural assistance. This testimony is also confirmed by the representation given of the Giraffa in the beautiful Prrestine pavement of Sylla, where we observe it delineated amidst a herd of African quadrupeds, browsing in the customary posture of other beasts.

\section{ANTELOPE. (ANTILOPES.)}

1. The Blue Antelope. (Antilope Leucophoea.) Was received from Senegal; it is also found at the Cape of Good Hope.

2. Corrine Antelope. (A. Corina.)

3. Female of the above. 
4. The Harnessed Antelope. (A. Scripta.) A most beautiful species, found near the Senegal river. Presented by his Royal Highness the Duke of York.

5. Pigmy Antelope: (A. Pygmaea.) This beautiful and diminutive species is only nine inches high. It inhabits the hotter parts of Africa, and is said by authors to be capable of leaping a wall twelve feet high; it is easily tamed, but is so tender as not to survire a removal from its native clime.

The Broad-tailed Sheep. A curious African species, sent by the Dey of Algiers to the Earl of Liverpool, who presented it to the Museum.

The Musk Ox. (Bos Moschatus) is an inhabitant of the mountains of North America, where it is found in herds, in which the number of females greatly preponderate. They are said to be very fierce, and to run and climb the mountains with great rapidity.

The Zebra. (Equus Zebra.) This extremely beautiful animal is a native of the hotter parts of Africa, and is frequently seen in herds in the neighbourhood of the Cape of Grood Hope; they are however so extremely wild and cautious as rarely to be taken, and are of a disposition so vicious and untameable as seldom to submit to the bridle, even when taken young. In size the Zebra is superior to the Ass; in its colour it is much more elegant: the ground is white or cream colour, and the whole animal is decorated with very numerous black or brown stripes, disposed with the utmost symmetry in a manner not easily to be described.

The Pecari, or Mexican Hog. (Sus Tajasu.) Inhabits the warm parts of America, feeding on vegetables and reptiles: is said to attack and devour the Rattlesnake with impunity. 
On a Rock, near the Sel view, are placed

\section{THE SEALS.}

Thr Common Seal. (Phoca Vitulina.) This animal is a. native of the European Seas, and is found about all the coasts of the Northern hemispheres, and even as far as the opposite one, being seen in vast numbers about the southern polar regions. We are informed by Mr. Pennant, that it also inhabits some fresh-water lakes, as that of Baikal, Aral, \&c. Seals may often be observed sleeping on the rocks near the coast; but when approached too near, they suddenly precipitate themselves into the water.Sometimes they sleep sound; and it is affirmed by some, that the Seal sleeps more profoundly than most other quadrupeds. The structure of the Seal is so singular, that, as Buffon well observes, it was a kind of model on which the imagination of the poets formed their tritons, sirens, and sea-geds, with a liuman head, the body of a quadruped, and the tail of a fish. The Seal is possessed of a considerable degree of intelligence, and may be tamed so as to become familiar. The female Seals produce their young in the winter season, and seldom bring more than two at a birth. It is said that they suckle their young ones for about the space of a fortnight on the spot where they are born, after which they take them out to sea, and instruct them in swimming and seeking their food, which consists of fish, sea-weeds, \&c.

Falkland Isle Seal. (Phoca Australis.) Remarkable for the structure of the hind-feet, the webs of which extend far beyond the claws, which in the fore-feet are wanting.

A small Seal from Davis's Straits, supposed to be Phoca Pucilla.

Near this, on the right-hand side, is seen, as descending from a rock, the White, or Grenland Bear (Ursus Maritimus.) This is a far larger species than the common Bear, and is said to have been sometimes found of the length of twelve feet. The heal and neck are of a more lengthened form than in the common Bear, and the body 
itself is longer in proportion. The whole animal is white, the ears are round and small, the eyes little, and the teeth of extraordinary magnitude; the hair is of great length, and the limbs are extremely large and strong. It seems confined to the coldest part of the globe, being found within eighty degrees of north latitude, as far as any navigators have yet penetrated. The shores of Hudson's Bay, Greenland, and Spitsbergen, are its principal places of residence; but it is said to be carried sometimes on the floating ice as far south as Newfoundland. The Polar Bear is an animal of tremendous strength and fierceness. Barentz, in his voyage in search of a northeast passage to China, had proof's of the ferocity of these animals in the island of Nova Zembla, where they attacked the seamen, seizing them in their mouths, carrying them off with the greatest ease, and devouring them in the sight of their comrades. It is said that they sometimes will attempt to board armed vessels at a distance from shore, and have been repelled with difficulty. Presented by S. Staniforth, Esq. of Liverpool.

On one of the basalt columns near the sea, is the Platypus, (Anatinus Platypus.)

Of all the quadrupeds yet known this seems the most extraordinary, exhibiting the perfect resemblance of the beak of a duck engrafted on the head of a quadruped; so great was the resemblance, that Dr. Shaw, who published the first account of it, could scarcely refrain from thinking it a deception; but we are since become acquainted with the animal and its habits. It is a native of New Holland, and is found in fresh-water lakes in the neighbourhood of Port Jackson, in the muddy banks of which it procures its food. Governor Hunter observed a native spear one with great dexterity; but it used its sharp claws with such strength, that it was necessary to confine it between two boards in order to extract the barb, when it ran off with greater speed than from the structure of the fore-feet it seemed capable of doing on the land.

Near the Zebra is perhaps the largest specimen of the Land Tortoise ever brought into this country, the shell alone measuring three feet two inches in length, and near. 
six feet in circumference; it is the Testuda Indica of Linnæeus.

Twisted round the trunk of the large tree behind the Zebra, is a specimen of the Great Serpent of Surinam; and on the ground, with its head erect, near the window opposite the Stag, is another from the Brazils; presented by his Royal Highness the Duke of York: they are nearly twenty feet long, and are of the kind that has usually been called the Boa Constrictor.

On the rocks, near the commencement on the land side, is the Coryphene or Dolphin.

The Torpedo Ray. (Raja Torpedo.)

Frog Fish. (Lophius Europæus.)

\section{Young Shark.}

Near these are a pair of those immense shells, the Chama Gigas of Linnceus. They are the largest of all known shell-fish, being three feet across, and weighing upwards of three hundred pounds. This is the Cockle mentioned by voyagers as capable of dining a whole ship's company. The fish is said to weigh forty pounds; it is black, but not ill-tasted, and is generally cut into steaks and broiled. 


\title{
BO'TANICAL SUBJECTS
}

\author{
im \\ PANTHERION。
}

Through the windows on the left side of the entrance is a fine specimen of Citrus Aurantium, the Seville Orange.

O11 entering the room on the same side, forming the division of the first and second windows, is Artocarpus Incisa, the Bread-fruit tree.

The fruit of this tree the inhabitants of the Ladrone, Philippine, and most of the islands in the South Seas, use as bread. Dampier says, that in Guam, one of the Ladrone islands, there is a certain fruit, called the Breadfruit, growing on a tree as big as our large apple-tree, with dark leaves. The fruit is round, and grows on the boughs like apples, of the bigness of a good penny loaf: when ripe it turns yellow, soft, and sweet; but the natives take it green, and bake it in an oven till the rind is black; this they scrape off, and eat the inside, which is soft and white like the inside of new-baked bread, having neither seed nor stone; but, if kept longer than twentyfour hours, it is harsh. This fruit is in season eight months in the year, and the natives feed on no other sort of bread during that time.

Somewhat to the right of the foregoing, at a distance from the window, is the Agave Americana, American Aloe, in bloom.

The next division of the windows is formed by Citrus, the five-tingered Lemon, or Citron, an agreeable acid fruit, which is used by the inhabitants of hot climates for the same purposes as the common lemon. 
Fronting the third window is Musa Sapientum, the Banana. This plant is to the inhabitants of the West India islands what the Bread-fruit tree is to the countries where it is indigenous, the staple article of food: the fruit is so essential to the natives of tropical climes, that they never go to a distance without taking a quantity of it with them. "When the West Indians undertake a voyage, they make a provision of paste of Banana, which in case of need serves them for nourishment and drink; for this purpose they take ripe Bananas, and having squeezed them through a fine sieve, form the solid fruit into loaves, which are dried in the sun or in hot ashes, after being previously wrapped up in the leaves of the Indian Flowering Keed.'

When they make use of this paste they dissolve it in water, which is very easily done, and the liquor, thereby rendered thick, has an agreeable acid taste imparted to it, which makes it both refreshing and nourishing.

Twining round the stem of the Banana, is the Passiflora Quadrangularis, the Square-stalked Passion-flower. This is the only species producing an edible fruit, which in the West Indies is known by the name of Granadilla.

The stem dividing the third and fourth windows is the Annona Reticulata, Custard-apple. This, with two other species, are frequently confounded under the appellation of sweet and sour sop.

Placed between the Rhinoceros and Elephant, is the $\boldsymbol{D i}$ mocarpus Litchi, which produces a beautiful strawberrylike fruit.

At a short distance to the right is a variety known by the name of Mandarin Orange; when ripe it has a peculiar fine flavour, and has the appearance of being double.

Trained on the fourth window is a curious variety of Peach, which is cultivated in China, on account of its luscious fruit.

Trailing on the rocks over the den of the lion, is the Bottle Gourd, a native of the West Indies.

Projecting, as from the back of the room, is seen the Fruit of Adansonia Digitata, the Boabab. This is one of the largest of the vegetable tribe, being (as we are in- 
ormed) sometimes found exceeding seventy feet in circumference; the leaves as well as fruit are used by the Negroes for food: the latter they dry and then pound; after which they mix the powder with their drink, which in some measure allays the violent perspirations that frequently prove dangerous in hot climates.

From the centre division is seen a fruit known to the Chinese by the name of Date.

The two centre window-frames and divisions are formed of a branch of Quercus Ruber, the Cork Tree.

In the adjoining window, is a small branch of Passiflora Alata, the Wing-stalked Passion-flower.

Nearly opposite the centre of the same window, is the Carica Papaya, the Papaw-tree, with its fruit in different stages of maturity.

The division of the next window, is the Psidium Pyriferum, the Guava, or Bay-plum, a fruit frequently imported into this country in the form of a jelly, from the West Indies.

In the background, to the right of the Papaw, is the Borassus Flabelliformis, the Palmira Fan, or Malabar Palm. From this plant the natives of India obtain a very agreeable liquor susceptible of vinous fermentation, from which they either distil a spirit, or by evaporation obtain sugar. The leaves of this and other species are used by the inhabitants of Asia and Ceylon as paper, requiring no other preparation than to be separated and cut smouth with a knife; they are written upon while fresh with a steel, or stylus; the characters thus traced are rubbed over with charcoal or other black substance, which gives them the distinctness of engravings. The wood of this tree is of a dark colour, elegantly veined with yellow, and is used for buildings and domestic purposes. The leaves are also used for umbrellas, one of which, Thunberg asserts, "is sufficiently large to shelter six persons from rain."

In front of the last is the Urania Speciosa, an interesting and highly curious plant, nearly approaching in external appearance the Strelitzia and Helliconia.

Behind this, towards the corner, is Pandannus Odo- 
ratissimus, the Nicobar Bread-fruit. This, though of so tempting an appearance, is but very indifferent food, and is seldom eaten but in cases of necessity.

Behind the Pandannus is Citrus Decumana, the Shaddock, the fruit of which was cast from recently imported specimens.

At a few paces to the right is Cocos Nucifera, the Cocoa-nut tree. This well-known tree rises to the height of sixty feet; is crowned with a bunch of ten or twelve leaves, each leaf being from ten to fifteen feet in length, and composed of a double range of flag-shaped leaflets: the cocoa is of slow growth, but, to compensate for this, it lives long, and regularly bears fruit three or four times in the year. In Ceylon it is a common practice to make an incision in the flower-sheath, from whence issues a white sweet liquor of a pleasant flavour, which the natives call Toddy. This distils from the wound, and is received in earthern pots or chatties, which are suspended from the branches.

It is a wholesome and cooling drink, while fresh, but this state does not continue long, as it contains a quantity of sugar, and of course, in the warm climate of Ceylon, it soon ferments; in the space of twenty-four hours it becomes acid, and after a time proves intoxicating. The fruit of this tree is the cocoa-nut so generally known in this country; when half ripe, it contains a quantity of clear water, better known by the name of milk; this has a pleasant smell and most agreeable taste: in countries where the heat is intense, and the ground frequently parched for want of moisture, the milk of this nut proves, from its coolness, a delightful and refreshing beverage.

Every part of this tree is destined for the service of man: of the rind of the nut the natives make their cordage and nets; of a light loose substance, that grows among the branches, cloth of various kinds, and for various purposes is manufactured; the branches and stems are used in buildings and for domestic purposes, while the leaves are employed to cover the roofs and repel rain : these last are also made into mats, baskets, and other domestic utensils. 
Embracing the stem of the Cocoa, is a beautiful variegated species of Gourd, cast from a specimen raised in this country.

Fronting the last window on this side, is a beautiful and high-flavoured, though diminutive, species of Orange, modelled from a drawing in the possession of Sir Joseph Banks, whose unbounded liberality in forwarding scientifie inquiry, the Proprietor of this Establishment has gratefully to acknowledge; as, from Sir Joseph's persomal directions, the use of his library and valuable collection of fruit, the principal part of these curious exotic vegetables was modelled.

On the stem, dividing the two last windows, is Mangifera Indica, (the Mango) the fruit of which is well known in this country as a pickle.

Fronting the Camel-leopard, is Areca Catechu, (the Betel-tree) whose fruit is in this country known by the name of betel-nut, and used here as a dentifrice; it grows in clusters at the top of the stem, in the manner of the cocoa ; these nuts are about the size of a hen's egg, and the natives chew them in the same manner as tobacco is used in this and other countries.

The nuts are prepared by first cutting them in slices, and sprinkling them with slacked lime, and then wrapping them in leaves of some species of pepper, which they masticate with the nut. The wood is used in building the habitations of the natives. In America the trunks of the trees are used as water-pipes, for which purpose they are admirably adapted, from the hardness and durability of the wood.

The Passion-flower, climbing the tree, is of the same species as the one already described with the Banana.

Continuing to the right, is Thea Viridis, (the Greenmost plat) which is now pretty generally cultivated in neat conservatories and green-houses in this kingdom.

Growing from behind the trunk of the large tree in the corner, is the Mimosa Scandens, (Climbing Mimosa.) The immense pods or seed-vessels are hanging pendent from a small branch; in one of the small windows fronting the sea-view, a pod is placed, which serves to show 


\section{6}

the exact form: it is not a large specinen, as they are frequently met with full four feet in length.

From the last-mentioned window is seen Rhizophora Gymnorhiza, the Mangrove, or Oyster-tree. This is a native of the East Indies, where it attains the height of ten or twelve feet; it grows in moist situations, generally within the influx of the sea, where the tide can wash its stem. There is something exceedingly curious in the manner which nature has chosen to conduct the seed of the Mangrove into the earth; it is a remarkable deviation from the general rule, and is simply this:-The fruit produces a single seed, inclosed in an oblong capsule, which, when ripe, begirs to germinate without falling from the tree. A little radicle makes its appearance from the top of the capsule, from whence it proceeds, in the form of a ligneous fibre, till it is more than a foot long; in this state the seed hangs pendent, till by its weight, added to the continual oscillations to which it is subject from the slightest breath of air, it is disengaged from the capsule and falls to the ground. The process which follows is common to other seeds.

The seeds are said to fall so as to rest in a vertical position; this may easily happen where the ground is constantly moist and soft enough to receive any impression, which is constantly the case where these trees are found.

In China, the bark is employed to strike a black dye; it emits a very strong sulphureous exhalation, and the wood, which has the same odour, burns very briskly and with a dazzling flame.

In consequence of the Mangrove growing as it were in the water, it becomes the resort of fishes, particularly oysters; the last deposits its spawn upon the stems and branches, which in time becomes loaded with them; and the oysters gathered from such situations may readily be known by pieces of the wood, which are generally attached to the shells.

From the circumstances above related, the tree has taken the common appellation of Oyster-tree.

Rising on two green stems, are the heads or flowers of 
Cyperus Papyrus, the Papyrus. They are placed rather to the left of the Mangrove.

From this plant the ancient Egyptians formed their books or papers. For this purpose the thick part of the stalk was cut in two; the pellicle between the pith and the bark, or perhaps the two pellicles, were stripped off and divided by an iron instrument, which was probably sharp-pointed, but did not cut at the edges. This was squared at the sides, so as to be like a ribband, and then laid upon a smooth table, after being cut the length the leaf required.

The Egyptians applied the Papyrus to several purposes, independent of the manufacture of paper. The roots sometimes served them for fire-wood, and were formed into different domestic utensils. Of the stems, interlaced together, they constructed a kind of boat, and of the interior bark they made their sails, mats, clothes, cordage, and coverlids of their beds.

The boats made of Papyrus resemble great baskets, compactly woven together, and are plastered with some resinous substance. It was probably in a vessel of this kind that Moses was exposed, when he was found by the daughter of Pharaoh on the banks of the Nile.

For the above, and other interesting accounts of the botanical subjects in this Exhibition, we are indebted to WOOD's Zoography.

Fis.

Whiningham and Rowland, Irinters, Gorwchl Stcet, Lobndon. 



\section{EXHIBITIONS}

AT THE

\section{EGYPTIAN HALL,}

PICCADILLY, LONDON.

\section{ROMAN GALLERY.}

THE celebrated and magnificent Picture, 26 feet long, of the Judgment of Brutus upon his Sons, painted by the President of the Academy of Rome, and removed from the Louvre in June, 1814, is now open for exhibition in the superb Roman Gallery, erected for its reception at the Egyptian Hall, Piccadilly. Besides the commanding interest which this elaborate work of art must excite, the furniture and decorations of the gallery claim unusual attention; the exquisite Mosaic floors of the Baths of Nero, and other rare and curious articles of antiquity, (recently brought from the Louvre and Malmaison, for the purpose) embellish this classic apartment; a descriptive account of which, in general, and of this great picture in particular, is just published, with an Eтching, price One Shilling.

\section{BUONAPARTE's CARRIAGE.}

A separate apartment contains the Military CARRIAGE OF BUONAPARTE, captured after the battle of Waterloo; and which has been removed hither from the King's Mews, by an order of Government, together with the horses of the Ex-Emperor by which it was drawn; the gold and silver necessaire, his personal wardrobe, \&c. This carriage, together with its costly contents, was 
brought to England by the officer who took it; and has been already visited by sixty-five thousand persons. The coachman of Napoleon, who was with the carriage, when takell, having suffered amputation of his arm, and recovered from the other numerous wounds he received, is now in England, and attends in the room with the carriage, the exhibition of whicli will shortly close.

\section{Admission to each exhibition One Shilling.}

Descriptive Catalogues of each may be had at the Egyptian Hall, Piccadilly.

Mr. BuLlock has the honour of submitting to the Nobility and Public the arrangement he has made for an Establishment of real importance to science, and of eminent advantage to individuals. For this purpose he has completed a magnificent suite of Apartments, one hundred and twenty feet long, on the ground floor of the Egyptian Hall, in Piccadilly, designed for the reception, exhibition, and sale, by commission, of every article connected with the Fine Arts, Antiquity, and Natural History: thereby to facilitate the wishes of those who are forming collections, as well as the views of those who seek remuneration for interesting objects which they have procured, or ingenious works which they have executed. Among the various departments that will be formed, the Picture Gallery, just erected for the purpose, will command particular attention. This Apartment, from its connection with the Museum, which is visited by most strangers in the Metropolis, must possess considerable advantage over any other establishment of a similar nature. Valuable curiosities of every description (subject to the approbation of the Proprietor) are allowed to remain on sale for one season, without expense, unless actually sold, when 10 per Cent. will be cluarged on the amount.

Egyptian Hall, Piccadilly. 


Special

$$
\begin{gathered}
90-B \\
29429
\end{gathered}
$$


